\title{
Use of a Watershed-Modeling Approach to Assess Hydrologic Effects of Urbanization, North Fork Pheasant Branch Basin near Middleton, Wisconsin
}

Water-Resources Investigations Report 01-4113
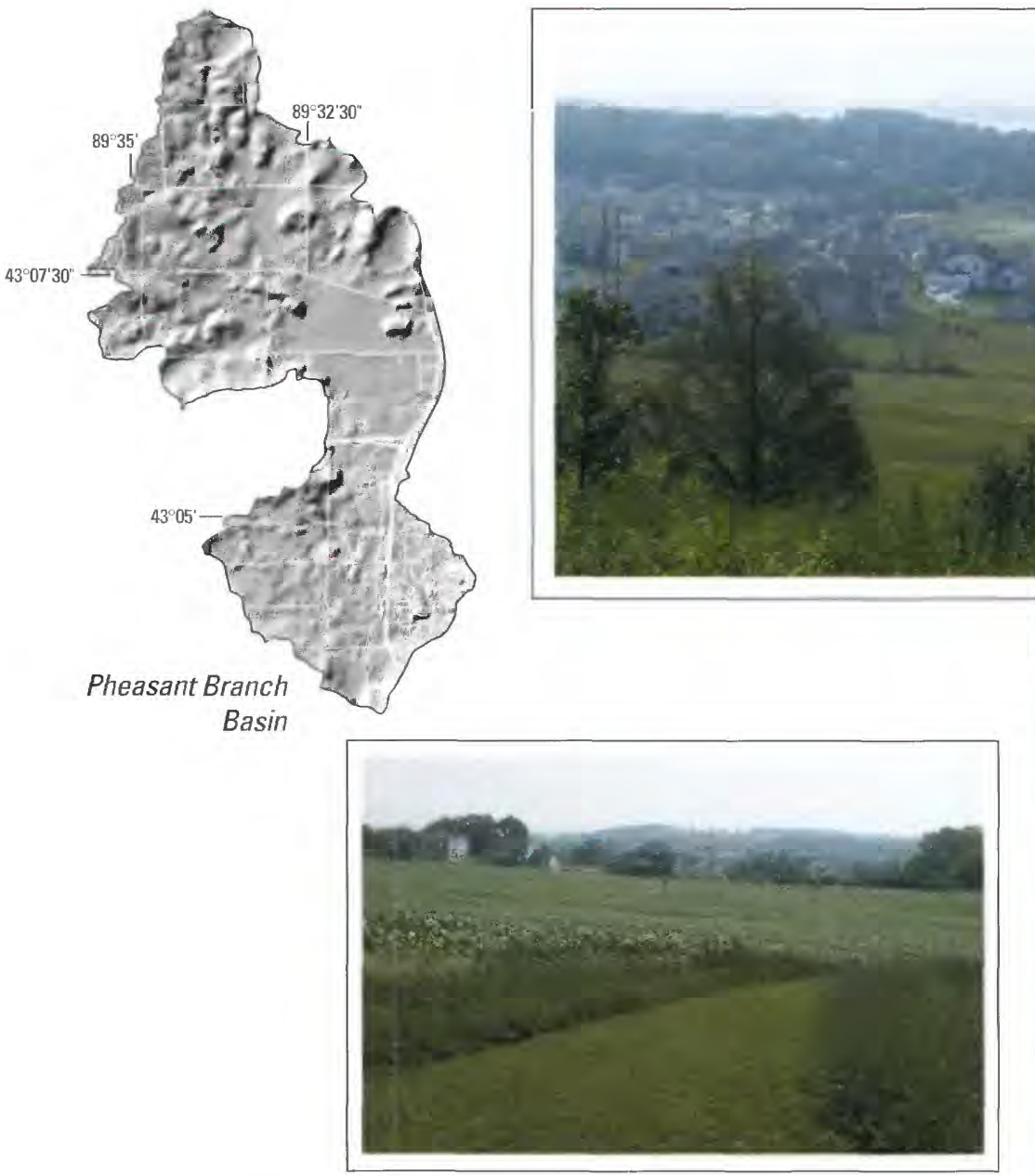

Prepared in cooperation with the

City of Middleton

Wisconsin Department of Natural Resources

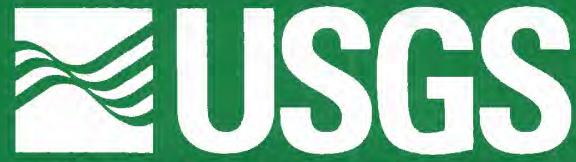

science for a changing world
Average annual basin water budget (inches), water years 1993-98

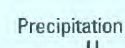

35.2

2.8

Overland flow

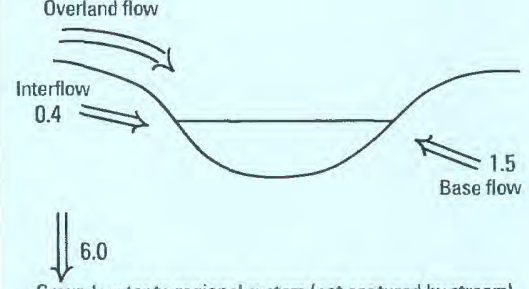

Ground water to regional system (not captured by stream)

(4.8 in. over basin) Model simulated streamflow $\underline{5.2}$ cubic feet per second (4.9 in. over basin) Measured streamilow $\underline{5.3}$ cubic feet per second Marsh springs 2.1 cubic feet per second

Budget not balanced because of change in ground-water storage. 



\section{Use of a Watershed-Modeling Approach to Assess Hydrologic Effects of Urbanization, North Fork Pheasant Branch Basin near Middleton, Wisconsin}

\section{By J.J. Steuer and R.J. Hunt}

U.S. GEOLOGICAL SURVEY

Water-Resources Investigations Report 01-4113

In cooperation with the

CITY OF MIDDLETON

WISCONSIN DEPARTMENT OF NATURAL RESOURCES

Middleton, Wisconsin

2001

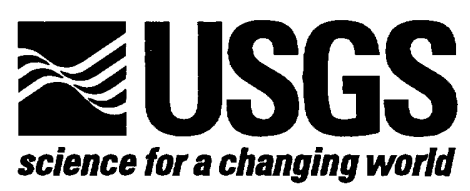




\title{
U.S. DEPARTMENT OF THE INTERIOR \\ Gale A. Norton, Secretary
}

\author{
U.S. GEOLOGICAL SURVEY
}

Charles G. Groat, Director

The use of firm, trade, and brand names in this report is for identification purposes only and does not constitute endorsement by the U.S. Government.

District Chief

U.S. Geological Survey

8505 Research Way

Middleton, WI 53562-3586
U.S. Geological Survey

Branch of Information Services

Box 25286

Denver, CO 80225-0286 


\section{CONTENTS}

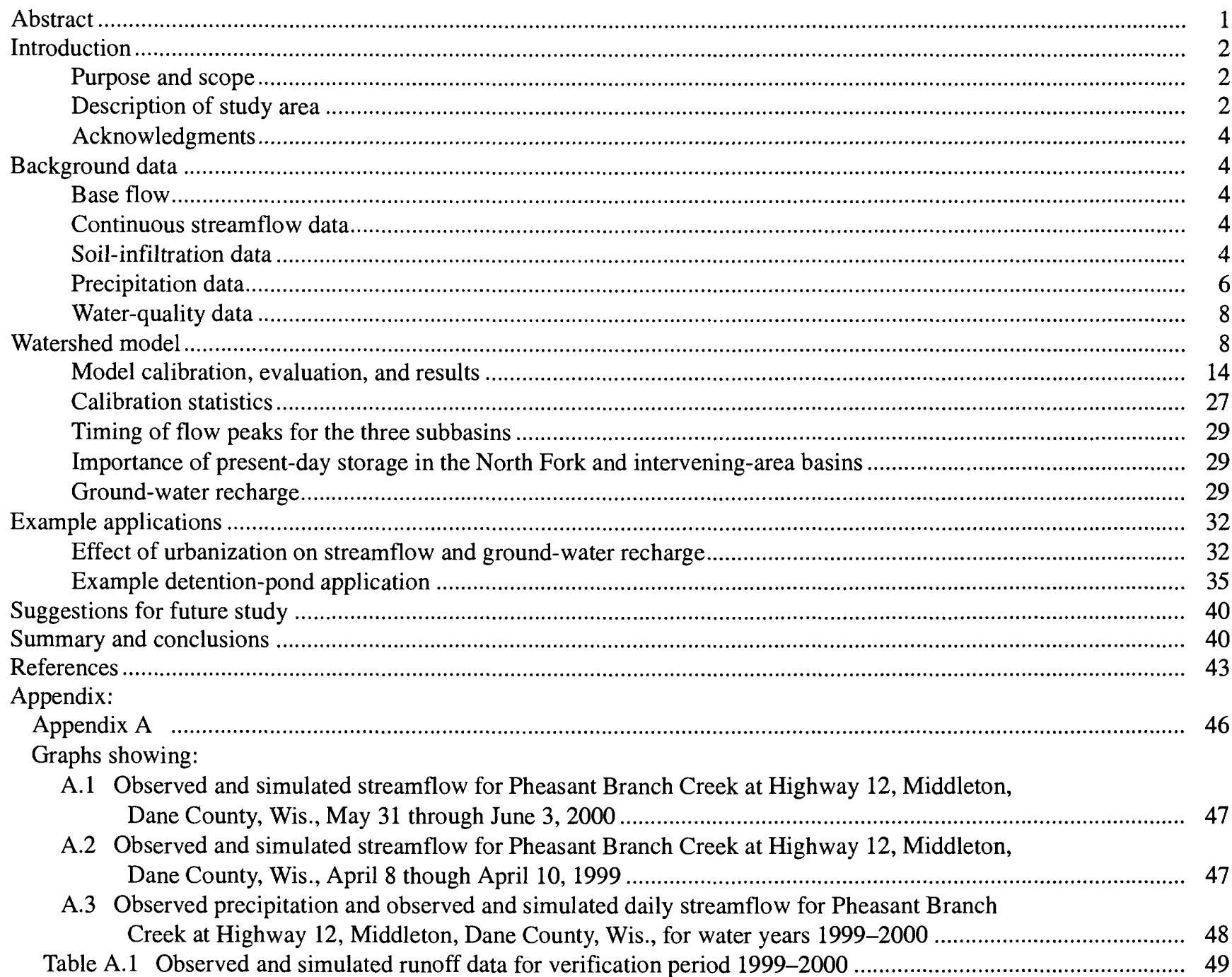

\section{FIGURES}

1. Map showing location of study area, stream-gaging stations, rain gages, and storage sensors, Pheasant

Branch Basin near Middleton, Dane County, Wis.

2-6. Graphs showing:

2. Double-ring infiltrometer results at six sites for a combination of land use and soil types, Pheasant Branch

Basin near Middleton, Dane County, Wis.

3. Event precipitation and average precipitation at the six rain-gage sites in Pheasant Branch Basin near Middleton, Dane County, Wis., from February 1998-August 1998

4. Annual loads of total suspended sediment and total phosphorus for Pheasant Branch Creek at

Highway 12, near Middleton, Dane County, Wis., water years 1989-99.

5. Pheasant Branch Creek streamflow at Highway 12, near Middleton, Dane County, Wis., and associated

loads of phosphorus and suspended sediment, from February 1998 through August 1998

6. Cumulative streamflow, phosphorus loads, and suspended-sediment yields for Pheasant Branch Creek subbasins, near Middleton, Dane County, Wis., February 1998 through August 1998

7. Schematic diagram of the Precipitation-Runoff Modeling System (PRMS). 


\section{FIGURES-Continued}

8-9. Maps showing:

8. Hydrologic response units (HRUs) used in daily mode simulations, Pheasant Branch Basin near Middleton, Dane County, Wis.

9. Channel network, flow planes, impervious area, and reservoirs used in the storm-hydrograph simulations, Pheasant Branch Basin near Middleton, Dane County, Wis.

10-17. Graphs showing:

10. Observed and simulated annual runoff for Pheasant Branch Creek at Highway 12 near Middleton, Dane County, Wis., 1993-98.

11a. Observed precipitation and observed and simulated daily mean streamflow for Pheasant Branch Creek at Highway 12, near Middleton, Dane County, Wis., for water years 1993-95

11b. Observed precipitation and observed and simulated daily streamflow for Pheasant Branch Creek at Highway 12, near Middleton, Dane County, Wis., for water years 1996-98

12. Simulated annual water fluxes for Pheasant Branch Creek at Highway 12, Middleton, Dane County, Wis., 1993-98.

13. Observed and simulated monthly streamflow volumes for Pheasant Branch Creek at Highway 12 and the North Fork Basin, Middleton, Dane County, Wis.

14. Observed and simulated storm-event streamflow volumes for Pheasant Branch Creek at Highway 12 and the North Fork Basin, Middleton, Dane County, Wis.

15. Observed and simulated storm peaks for Pheasant Branch Creek at Highway 12, Middleton, Dane County, Wis.

16. Observed stage and simulated streamflow for the ephemeral Capitol View Road tributary, Pheasant Branch Basin, Middleton, Dane County, Wis.

17. Observed and simulated streamflow volumes for three small North Fork tributaries north of Schneider Road, Pheasant Branch Basin, near Middleton, Dane County, Wis.

18. Map showing observed and simulated streamflow in the northern basin from April 15-16, 1998, Pheasant

Branch Basin near Middleton, Dane County, Wis......

19-21. Graphs showing:

19. Observed Pheasant Branch Creek streamflow for the North and South Fork Basins and Highway 12, near Middleton, Dane County, Wis., for a range of storm events in 1998

20. Simulated inflow and outflow for the flood-plain storage areas (reservoirs) near Airport Road, Middleton, Dane County, Wis., July 5-6, 1993

21a. Average annual computed recharge in all hydrologic response units in the Pheasant Branch Creek watershed model

$21 \mathrm{~b}$. Monthly precipitation, monthly recharge and surface runoff as calculated for a nondeveloped

(pervious) area and a developed, low-infiltration-rate (impervious) area, 1993-98

22. Map showing simulated capture zone in the lower bedrock capture zone for Frederick Springs, Dane County, Wis. 34

23. Diagram showing simulated and observed average annual water fluxes, in inches, for present-day (1993-98)

conditions, Pheasant Branch Basin upstream from Highway 12, Middleton, Dane County, Wis

24. Graphs and diagrams showing changes in storm peaks, storm volumes, and water fluxes resulting from model-simulated urbanization scenarios A and B as compared to present-day current land use, Pheasant Branch Basin, Middleton, Dane County, Wis., 1993-98.

25-26. Maps showing:

25. Selected North Fork subbasin soil types and simulated channel streamflow volumes for the July 4-13, 1993, high-flow event, scenario A, Middleton, Dane County, Wis.

26. Location of high-infiltration-rate subsoils and three reservoirs used in the example application, Pheasant Branch Basin, Middleton, Dane County, Wis.

27-28. Graphs showing:

27. Simulated inflow and outflow for the Highway $\mathrm{K}$ example detention pond for urbanization scenario A, Pheasant Branch Basin, near Middleton, Dane County, Wis.

28. Simulated Pheasant Branch Creek flow peaks for present-day conditions, urbanization, and urbanization tempered with three detention ponds with 90 degree V-notch weirs, Middleton, Dane County, Wis. 


\section{TABLES}

1. Summary of Pheasant Branch Creek dry-weather gain-loss streamflow measurements as a percentage of Highway 12 streamflow, Pheasant Branch Basin near Middleton, Wisconsin

2. Gaging stations in the Pheasant Branch Basin, the drainage areas, and minimum, mean, and maximum streamflow, near Middleton, Wisconsin

3. Selected properties for five soil types located in the Pheasant Branch Basin near Middleton, Wis

4. Water volumes, phosphorus loads, and suspended-sediment loads during February 1-August 31, 1998, in Pheasant Branch Basin near Middleton, Wisconsin

5. Hydrologic response unit (HRU) parameters and general description for the rainfall-runoff model simulation of the Pheasant Branch Basin near Middleton, Wisconsin

6. Observed and simulated annual runoff data for model simulation, Pheasant Branch Basin near Middleton, Wisconsin

7a. Annual water budget and change from 1993 to 1998 for present-day conditions and two urbanization model-simulation scenarios, Pheasant Branch Basin near Middleton, Wisconsin

7b. Maximum instantaneous streamflow and change from 1993 to 1998 for present-day conditions and two urbanization model-simulation scenarios, Pheasant Branch Basin near Middleton, Wisconsin 


\section{CONVERSION FACTORS AND OTHER ABBREVIATIONS}

\begin{tabular}{|c|c|c|}
\hline Multiply & By & To Obtain \\
\hline \multicolumn{3}{|c|}{ Length } \\
\hline $\begin{array}{r}\text { inch (in.) } \\
\text { foot (ft) } \\
\text { mile (mi) }\end{array}$ & $\begin{array}{l}25.4 \\
0.3048 \\
1.609\end{array}$ & $\begin{array}{l}\text { millimeter } \\
\text { meter } \\
\text { kilometer }\end{array}$ \\
\hline \multicolumn{3}{|c|}{ Area } \\
\hline $\begin{array}{r}\text { acre }(\mathrm{A}) \\
\text { square foot }\left(\mathrm{ft}^{2}\right) \\
\text { square mile }\left(\mathrm{mi}^{2}\right)\end{array}$ & $\begin{array}{l}0.4047 \\
0.09290 \\
2.590\end{array}$ & $\begin{array}{l}\text { hectare } \\
\text { square meter } \\
\text { square kilometer }\end{array}$ \\
\hline \multicolumn{3}{|c|}{ Volume } \\
\hline $\begin{array}{r}\text { liter }(\mathrm{L}) \\
\text { cubic foot }\left(\mathrm{ft}^{3}\right) \\
\text { acre-foot } \\
\text { cubic foot per second-day }\end{array}$ & $\begin{array}{r}0.2642 \\
7.4805 \\
325,851 \\
646,000\end{array}$ & $\begin{array}{l}\text { gallon } \\
\text { gallon } \\
\text { gallon } \\
\text { gallon }\end{array}$ \\
\hline \multicolumn{3}{|c|}{ Mass } \\
\hline $\begin{array}{l}\text { pound } \\
\operatorname{gm}(\mathrm{g}) \\
\operatorname{gm}(\mathrm{g})\end{array}$ & $\begin{array}{c}0.0005 \\
1000 \\
0.00220\end{array}$ & $\begin{array}{l}\text { ton } \\
\text { milligram (mg) } \\
\text { pound }\end{array}$ \\
\hline \multicolumn{3}{|c|}{ Flow } \\
\hline cubic feet per second $\left(\mathrm{ft}^{3} / \mathrm{s}\right)$ & 448.8 & gallons per minute \\
\hline
\end{tabular}

\section{Other Abbreviations:}

cfs cubic feet per second

in/hr inches per hour

in/yr inches per year

$\mathrm{mg} / \mathrm{L} \quad$ milligrams per liter

$\mathrm{mg} / \mathrm{g}$ milligrams per gram 


\title{
Use of a Watershed-Modeling Approach to Assess Hydrologic Effects of Urbanization, North Fork Pheasant Branch Basin near Middleton, Wisconsin
}

\author{
By J.J. Steuer and R.J. Hunt
}

\section{Abstract}

The North Fork Pheasant Branch Basin in Dane County, Wisconsin is expected to undergo development. There are concerns that development will adversely affect water resources with increased flood peaks, increased runoff volumes, and increased pollutant loads. To provide a scientific basis for evaluating the hydrologic system response to development the Precipitation Runoff Modeling System (PRMS) was used to model the upper Pheasant Branch Creek watershed with an emphasis on the North Fork Basin.

The upper Pheasant Branch Creek (18.3 mi 11,700 acres) Basin was represented with 21 Hydrologic Response Units (daily time step) and 50 flow planes (5-minute time steps). Precipitation data from the basin outlet streamflow-gaging station located at Highway 12 and temperature data from a nearby airport were used to drive the model. Continuous discharge records at three gaging stations were used for model calibration. To qualitatively assess model representation of small subbasins, periodic reconnaissance, often including a depth measurement, was made after precipitation to determine the occurrence of flow in ditches and channels from small subbasins. As a further effort to verify the model on a small subbasin scale, continuous-stage sensors (15-minute intervals) measured depth at the outlets of three small subbasins (500 to 1,200 acres).

Average annual precipitation for the simulation period from 1993 to 1998 was 35.2 inches. The model simulations showed that, on average, 23.9 inches were intercepted by vegetation, or lost to evapotranspiration, 6.0 inches were infiltrated and moved to the regional ground-water system, and 4.8 inches contributed to the upper Pheasant Branch streamflow. The largest runoff event during the calibration interval was in July 1993 $\left(746 \mathrm{ft}^{3} / \mathrm{sec}\right.$; with a recurrence interval of approximately 25 years).

Resulting recharge rates from the calibrated model were subsequently used as input into a ground-water-flow model. Average annual recharge varied spatially from 2.3 inches per year in the highly impervious commercial/industrial area to 9.7 inches per year in the undeveloped North Fork Basin with an average overall recharge rate of 8.1 inches per year.

Two development scenarios were examined to assess changes in water-budget fluxes. In scenario $\mathrm{A}$, when development was predominantly low-density residential with 5 to 10 percent commercial development along principal roadways, mean annual streamflow increased by 53 percent, overland flow increased by 84 percent, base flow decreased by 15 percent and annual recharge to the regional ground-water system was reduced by 10 percent. In development scenario $B$, the entire North Fork and intervening area basins contained 50 percent commercial and 50 percent medium density residential land use. Annual storm runoff increased by over 450 percent. The ground-water model for the Pheasant Branch that used the scenario $B$ recharge rates simulated a lowered water table with zero base flow and that flow from Frederick Springs would be reduced 26 percent from present-day (1993-98) conditions.An additional example application of the model evaluated locations of flood detention ponds and potential recharge areas that may mitigate the changes in flood peaks and ground-water recharge resulting from urbanization.

From February 1998 through July 1998, water-quality samples were collected by use of stage-activated automated samplers. Median suspended-sediment concentrations were similar between the North and South Fork Basins (194 and $242 \mathrm{mg} / \mathrm{L}$, respectively); however, for other constituents, North Fork values were considerably higher: median phosphorus concentrations by 4 times $(1.5$ and $0.35 \mathrm{mg} / \mathrm{L})$, median ammonia concentrations by 13 times $(1.9$ and $0.14 \mathrm{mg} / \mathrm{L})$, and the phosphorus-to-sediment ratio by more than 6 times $(21$ and $3.1 \mathrm{mg} / \mathrm{g}$ ). 


\section{INTRODUCTION}

Pheasant Branch (fig. 1) is a tributary to Lake Mendota in Dane County in south-central Wisconsin. It drains an $18.3-\mathrm{mi}^{2}$ area that includes parts of the Towns of Middleton and Springfield and the Cities of Madison and Middleton. The watershed consists of rolling upland hills, some of which are cultivated; heavily cultivated fields in the flood plains; and large areas of residential, commercial, and light industrial development.

As the City of Middleton and its surroundings continue to develop, the North Fork Pheasant Branch Basin is expected to undergo appreciable urbanization. The population of Middleton has increased from 8,246 (1970) to $11,851(1980)$ to 16,129 (2000). For the downstream City of Middleton, headwater urbanization can result in increased flood peaks, increased water volume, and increased pollutant loads. More subtly, it may also change ground-water recharge and adversely affect downgradient ecosystems such as the Pheasant Branch Marsh and Springs complex (fig. 1).

To provide a scientific basis for evaluating changes to the water resources of the upper Pheasant Branch watershed as the hydrologic system responds to changes in land use in the North Fork Basin, the U.S. Geological Survey, in cooperation with the Wisconsin Department of Natural Resources and the City of Middleton, did a study to collect additional data and refine hydrologic modeling of the area. In addition, the study was to evaluate alternative management practices to mitigate the possible effects of urbanization. Whereas many hydrologic studies only may focus on the ground-water or surface-water components of the hydrologic system, this study included all elements of the hydrologic cycle. This study built on a previous investigation (Krug and Goddard, 1986) that examined stream-channel morphology and documented a noncontinuous rainfall-runoff model used to simulate individual storm hydrographs.

\section{Purpose and Scope}

This report details a rainfall-runoff model that encompasses all elements of the hydrologic cycle including rainfall, snowmelt, evapotranspiration, interflow, streamflow, base flow, and ground-water recharge.

The entire hydrologic system was characterized quantitatively; output from surface-water modeling (recharge) was coupled with a ground-water model that was also developed in conjunction with this modeling effort (Hunt and Steuer, 2000). This coupling of surface-water and ground-water models allowed more realistic representation of urbanization effects on surface-water stormflows and ground-water recharge than would be possible using either model separately, and it provided an additional check of the flux exchanged between the ground-water and surface-water systems.

The surface-water model was focused on the North Fork Basin; however, inclusion of the South Fork Basin in the modeling effort was necessary to assess effects at the downstream City of Middleton (Highway 12 basin outlet). The model was used to quantify base flow, flood peaks, flood volumes, and ground-water-recharge differences resulting from two North Fork urbanization scenarios. The model was also used to assist in locating potential sites where stream channels and (or) surrounding land could be modified for flood-peak control and enhanced infiltration. Additionally, this report summarizes sediment and phosphorus loads from three subbasins.

\section{Description of Study Area}

The overall watershed comprises the South Fork Basin, the North Fork Basin, and a lower system that flows into the Pheasant Branch Marsh (fig. 1). At the marsh, flow from the stream combines with flows from a springs complex and ground-water discharge to the marsh. This combined flow ultimately discharges into Lake Mendota. This study is directed at the area upstream from Highway 12 (fig. 1); for the purpose of this study, this area is referred to as the "basin outlet."

The hydrology of the watershed has been appreciably modified over the last 100 years. Prior to 1900 , the Pheasant Branch watershed above Highway 12 drained into a large wetland that occupied the flat-lying land surrounding the present confluence of the North and South Forks (Maher, 1999). The watershed was likely closed in most years; but in extremely wet years, flow may have spilled into the Black Earth Creek watershed to the west. In the mid-1800s, the wetland was drained to Lake Mendota. Most of the present-day channels in the upper Pheasant Branch watershed formed or were constructed after land in the watershed was converted to agricultural uses.

The North Fork Basin has relatively steep hills in the headwaters and extensive flat areas farther 


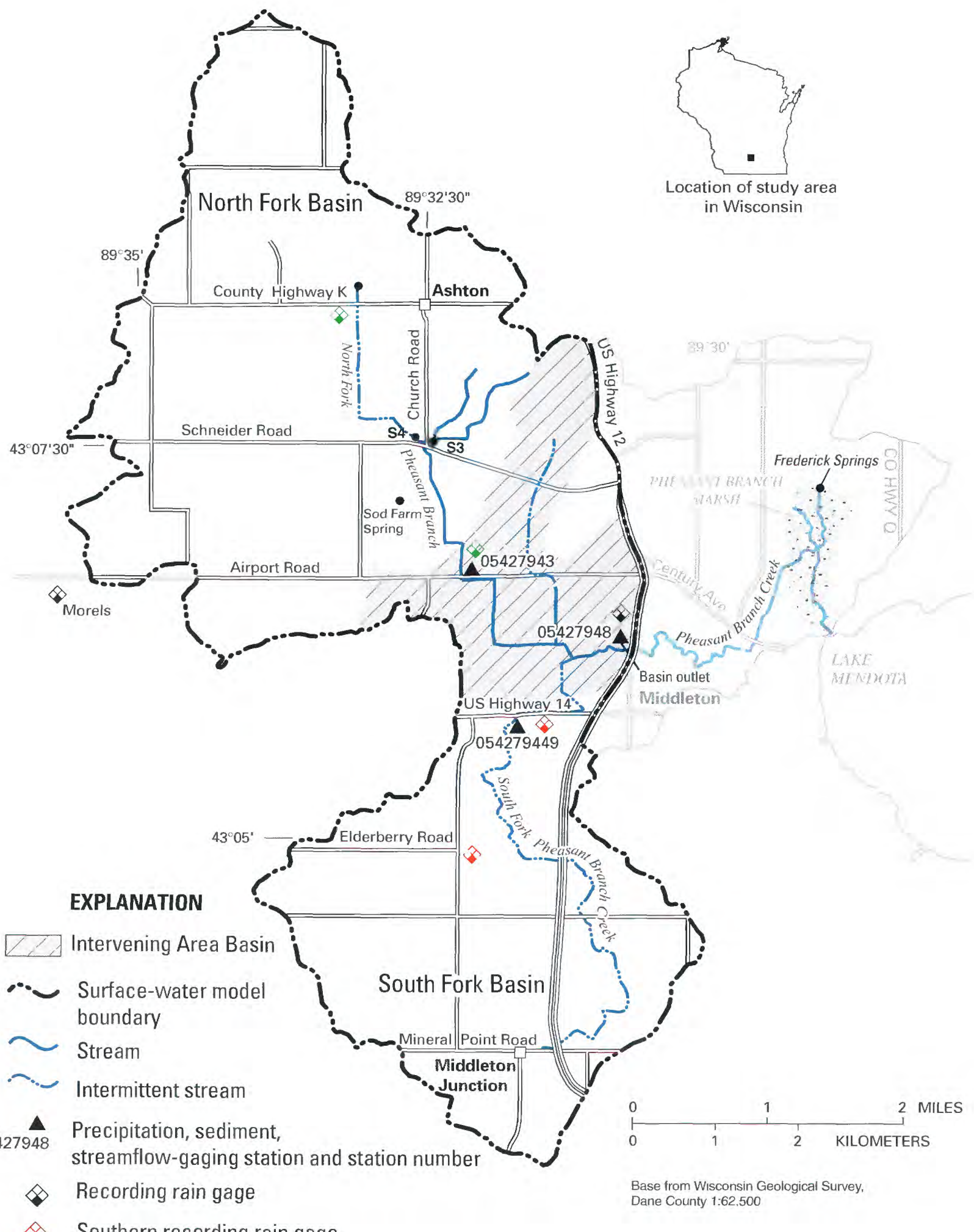

Southern recording rain gage

Northern recording rain gage

- Stage sensor

Figure 1. Location of study area, stream-gaging stations, rain gages, and storage sensors, Pheasant Branch Basin near Middleton, Dane County, Wis. 
downstream. In the flood plain, the stream channels have been straightened and dredged for agricultural drainage. This North Fork channel contains a small amount of base flow, most of which enters the channel south of Schneider Road.

The South Fork Basin probably had no welldefined channel prior to European settlement. This basin is highly urbanized, containing areas of residential, commercial, and light industrial land use. Storm runoff from impervious areas results in an ephemeral stream. Numerous detention ponds have been constructed in the South Fork Basin in an attempt to reduce peak stream stages and extent of flooded areas.

The area between the North and South Fork streamflow-gaging stations and the basin outlet at Highway 12, for the purpose of Krug and Goddard (1986) and this report, is termed the "intervening area" (IA). This intervening area has very little relief, is primarily developed as a commercial/industrial area, with no stormwater-detention ponds. Natural flood-plain storage areas both immediately north and south of Airport Road (fig. 1) can accommodate some channel overflow.

Pheasant Branch Basin soils are mostly silts and mucks. These soils are moderately deep to deep, ranging from well drained to poorly drained. The predominant soil types in the North Fork Basin are St. Charles (19.8 percent), McHenry (14.4 percent), Dodge (12.3 percent), and Batavia ( 9.7 percent) (Glocker and Patzer, 1978).

\section{Acknowledgments}

The authors thank the City of Middleton Public Works Department, The Friends of Pheasant Branch, and Dr. Kenneth Potter of the University of Wisconsin, for their assistance during the project. Assistance from George Leavesley, Kate Flynn, and Bill Krug (of the USGS) was critical to model development. Special thanks are extended to Bill Selbig, Judy Wierl, and Camilla Correl (USGS, Wisconsin District) for their assistance in data collection.

\section{BACKGROUND DATA}

\section{Base Flow}

The 50-percent-exceedance streamflow at Highway 12 is $1.8 \mathrm{ft}^{3} / \mathrm{s}$ (Holmstrom and others, 1999). Four rounds of dry-weather streamflow measurements indicated that much of the streamflow during low-flow periods originated south of Schneider Road (table 1; fig. 1). About 10 percent of the Highway 12 streamflow may originate from a spring in a sod farm west of the main North Fork channel and south of Schneider Road. From Highway 12 to Century Avenue, streamflow in the Pheasant Branch Creek increased approximately 25 percent.

\section{Continuous Streamflow Data}

Two short-term (less than two years) streamflowgaging stations were installed at the North Fork and South Fork Basin outlets to provide a continuous streamflow record and to collect water-quality data from varied land uses (table 2). The North Fork gage monitored rural runoff, whereas the South Fork gage primarily monitored urban runoff. The long-term Highway 12 gage (basin outlet) included the commercial intervening area (IA) along with the North Fork and South Fork streamflow. Daily mean streamflow data for the three stations have been published separately (Holmstrom and others, 1998).

In addition, temporary stage-recording devices were established on three small subbasins (County Highway K, northeast, and northwest of the Schneider Road and Church Road intersection) to provide continuous information on the timing and amount of streamflow (fig. 1). Ratings at these sites were poor, therefore data are considered more qualitative than quantitative.

\section{Soil-Infiltration Data}

One of the project objectives was to assist in determining where development could take place while minimizing change to recharge or runoff; therefore, it was necessary to examine the spatial variation of infiltration rates. In an attempt to differentiate infiltration rates in the North Fork Basin, 37 double-ring infiltrometer tests (Bouwer, 1986) were done over a combination of soil types and land use. In general, infiltration increased 


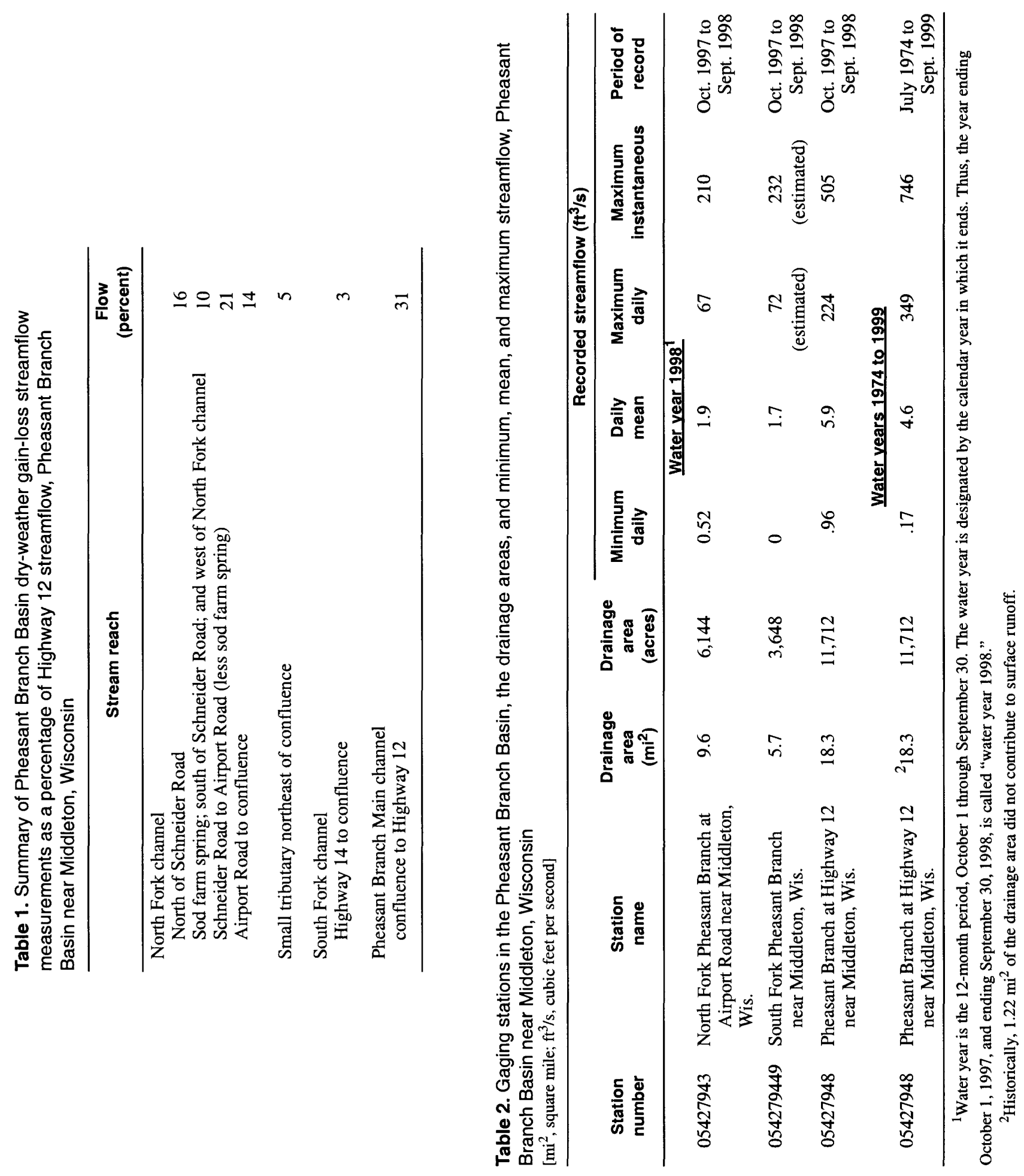


Table 3. Selected properties for five soil types in the Pheasant Branch Basin near Middleton, Wisconsin [From Glocker and Patzer, 1978; in., inch; ft, foot; in/hr, inch per hour; in/in, inch per inch; >, greater than]

\begin{tabular}{|c|c|c|c|c|c|}
\hline Soil type & $\begin{array}{l}\text { Depth from } \\
\text { surface } \\
\text { (in.) }\end{array}$ & $\begin{array}{l}\text { Depth to } \\
\text { bedrock } \\
\text { (ft) }\end{array}$ & $\begin{array}{l}\text { Seasonal high } \\
\text { water table } \\
\text { (feet below land } \\
\text { surface) }\end{array}$ & $\begin{array}{l}\text { Permeability } \\
\quad \text { (in/hr) }\end{array}$ & $\begin{array}{c}\text { Available } \\
\text { water capacity } \\
\text { (in/in soil) }\end{array}$ \\
\hline \multirow[t]{4}{*}{$\overline{\text { Batavia }}$} & $0-10$ & $>10$ & $3-5$ & $0.63-2$ & $0.2-.24$ \\
\hline & $10-44$ & & & $.63-2$ & $.18-.22$ \\
\hline & $44-50$ & & & $.63-2$ & $.16-.2$ \\
\hline & $50-60$ & & & $>20$ & $.02-.04$ \\
\hline \multirow[t]{4}{*}{ Dodge } & $0-9$ & $5-10$ & $>5$ & $.63-2$ & $.18-.22$ \\
\hline & $9-29$ & & & $.63-2$ & $.16-.2$ \\
\hline & $29-40$ & & & $.63-2$ & $.14-.18$ \\
\hline & $40-60$ & & & $2-6.3$ & $.08-.12$ \\
\hline \multirow[t]{3}{*}{ Granby } & $0-10$ & $>10$ & $0-1$ & $2-6.3$ & $.06-.1$ \\
\hline & $10-29$ & & & $6.3-20$ & $.03-.05$ \\
\hline & $29-60$ & & & $6.3-20$ & $.03-.05$ \\
\hline \multirow[t]{3}{*}{ Kegonsa } & $0-12$ & $>10$ & $>5$ & .63-2 & $.2-.24$ \\
\hline & $12-33$ & & & $.63-2$ & $.18-.22$ \\
\hline & $33-60$ & & & $>20$ & $.02-.04$ \\
\hline \multirow[t]{4}{*}{ St. Charles } & $0-15$ & $>10$ & $3-5$ & $.63-2$ & $.18-.22$ \\
\hline & $15-41$ & & & $.63-2$ & $.16-.2$ \\
\hline & $41-50$ & & & $.63-2$ & $.16-.2$ \\
\hline & $50-60$ & & & $2-6.3$ & $.08-.12$ \\
\hline \multirow[t]{2}{*}{ Wacousta } & $0-12$ & $>10$ & $0-1$ & $.2-.63$ & $.2-.24$ \\
\hline & $12-60$ & & & $.2-.63$ & $.14-.18$ \\
\hline
\end{tabular}

from agriculture to woodland to Conservation Reserve Program (CRP) land.

Five test sites in the Batavia soil/CRP land-use combination had high infiltration rates consistent with published infiltration (greater than $20 \mathrm{in} / \mathrm{hr}$ in subsurface layers; table 3 ). The absence of heavy machinery use on CRP land, and the presence of a long established root structure allowed water to reach the deeper sandy soil profile, resulting in the high rates (fig. 2a). The Batavia soil that was used in agriculture had an appreciably smaller infiltration rate (fig. 2b). On occasion, Kegonsa soil on CRP land in soil also had very high infiltration rates (fig. 2c).

There were also observable infiltration-rate differences among soil types within a consistent land use (agriculture). Double-ring infiltrometer tests produced saturated conductivity $\left(\mathrm{K}_{\mathrm{sat}}\right)$ in Granby soils of 17 to $20 \mathrm{in} / \mathrm{hr}$. This result contrasts markedly with Wacousta soil in an agricultural setting, for which infiltration was not more than $0.2 \mathrm{in} / \mathrm{hr}$. These infiltration data were used to formulate the Green-Ampt parameters used in the rainfall-runoff model. The field-test infiltration rates were in agreement with published data (table 3).

\section{Precipitation Data}

Long-term precipitation data collected with a nonshielded tipping bucket gage at the Highway 12 site provided most of the record to drive the 6-year model simulation (1993-98). Five short-term precipitation sites (North Fork and South Fork, 1997-98; Elderberry, Morel, and Highway K, February-August 1998) were installed for the study. These sites provided east-west and north-south coverage (fig. 1) and were useful in examining runoff from small subbasins along with the 

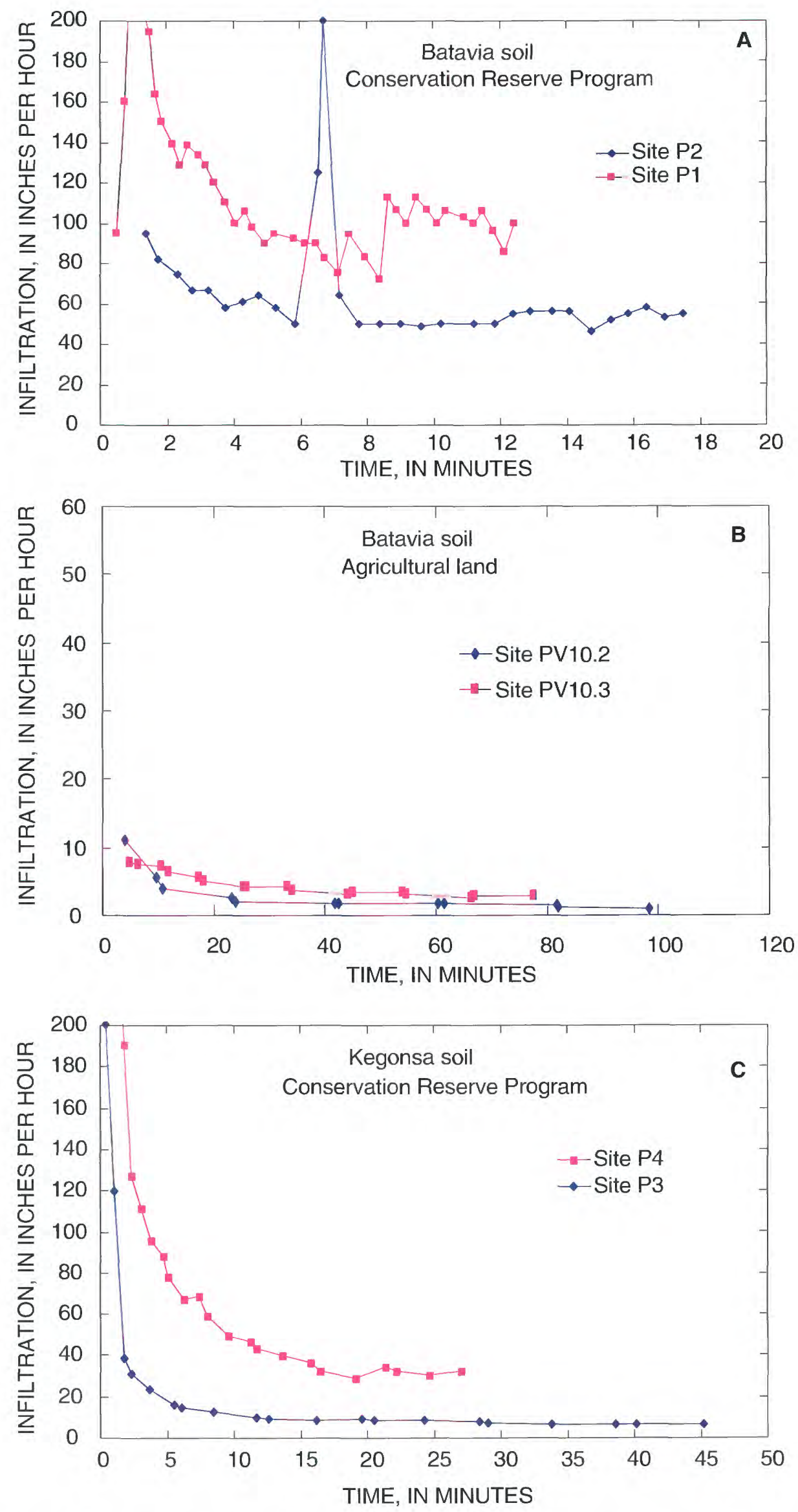

Figure 2. Double-ring infiltration results at six sites for a combination of land use and soil types, Pheasant Branch Basin near Middleton, Dane County, Wis. 
effects of localized storm cells. Precipitation at Highway 12 was comparable to the other sites (fig. 3). For two events (March 29 and August 4, 1998), measurements at the Highway 12 precipitation gage were appreciably different from those at the other sites in the basin, and the Highway 12 precipitation gage was likely in error. Thus, for two events, precipitation data combined from several sites was used as model input.

\section{Water-Quality Data}

From February 1998 through July 1998, waterquality samples (for total phosphorus, total suspended sediment, and ammonia) were collected at the North Fork, South Fork, and Highway 12 sites (fig. 1) by means of stage-activated automated samplers. Automated sampling, which makes use of equipment programmed to collect samples at a single point in response to changes in stage of a stream, has been shown to be an effective method of describing rapid changes in water quality (Graczyk and others, 1993). Point-sample concentrations were periodically compared to concentrations from samples that were collected at equal width increments over the entire stream depth and width; results from eight such samples verified the representativeness of the point samples.

Concentration and load data have been published in Holmstrom and others (1998). Median suspended-sediment concentrations were similar between the North and South Fork Basins (194 and $242 \mathrm{mg} / \mathrm{L}$, respectively); however, for other constituents, North Fork values were considerably higher: median phosphorus concentrations by 4 times ( 1.5 and $0.35 \mathrm{mg} / \mathrm{L})$, median ammonia concentrations by 13 times ( 1.9 and $0.14 \mathrm{mg} / \mathrm{L}$ ), and the phosphorus-to-sediment ratio by more than 6 times (21 and $3.1 \mathrm{mg} / \mathrm{g}$ ).

Suspended-sediment samples were collected at the Highway 12 site during 1989-99. For 1998, the Highway 12 site sediment and phosphorus loads, which are the sum of the South Fork, North Fork, and intervening area basin loads, were in the midrange of the longerterm record (fig. 4). Most of the Highway 12 sediment and phosphorus loading in 1998 resulted during three storms (fig. 5). The intervening area generated the greatest water volume and sediment load (table 4).

On a unit-area basis (load divided by basin area), the commercial/industrial intervening area basin was the largest generator of water volume, sediment, and phosphorus loads (fig. 6). Although the amount of the intervening area basin's connected impervious area is similar to that of the South Fork, the intervening area generated substantially more runoff. This increased runoff may be a result of less permeable soils in the intervening area, or the absence of detention or storage areas in the intervening area as contrasted with designed storage available in the South Fork Basin.

\section{WATERSHED MODEL}

The Precipitation Runoff Modeling System (PRMS; Leavesley and others, 1983) was selected for use in the study because it is a deterministic, distributed-parameter modeling system developed to evaluate the effects of various combinations of precipitation, climate, and land use on flow regimes, flood peaks and volumes, soil-water relations, and ground-water recharge (fig. 7). Additionally, PRMS continuously simulates the water fluxes of each component of the hydrologic cycle and calculates snowmelt and evapotranspiration processes on the basis of maximum and minimum daily temperature. PRMS also permits changing of the computational and output time step during a simulation. This change feature allowed for an efficient continuous simulation (daily time step) for extended intervals to calculate the recharge and base-flow fluxes. During substantial rain events, the simulation could then be set to 5-min computational and output time steps to simulate flood hydrographs necessary in the urbanization assessment.

Although the project objectives focused primarily on the North Fork Basin, the long-term observed streamflow record was at the Highway 12 site; therefore, the South Fork and intervening area basins were included in model simulation.

With PRMS, the overall basin was conceptualized as an interconnected series of reservoirs whose collective output produces the total hydrologic response. These reservoirs include interception storage in the vegetation canopy, impervious-area storage on the surface, storage in the soil zone, subsurface storage between the basin surface and the water table, and ground-water storage (Leavesley and others, 1983). The movement of water from one reservoir to another is computed throughout the simulation. Daily maximum and minimum air temperature, along with daily and 5-min precipitation time-series data were used for model input.

Basin heterogeneity was accounted for by dividing the basin into Hydrologic Response Units (HRUs) 

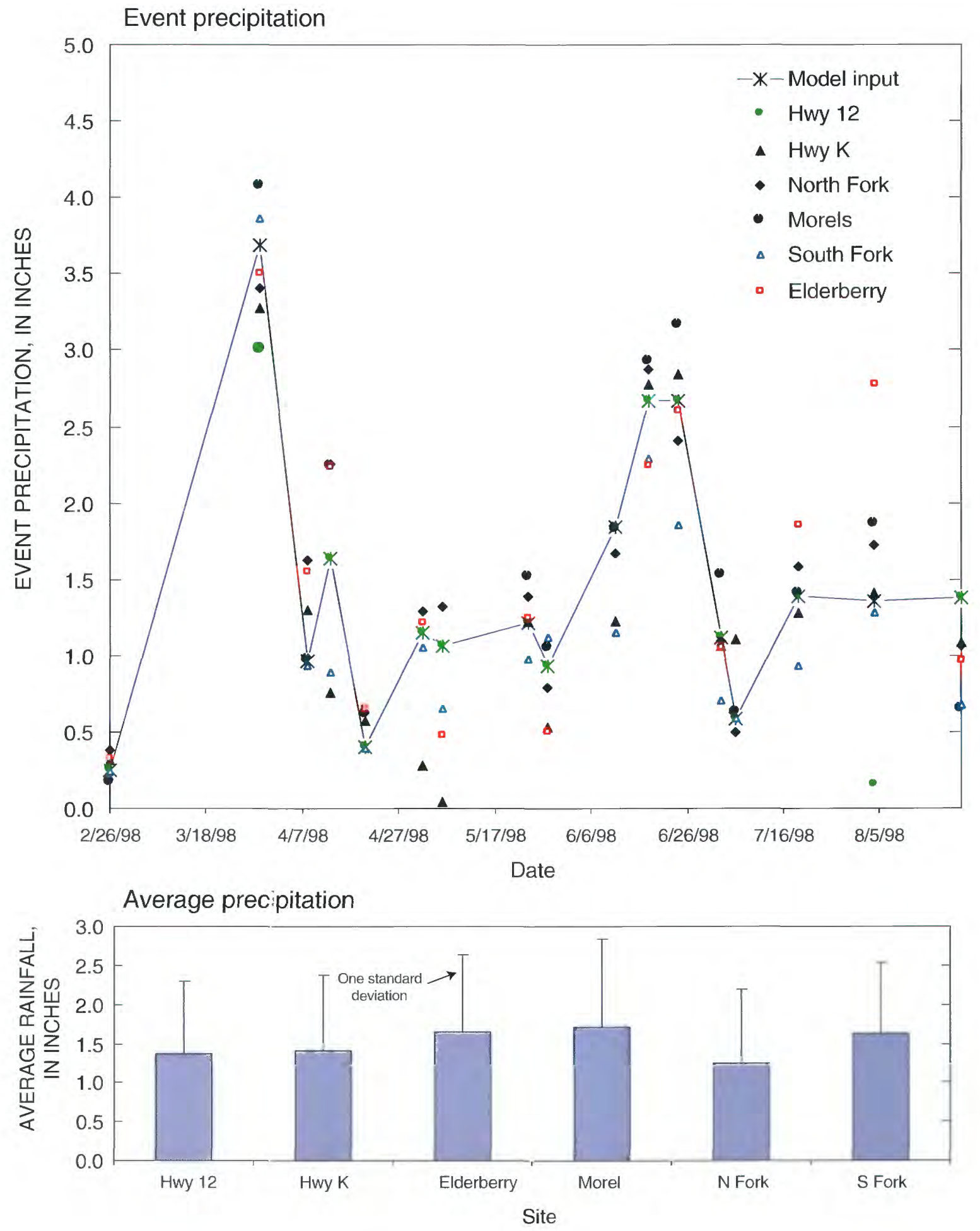

Figure 3. Event precipitation and average precipitation at the six rain-gage sites in Pheasant Branch Basin near Middleton, Dane County, Wis., from February 1998-August 1998. 
Table 4. Water volumes, phosphorus loads, and suspended-sediment loads during February 1-August 31, 1998, in Pheasant Branch Basin near Middleton, Wisconsin

$\left[\mathrm{ft}^{3} / \mathrm{s}\right.$, cubic foot per second]

\begin{tabular}{lccc}
\hline \multicolumn{1}{c}{ Basin } & $\begin{array}{c}\text { Water volume } \\
\text { (cfs-days) }\end{array}$ & $\begin{array}{c}\text { Phosphorus } \\
\text { (pounds) }\end{array}$ & $\begin{array}{c}\text { Suspended } \\
\text { sediment } \\
\text { (tons) }\end{array}$ \\
\hline North Fork & 570 & 3,290 & 300 \\
South Fork & 570 & 1,450 & 560 \\
Intervening Area & 710 & 2,610 & 1,820 \\
Highway 12 & 1,850 & 7,350 & 2,680 \\
\hline
\end{tabular}

Total suspended sediment
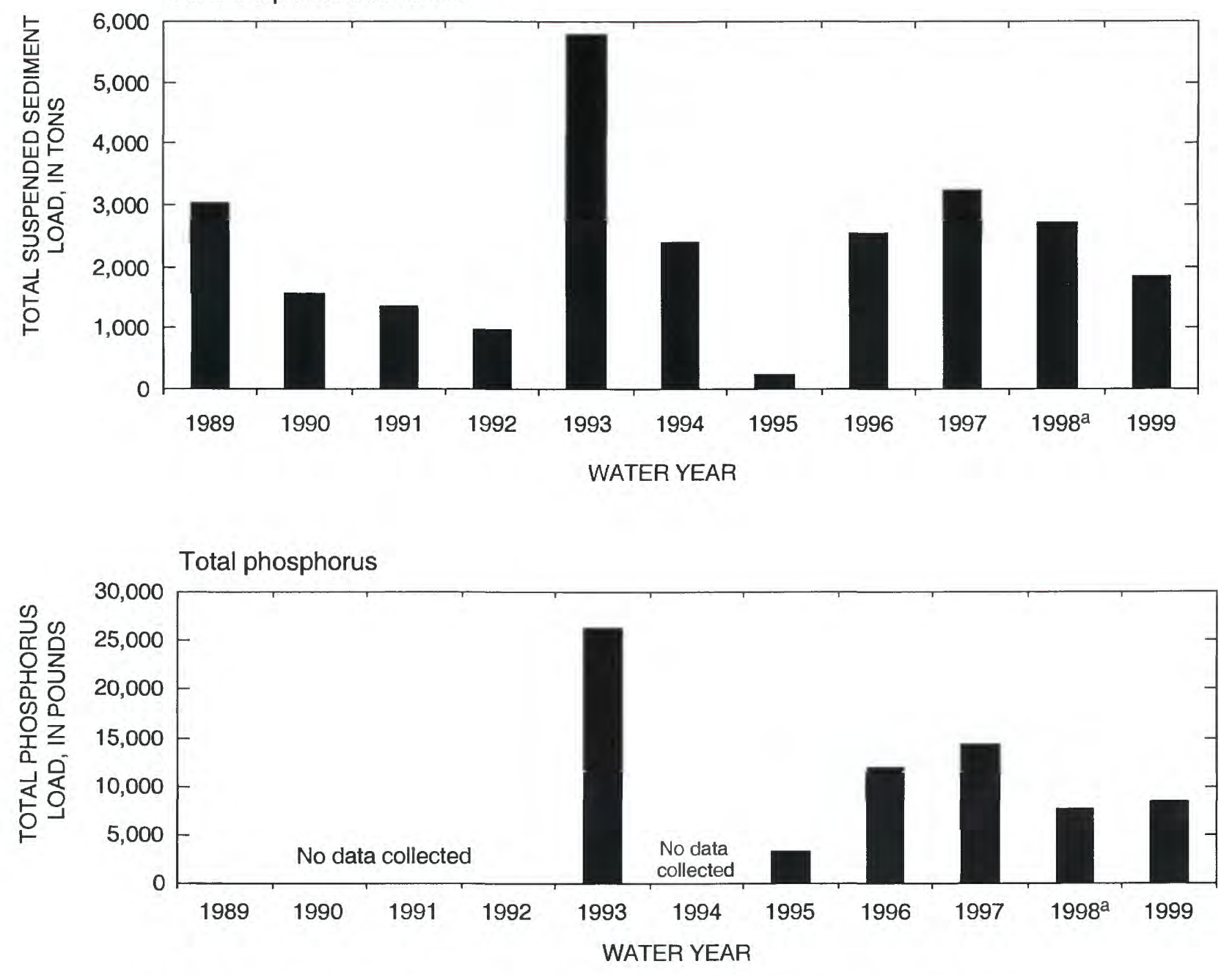

a Water quality was monitored at North and South Fork Subbasins in addition to Highway 12.

Figure 4. Annual loads of total suspended sediment and total phosphorus for Pheasant Branch Creek at Highway 12, near Middleton, Dane County, Wis., water years 1989-99. 

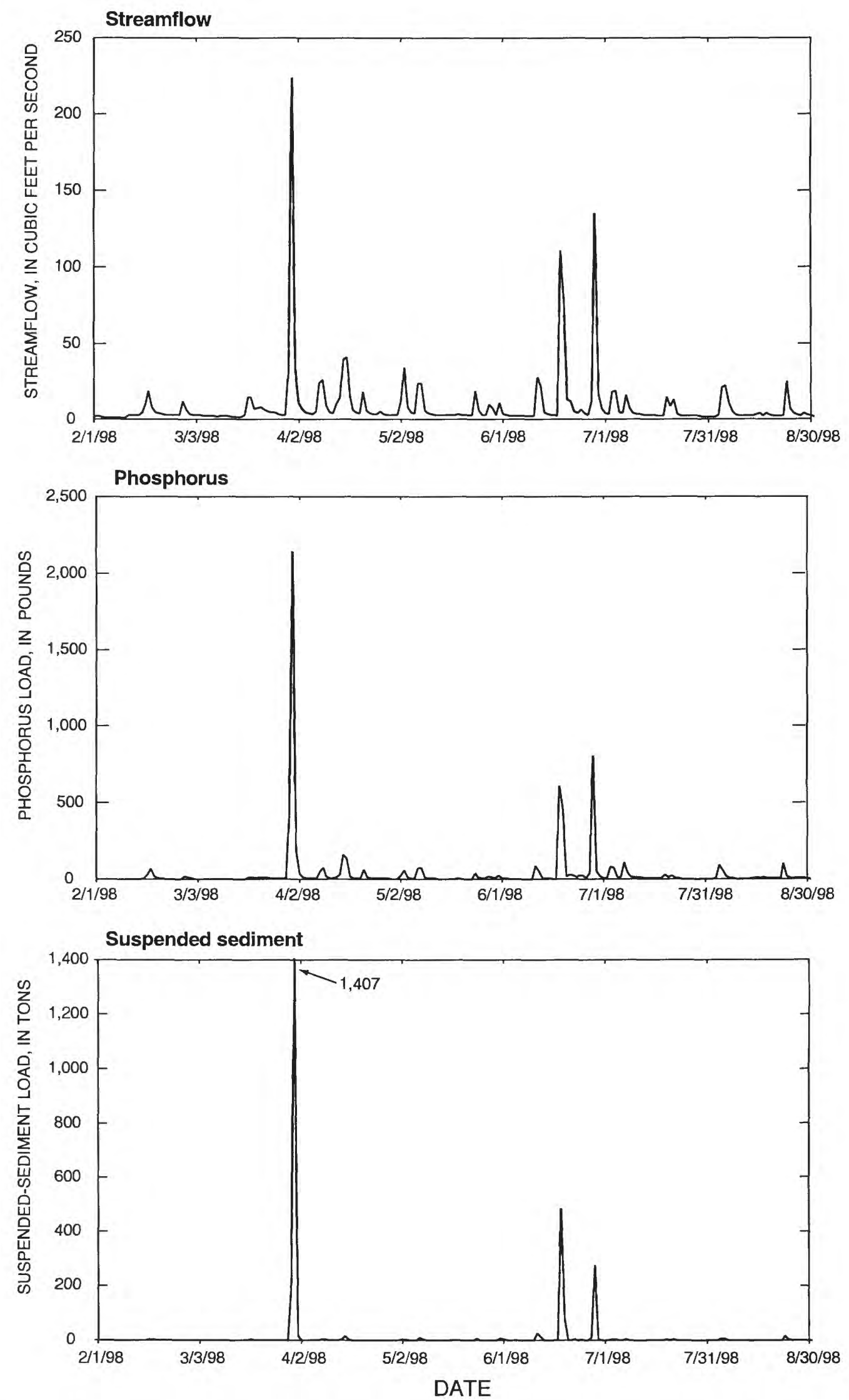

Figure 5. Pheasant Branch Creek streamflow at Highway 12, near Middleton, Dane County, Wis., and associated loads of phosphorus and suspended sediment, February 1998 through August 1998. 

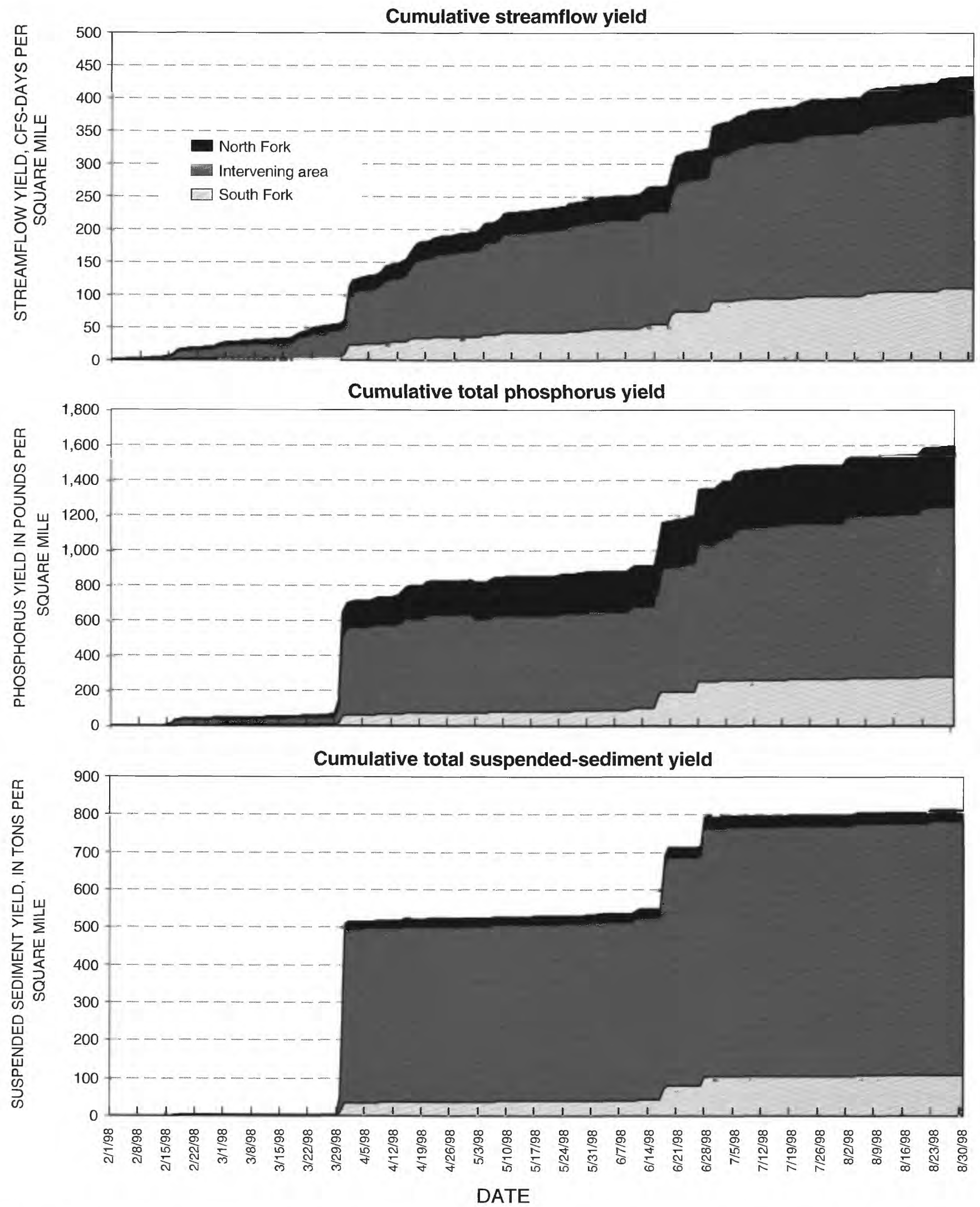

Figure 6. Cumulative streamflow, phosphorus loads, and suspended-sediment yields (loads per unit contributing area) for Pheasant Branch Creek subbasins, near Middleton, Dane County, Wis., February 1998 through August 1998. 


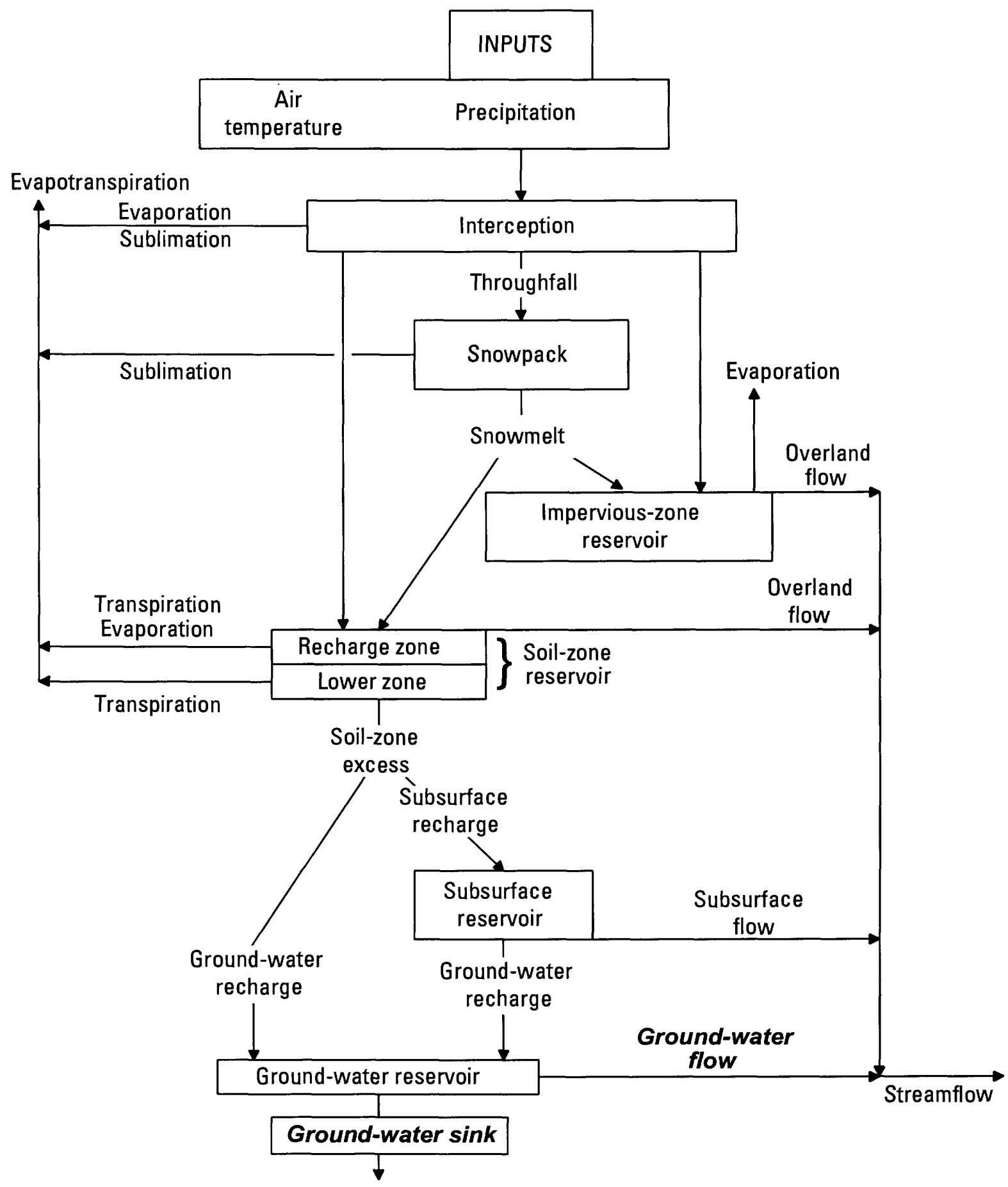

Figure 7. Schematic diagram of the Precipitation-Runoff Modeling System (PRMS). (Modified from Leavesley and others, 1983, fig. 2.) 
according to characteristics such as slope, aspect, elevation, vegetation type, soil type, land use, and precipitation distribution. Water and energy balances were computed daily for each HRU. The sum of the HRU responses, weighted on a unit-area basis, produced the daily system response and basin streamflow. Because factors such as surface runoff, interception storage, infiltration, and soil rooting depth varied among HRUs, distributed parameters were used to assign specific values to each HRU.

In this specific model application, the HRU delineation was also based on monitoring-site locations, effective imperviousness, infiltration characteristics, base flow and ground-water flow (fig. 8; table 5). Regional ground-water-model results (Krohelski and others, 2000) indicated that the entire South Fork Basin recharge and a part of the North Fork Basin recharge did not contribute to Pheasant Branch Creek base flow. This finding was partially confirmed with six sets of discharge measurements made during low flow (table 1). Many of the HRU parameters used in the model are summarized in table 5.

In this study, potential evapotranspiration losses were computed as a function of daily mean air temperature and maximum possible hours of sunshine (Hamon, 1961). The model routine used to simulate the initiation, accumulation, and depletion of a snowpack in each HRU (daily computation) was based on the conceptual model of Obled and Rosse (1977). Daily shortwave radiation and sky cover was estimated from maximum and minimum daily air temperatures (Thompson, 1976; Tangborn, 1978).

In the storm-hydrograph simulation, a second level of PRMS application was used wherein the watershed was conceptualized as a series of interconnected flow planes and channel segments. Surface runoff was routed over the flow planes into the channel segments; channel flow was then routed through the watershed channel system (fig. 9). Each flow plane was assigned to an HRU to establish infiltration parameters (table 5). Channel- and overland-flow-plane routing was based on a finite-difference approximation of the continuity equation and the kinematic-wave approximation, relating flow and the cross-sectional area of flow.

The reservoir, flow-plane, and channel network used in the event mode was based on topographic maps and mapped imperviousness (actual area that is impervious). Mapped impervious area for the South Fork Basin was obtained from a City of Madison Source Loading and Management Model (SLAMM), and that for the intervening area basin was obtained from the City of Middleton. Relations converting the mapped imperviousness to connected (or effective) imperviousness came from Sutherland (1995). Connected or effective impervious area is that which is directly connected to the drainage-collection system; runoff is not dispersed to an infiltration area.

Channel dimensions and Manning roughness coefficients were approximated on the basis of field reconnaissance and information published in Krug and Goddard (1986). Channel roughness remained constant throughout the growing season; Manning roughness coefficients ranged from 0.04 to 0.06 . The natural flood-plain areas north of Airport Road and at the confluence of the North Fork and South Fork were simulated with physically descriptive reservoirs at each site (fig. 9). The numerous South Fork storage areas, however, were represented by expanding the detention pond at the South Fork outlet and lengthening the input channel to account for travel-time delay.

Daily and event (5-min) precipitation data from the Highway 12 site were used to drive the model during the nonwinter period. From November through March, the precipitation from the Truax Airport snow gage $(6 \mathrm{mi}$ from the Highway 12 site) was used. Daily maximum and minimum temperatures measured at the Truax Airport were used in the model evapotranspiration and snowmelt calculations.

\section{Model Calibration, Evaluation, and Results}

The model was run for 1 year of record prior to the calibration period to establish initial conditions such as storage in the ground water, subsurface, and soil-zone reservoirs (fig. 7).

Risley (1994) provides a detailed explanation of a PRMS calibration for 11 small drainage basins on the Oregon Coast Range; only a brief summary of the calibration procedure is included in this report. The first part of the calibration was a trial-and-error adjustment of those parameters relating to the annual water balance of the basin. Coefficients that were applied to the Hamon evapotranspiration formula (Hamon, 1961) were selected such that the simulated annual potential evapotranspiration, 37 to $40 \mathrm{in} / \mathrm{yr}$, agreed with published values for southern Wisconsin (Farnsworth and Thompson, 1982). PRMS required that the starting and ending months for plant transpiration be specified in the model. April (starting) and November (ending) were 


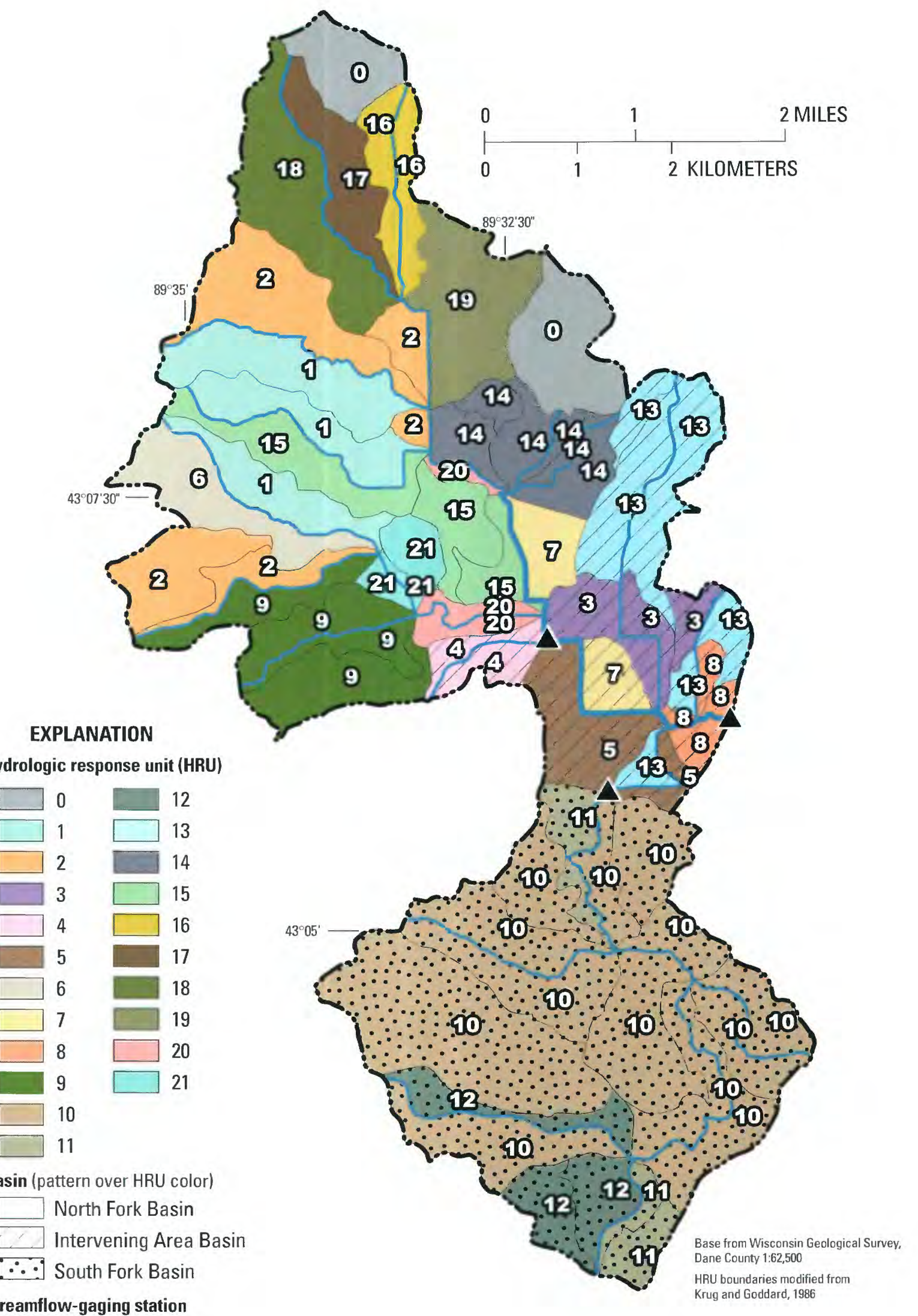

Figure 8. Hydrologic response units (HRUs) used in daily mode simulations, Pheasant Branch Basin near Middleton, Dane County, Wis. 


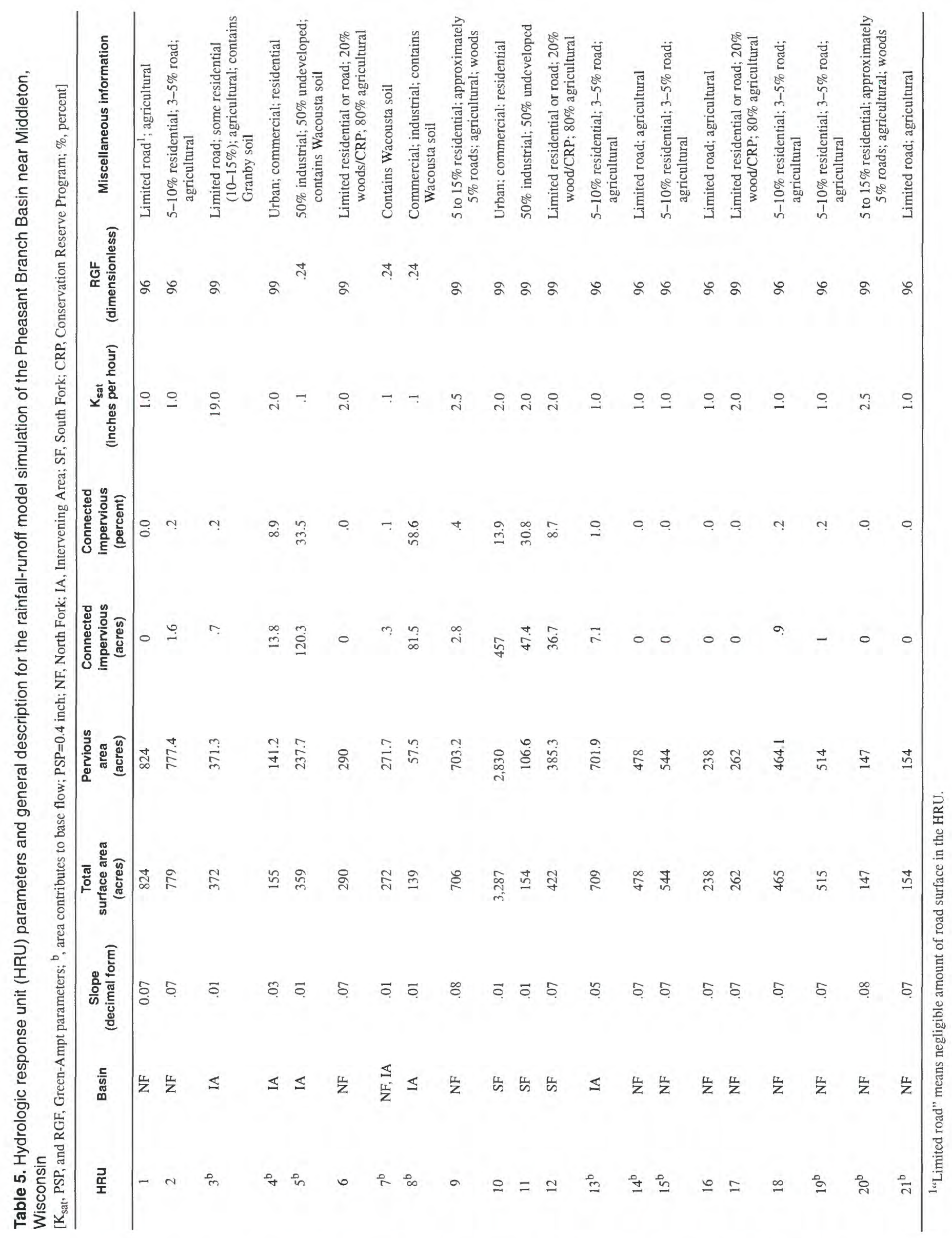




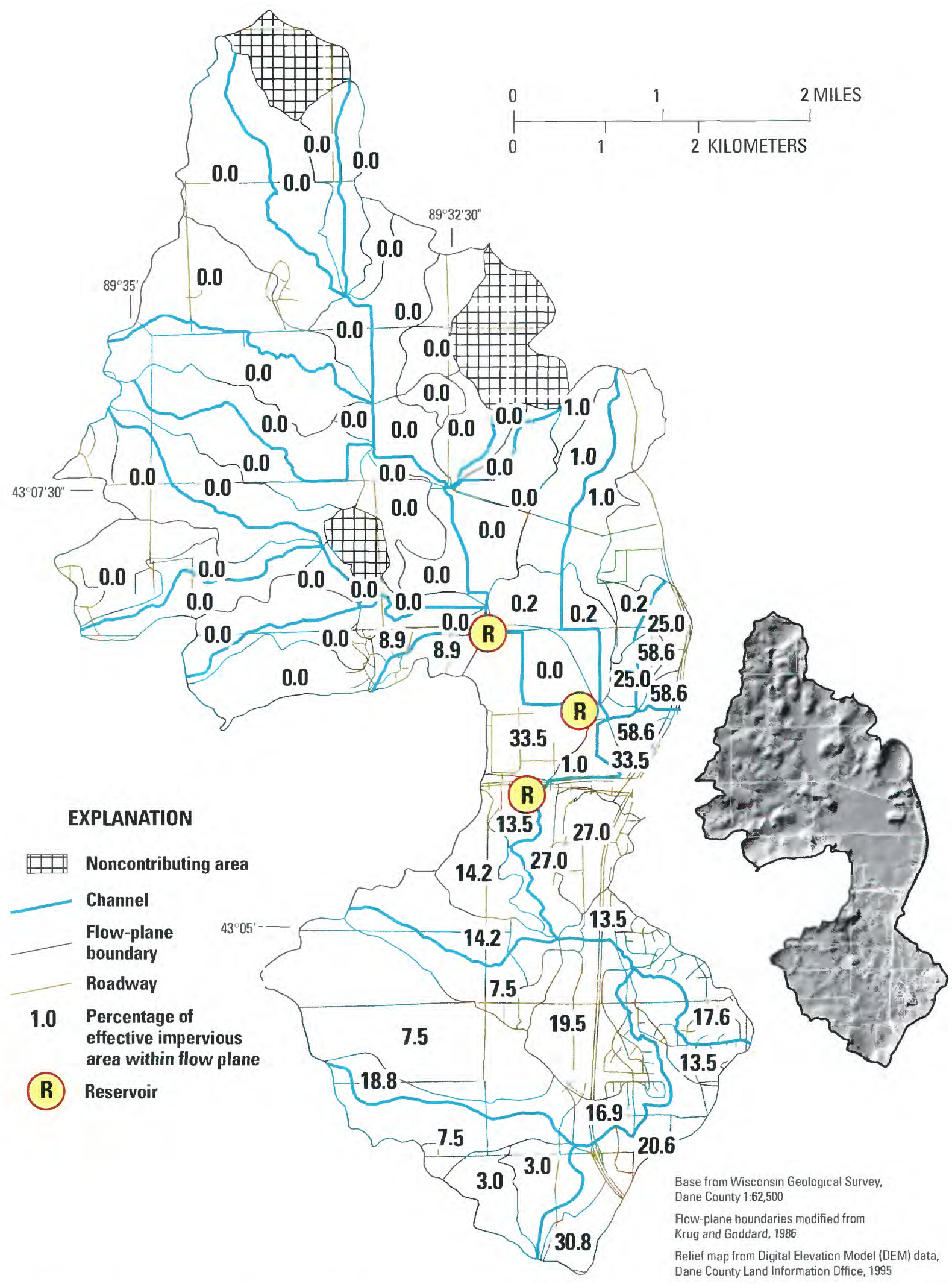

Figure 9. Channel network, flow planes, impervious area, and reservoirs used in the storm-hydrograph simulations, Pheasant Branch Basin near Middleton, Dane County, Wis. 
selected on the basis of stage data as recorded in a nearby wetland that responded dramatically to evapotranspiration and subsequent plant senescence (Randy J. Hunt, U.S. Geological Survey, unpub. data, 1998).

The rainfall precipitation record was not adjusted during model calibration. The snowfall precipitation was increased by 5 percent basinwide, however, to calibrate snowmelt water masses. This increase is in line with the typical estimated snow gage under measurement (Kenneth Potter, University of Wisconsin, and George Leavesley, U.S. Geological Survey, oral commun., 1998).

To further balance the annual water budget, the ground-water sink coefficient was adjusted to control the amount of water leaving the basin (ground-water sink; fig. 7). This value was a constant coefficient throughout the simulation over the entire basin; the actual water flux was a function of the amount of water at any given time in the ground-water reservoir. The HRU ground-water-reservoir model design (three independent ground-water-reservoirs) was such that all the South Fork ground water and some of the North Fork ground water (table 5) departed the basin by way of the ground-water sink term (RCB was set equal to zero). Therefore, channels in these areas had no base-flow component; they were ephemeral. Daily mode parameters were evaluated after determination that the model, on an annual basis, adequately represented both the wet years (1993; 50.3 in. of precipitation) and dry years (1994; 30.3 in. of precipitation) (fig. 10).

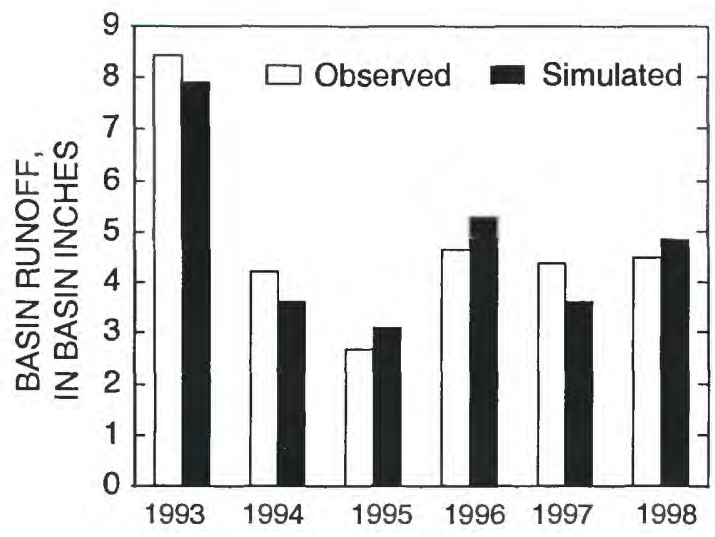

Figure 10. Observed and simulated annual runoff for Pheasant Branch Creek at Highway 12 near Middleton, Dane County, Wis., 1993-98.

For the daily mode, infiltration parameters were varied spatially according to the saturated conductivity
$\left(\mathrm{K}_{\mathrm{sat}}\right)$ values determined from the infiltration tests. For event storm mode, parameters were then adjusted to adequately simulate the shape of the storm hydrographs and base-flow recession curves; these parameters also remained constant throughout the simulation. The model adequately simulated base flows and storm events (fig. 11a and 11b). Included in the simulation was the largest instantaneous peak flow observed in the 25-year record: $746 \mathrm{ft}^{3} / \mathrm{s}$ on July 6,1993 . On an annual basis, overland flow was consistently greater than base flow (fig. 12).

Generally, the model failed to accurately simulate the timing of the snowmelt events (January through March). One possible reason was that very little calibration effort was spent with the albedo and energy exchange of the snowpack. A second reason for the poor timing simulation may be that the PRMS was limited to calculating snowmelt on a daily time step. The model did, however, acceptably compute annual runoff, of which a substantial fraction results from snowmelt (figs. 10 and 12). Simulated snowmelt in the system was often greater than annual streamflow (fig. 12). Much of this snowmelt resulted in recharge to the ground-water system.

Much of the precipitation that fell on the basin did not reach the ground-water system or the stream channel by overland flow but rather departed the basin by interception and evapotranspiration from plants and by soil- surface evaporation (fig. 12). The model adequately simulated streamflow volume on a monthly scale for the basin overall and the North Fork Basin separately (fig. 13).

Upon completion of the daily mode calibration, the model was run in event mode (5-min time step, GreenAmpt parameters) for 40 storms. An increased number of small precipitation events were defined in 1997 and 1998 so that the streamflow data collected at the South Fork and North Fork streamflow-gaging stations could be used in addition to stage data and observations at the subbasin ephemeral tributaries. These data enabled comparison between observed and simulated results for a range of precipitation events at numerous locations. Observed and simulated storm-runoff volumes and peak flows are show in figures 14 and 15 for the basin outlet and the North Fork Basin.

Storm-mode infiltration was computed by use of a variation of the Green and Ampt (1911) equation that was based on antecedent soil moisture conditions as computed in the daily mode water balance. Required storm-mode parameters included $\mathrm{K}_{\text {sat }}$ (saturated 

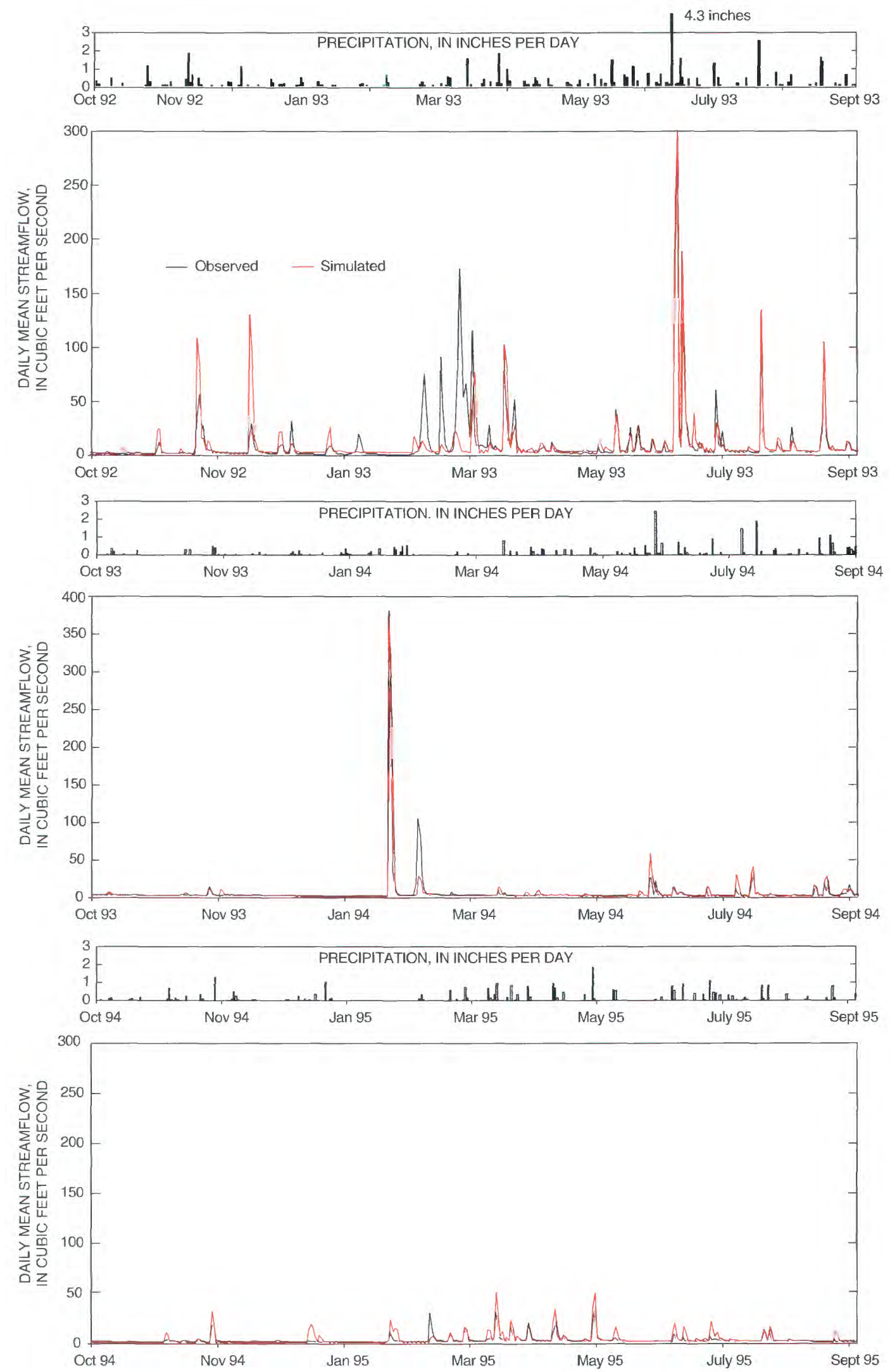

Figure 11a. Observed precipitation and observed and simulated daily mean streamflow for Pheasant Branch Creek at Highway 12, near Middleton, Dane County, Wis., water years 1993-95. 

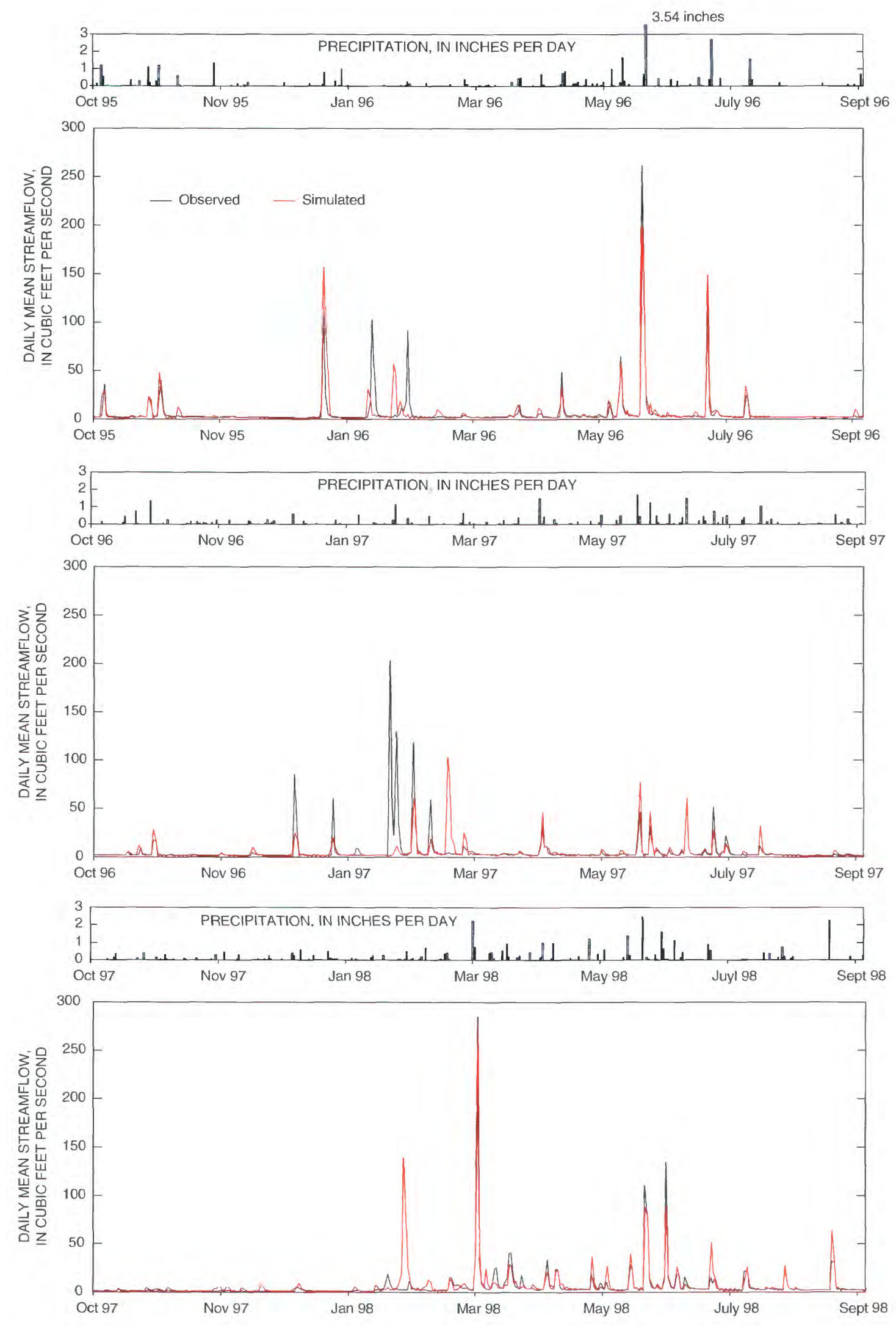

Figure 11b. Observed precipitation and observed and simulated daily streamflow for Pheasant Branch Creek at Highway 12, near Middleton, Dane County, Wis., water years 1996-98. 
SIMULATED FLUX COMPONENTS OF TOTAL ANNUAL PRECIPITATION

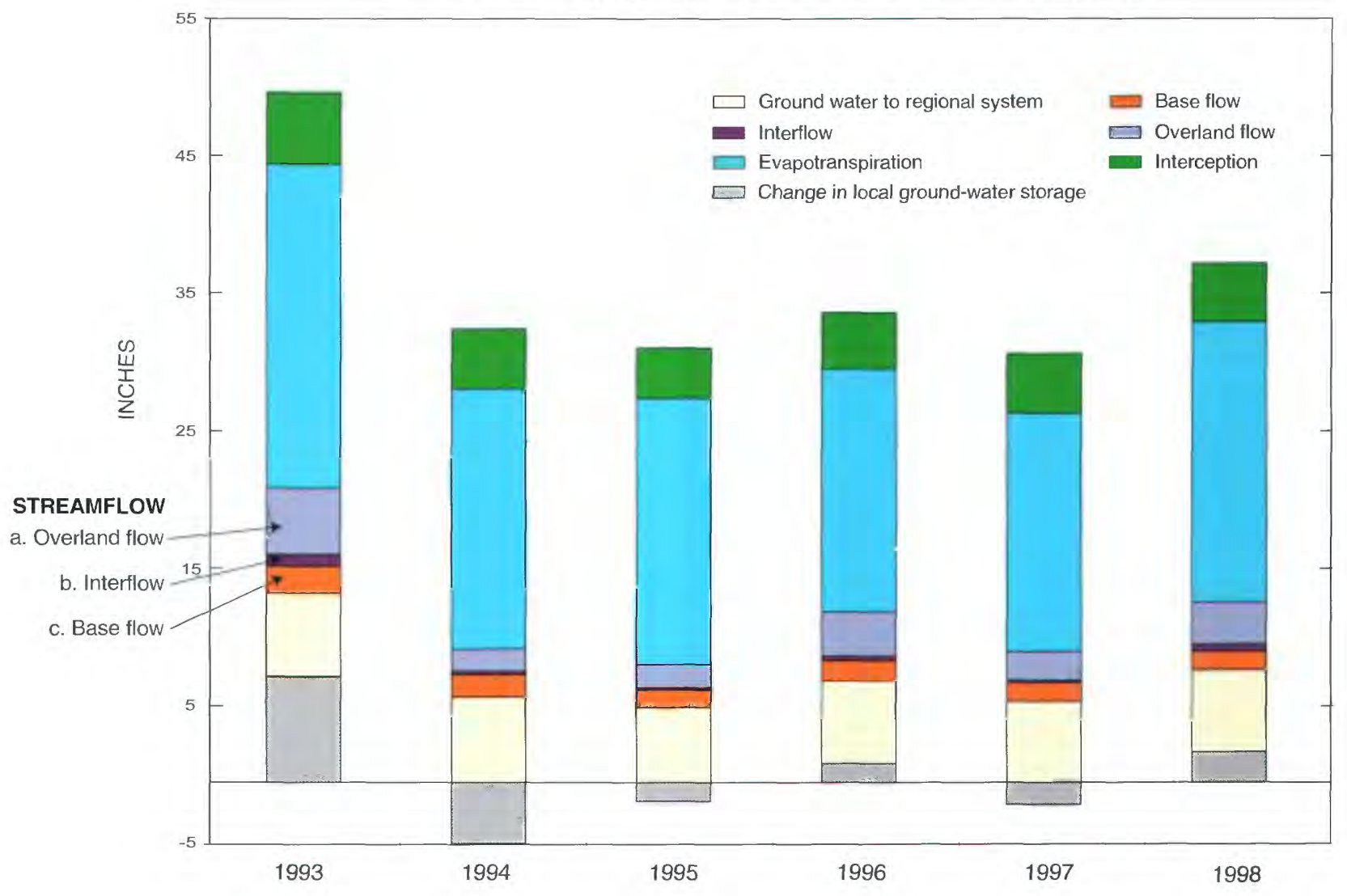

COMPARISON OF SIMULATED STREAMFLOW AND SNOWMELT AMOUNTS

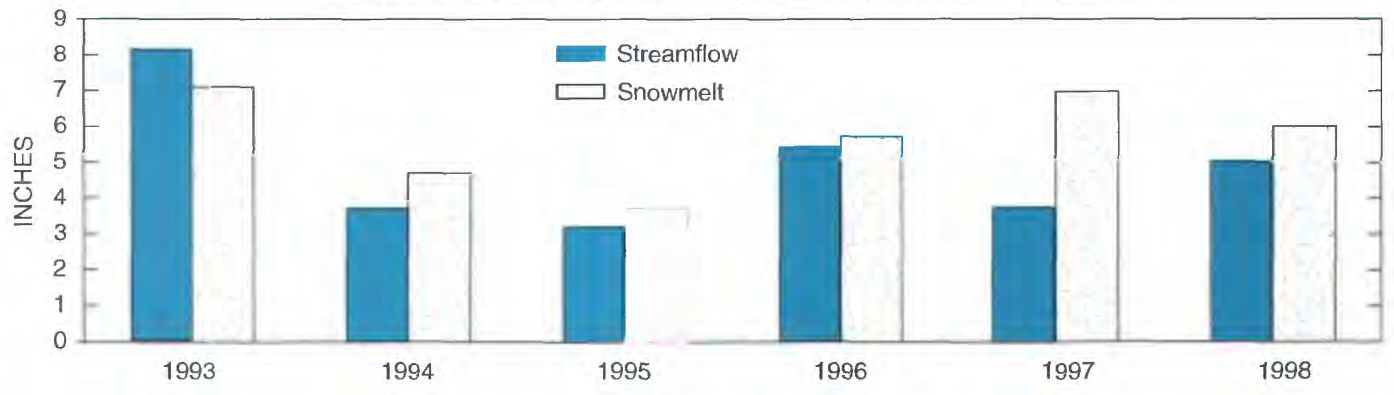

Figure 12. Simulated annual water fluxes for Pheasant Branch Creek at Highway 12, Middleton, Dane County, Wis., $1993-98$. 

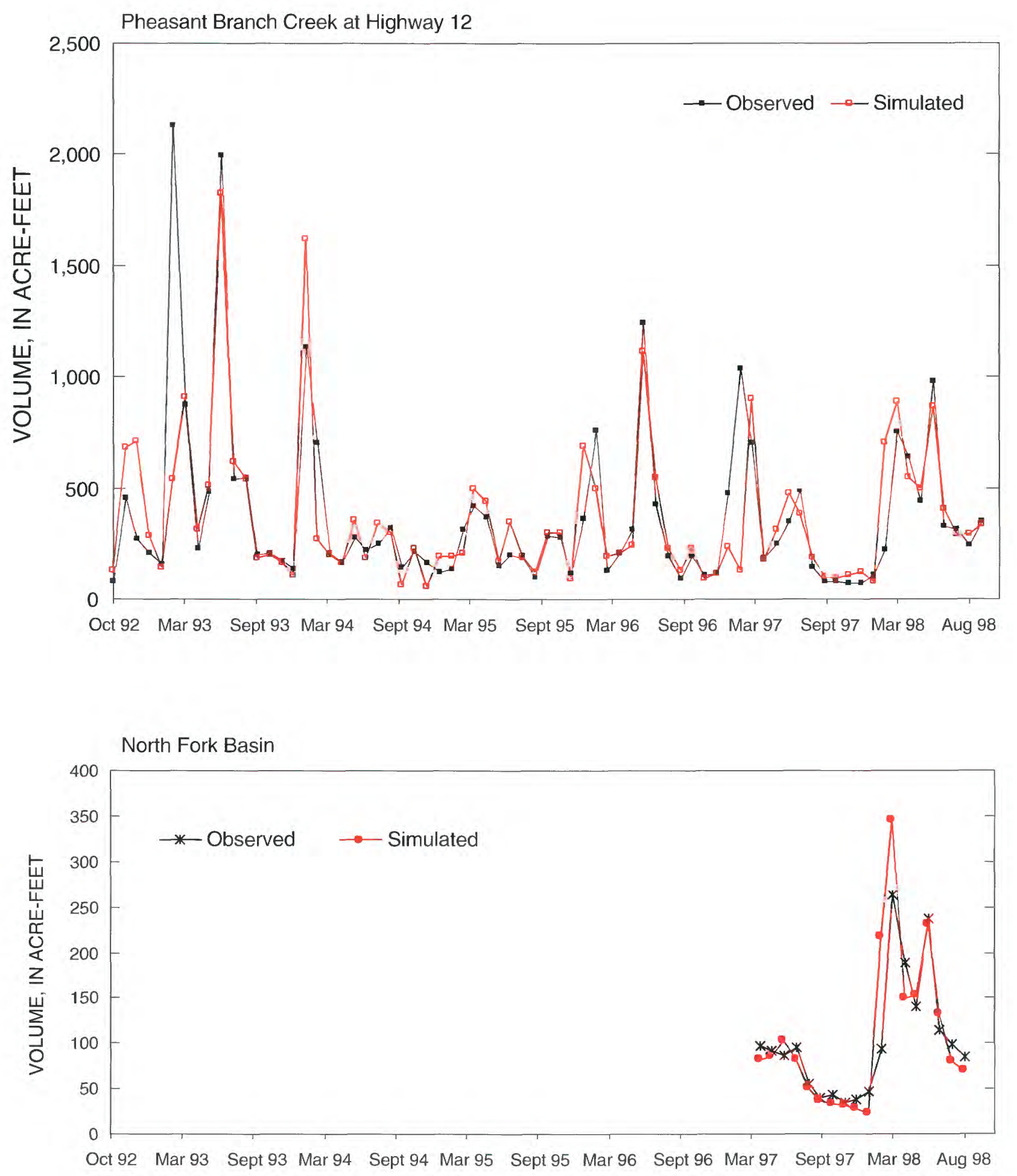

Figure 13. Observed and simulated monthly streamflow volumes for Pheasant Branch Creek at Highway 12 and the North Fork Basin, Middleton, Dane County, Wis. 

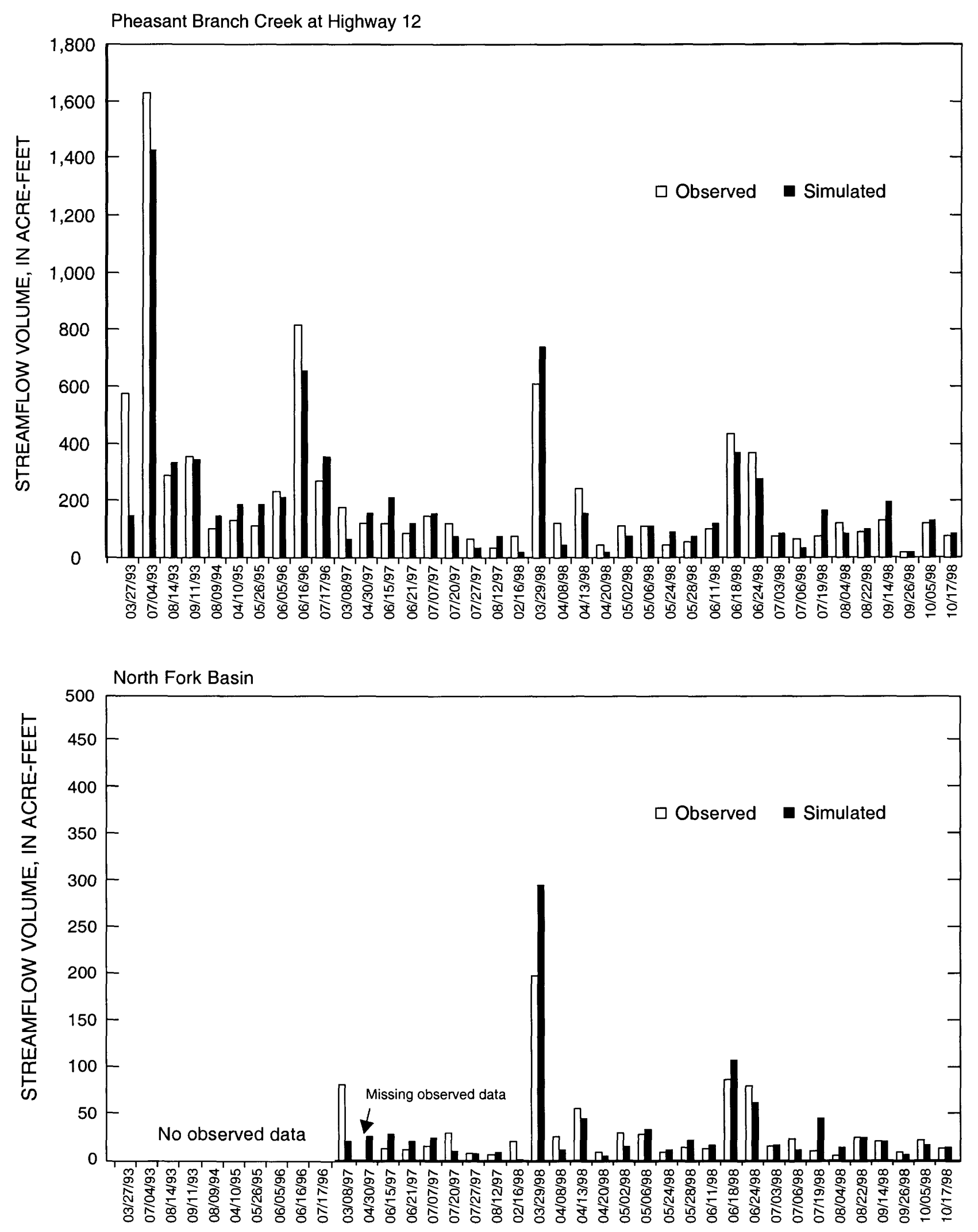

Figure 14. Observed and simulated storm-event streamflow volumes for Pheasant Branch Creek at Highway 12 and the North Fork Basin, Middleton, Dane County, Wis. 

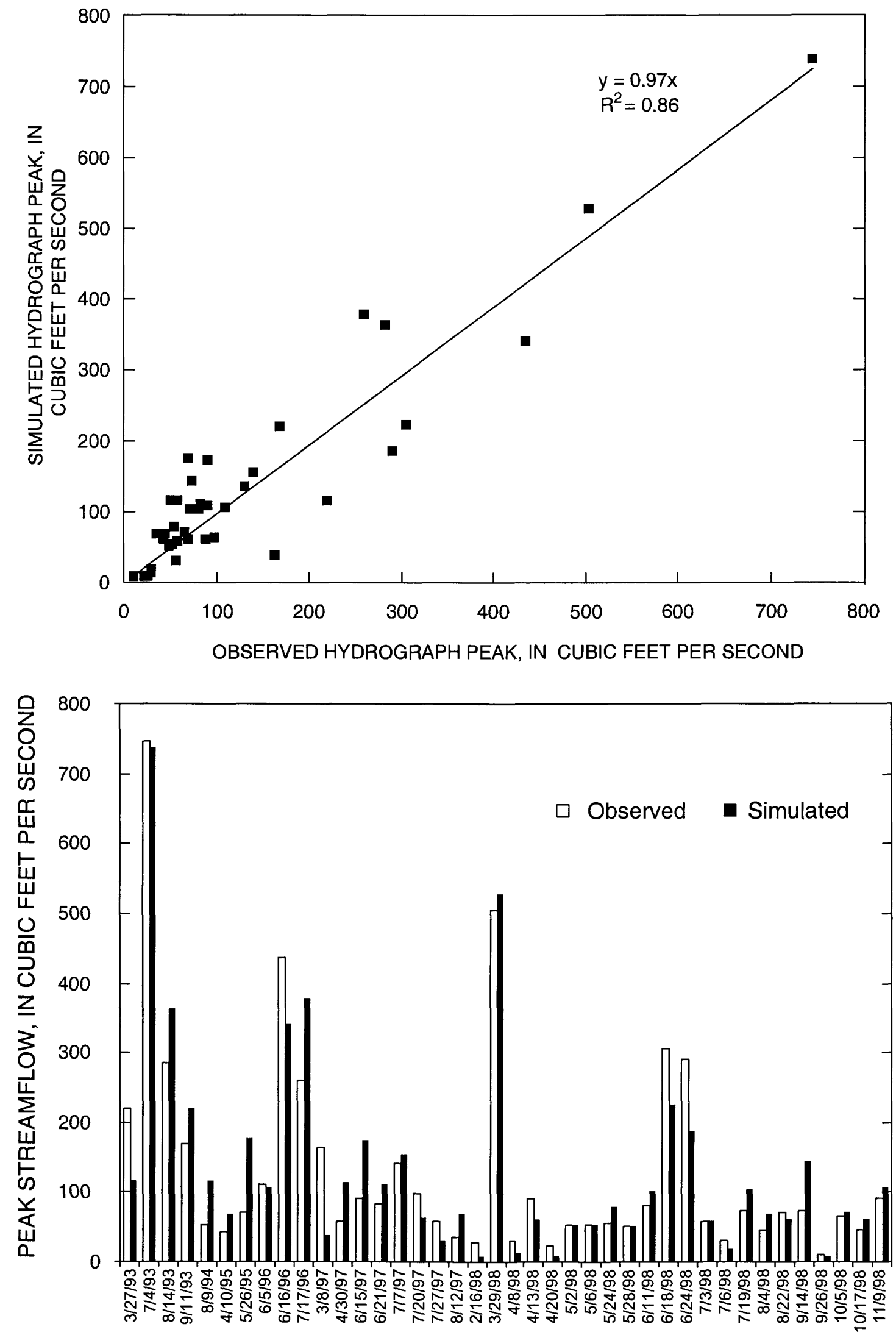

Figure 15. Observed and simulated storm peaks for Pheasant Branch Creek at Highway 12, Middleton, Dane County, Wis. 
hydraulic conductivity of the transmission zone), PSP (product of capillary drive and moisture deficit), and RGF (ratio PSP at field capacity to PSP at wilting point). The previously described infiltration tests established infiltration curves (fig. 2) at point locations in the North Fork Basin. Initial estimates for the $\mathrm{K}_{\mathrm{sat}}$, PSP, and RGF parameters were determined by curve fitting to the infiltration field test data. In the storm-mode model calibration, $\mathrm{K}_{\text {sat }}$ and PSP were kept constant but RGF was varied to affect infiltration. During calibration, RGF was raised by a constant factor throughout the varied soil/land-use combinations-this had the effect of increasing the initial infiltration and lowering the later infiltration $\left(\mathrm{K}_{\mathrm{sat}}\right)$. The $\mathrm{K}_{\mathrm{sat}}$, as determined by the double-ring infiltrometer, may have been too large because of the constant head of the field test procedure. This possible source of measurement error may be the physical reason that raising RGF (which decreased later infiltration) improved the calibration.

Storm-peak timing was calibrated by reducing the Manning's roughness coefficients in some of the North Fork channels. The fact that these coefficients must be set constant through time may be somewhat of a model limitation. Evidence was available that streamflow hydrograph peak timing changed with channel vegetation growth throughout the year.

The storage-outflow relations representing the two flood-plain areas to the north and south of Airport Road (fig. 9) were initially determined from topographic and flood-plain maps. Calibration of these relations was based primarily on the large event in July 1993. The simulated event volumes for the North Fork (fig. 14) compared favorably with the observed data, but the comparison was not as favorable for the overall basin outlet (fig. 14). Streamflow hydrograph peaks were well simulated throughout the 6-year simulation for the overall basin (fig. 15).

One of the project objectives was to develop a model to assist in assessing areas important to infiltration and recharge. Therefore, data were collected to qualitatively assess the model representation of small subbasins. Periodic reconnaissance, often including a depth measurement, was made after precipitation to determine the occurrence of flow in ditches and channels from small subbasins. More than 175 observations were made at 16 sites on the small tributaries (most were ephemeral) after precipitation events. For example, at the location where the ephemeral tributary crosses Capitol View Road (2.0- $\mathrm{mi}^{2}$ subbasin), seven observations were made that could be compared to model simulation output (fig. 16). At three observations, flow was not observed at the site nor did the model compute any flow for that channel. At four of the observations, flow was observed at the site and a depth was measured; correspondingly, the model also generated flow from the subbasin west of Capitol View Road.

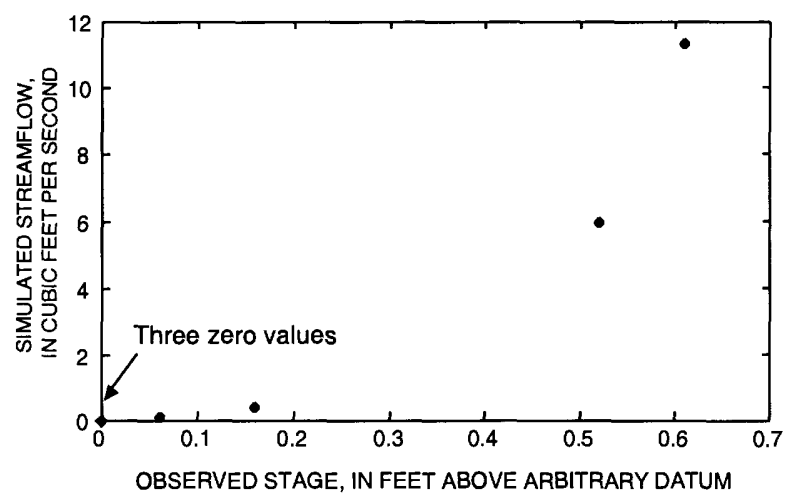

Figure 16. Observed stage and simulated streamflow for the ephemeral Capitol View Road tributary, Pheasant Branch Basin, Middleton, Dane County, Wis.

As a further effort to verify the model on a small subbasin scale, continuous stage sensors (15-min intervals) were used to measure depth at the outlets of three small subbasins within the North Fork Basin (fig. 1). For all three subbasins, too few discharge measurements were obtained to develop accurate stage-discharge relations. However, qualitative comparisons of observed and simulated storm-runoff volumes at the sites representing each subbasin (fig. 17) show that the simulated volumes generally are comparable to the observed.

For some events, the precipitation was not distributed evenly across the basin (fig. 3), yet the model was solely driven by rainfall as measured at Highway 12 . When evaluating model performance on a small-subbasin scale, it is useful to examine event streamflow in conjunction with locally measured precipitation. For example, on July 6, 1998, the Highway 12 precipitation ( 0.59 in.), which drove the model calculation, was substantially less than the local precipitation measured at Highway K (1.11 in.; fig. 3). Appropriately, the simulated streamflow volume at Highway $\mathrm{K}$ was less than the observed streamflow volume. The difference between the simulated and observed volumes would have been less had the local Highway $\mathrm{K}$ precipitation been applied to the HRUs near the Highway K precipitation gage. At sites S3 and S4, which are located 

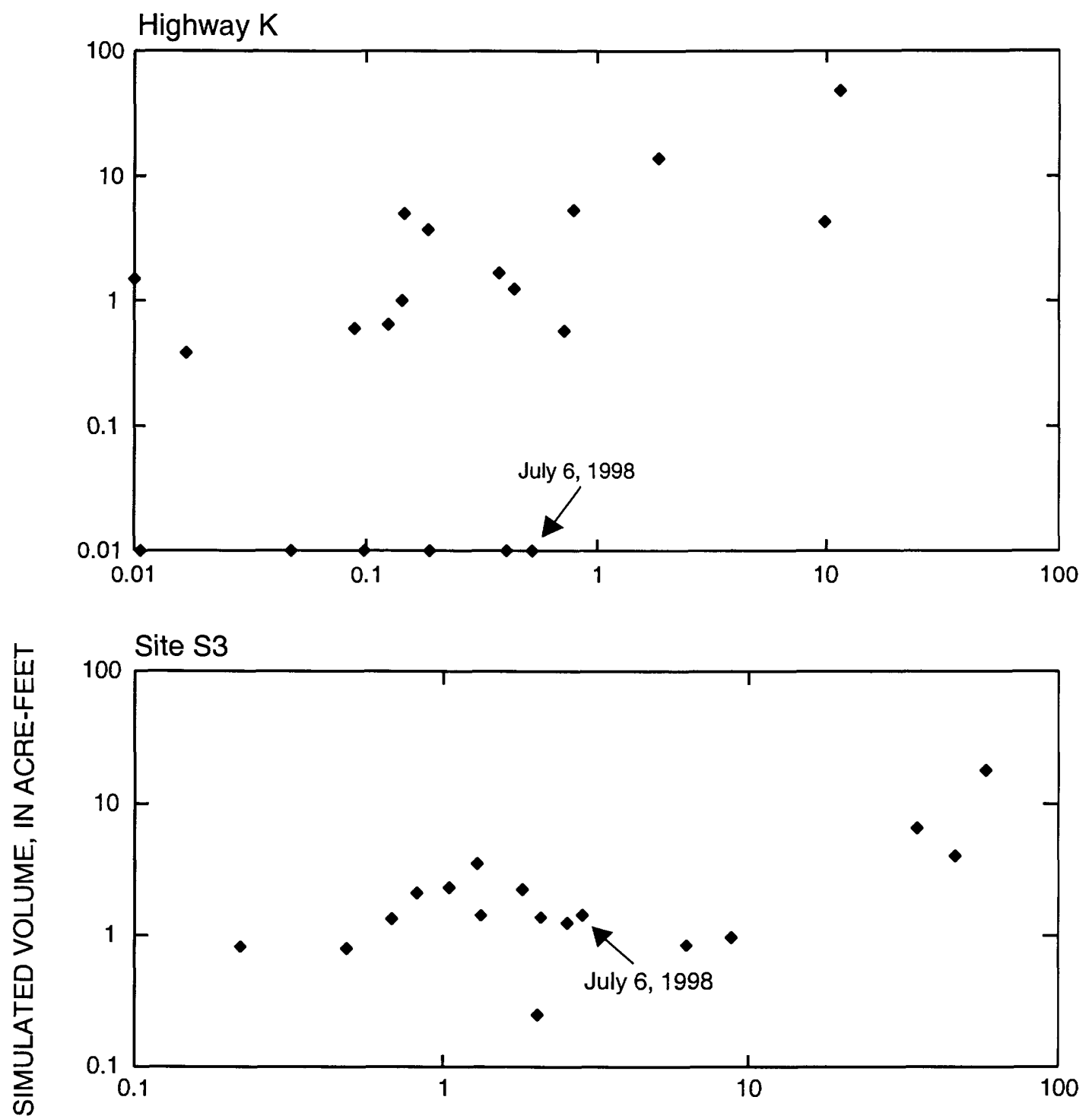

Site $\mathrm{S} 4$

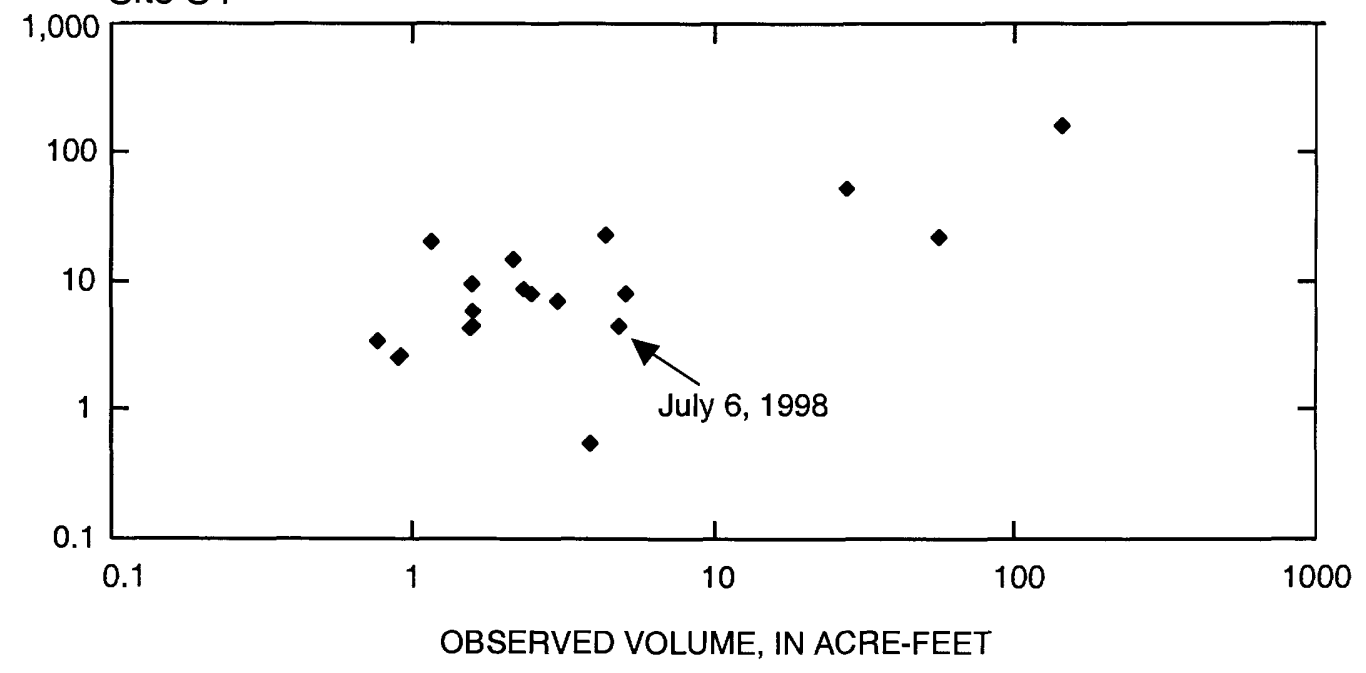

Figure 17. Observed and simulated streamflow volumes for three small North Fork tributaries north of Schneider Road, Pheasant Branch Basin near Middleton, Dane County, Wis. 
Table 6. Observed and simulated annual runoff data for model simulation, Pheasant Branch Basin near Middleton, Wisconsin

[Obs, observed runoff in inches; Sim, simulated runoff in inches; Diff, difference in inches = Sim-Obs; difference in percent (Percent diff $)=100 x([$ Sim-Obs $] / O b s)]$

\begin{tabular}{|c|c|c|c|c|c|c|}
\hline Water year & & Precipitation & Obs & Sim & Diff & Percent diff \\
\hline 1993 & & 50.3 & 8.5 & 8.0 & -0.5 & -6 \\
\hline 1994 & & 28.7 & 4.3 & 3.7 & -.6 & -14 \\
\hline 1995 & & 30.3 & 2.7 & 3.1 & .4 & 16 \\
\hline 1996 & & 34.3 & 4.7 & 5.3 & .6 & 13 \\
\hline 1997 & & 29.7 & 4.4 & 3.7 & -.8 & -17 \\
\hline \multirow[t]{2}{*}{1998} & & 37.8 & 4.6 & 4.9 & .4 & 8 \\
\hline & Total & 211.1 & 29.2 & 28.7 & -.5 & -2 \\
\hline
\end{tabular}

further south, the simulated runoff volume is similar to the observed runoff (fig. 17). If multiple rain-gage sites been operating throughout the 1993-98 simulation period, precipitation could have been spatially applied to the model improving simulation results.

Lastly, on April 15, 1998, a series of streamflow measurements and observations were made on the small tributaries of the North Fork Basin in conjunction with a runoff event (fig. 18). This was not the event for which the model best simulated the observed basin-outlet data; rather, this was the one event at which observations or measurements were made at many sites (17) in an attempt to gain insight into small-scale (spatial) model validity. Again, local precipitation was shown to be important to assessing local runoff. For example, the northern part of the basin (Highway K and North Fork rain gages) did not receive as much precipitation as was monitored at Highway 12 (which drove the model calculations). Correspondingly, the measured flows in the North Fork Basin are consistently less than simulated flows. The model did, however, generate runoff from the small tributaries in the northern and western part of the basin during the modest 1.1-in. precipitation event on April 15-16, 1998 (fig. 18). The observations and measurements corroborate the occurrence of runoff from the small subbasins.

Small-scale corroboration provides confidence in applying the model in small-scale applications. The observed measurements and monitored hydrographs agree with the model output throughout the upper Pheasant Branch system. This agreement illustrates that the model is appropriately representing infiltration and runoff in the North Fork Basin. It also demonstrates that uneven distribution of rainfall patterns can result in the failure of the model at small spatial scales.

\section{Calibration Statistics}

Observed and simulated annual data for the calibration period are shown in table 6 for the basin outlet (Highway 12). The annual runoff volume error for the 6 -year simulation period was -2 percent (simulated was less than observed) and ranged from -0.8 in. ( -17 percent) to 0.6 in. ( +13 percent).

Plots of observed and simulated streamflow were also checked for consistent periods of over simulation or under simulation (figs. 11a and 11b).

The quality of fit for monthly and daily values was examined by the coefficient of model-fit efficiency (Nash and Sutcliffe, 1970):

$$
E=\left[\sum_{1}^{N}(Q o i-Q o)^{2}-\sum_{1}^{N}(Q o i-Q s i)^{2} / \sum_{1}^{N}(Q o i-Q o)^{2}\right](1)
$$

where $\quad \mathrm{Qo}_{\mathrm{i}}$ is the observed runoff volume for month or day $i$,

$\mathrm{Qs}_{\mathrm{j}}$ is the simulated runoff volume for month or day $i$, and

Qo is the average observed monthly or daily runoff volume.

If the data and model residuals (observed minus simulated) are normally distributed, the coefficient of monthly model-fit efficiency should nearly equal the square of the correlation coefficient. The coefficient of model-fit efficiency provides a more rigorous evaluation of the amount of variation simulated in the model than the correlation coefficient because the correlation coefficient indicates only that the series being compared have similar patterns of being greater or less than their respective mean values. The correlation coefficient 


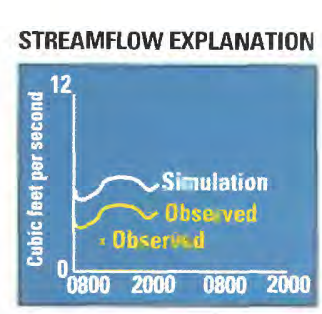

Northern rain gages (see figure 1)
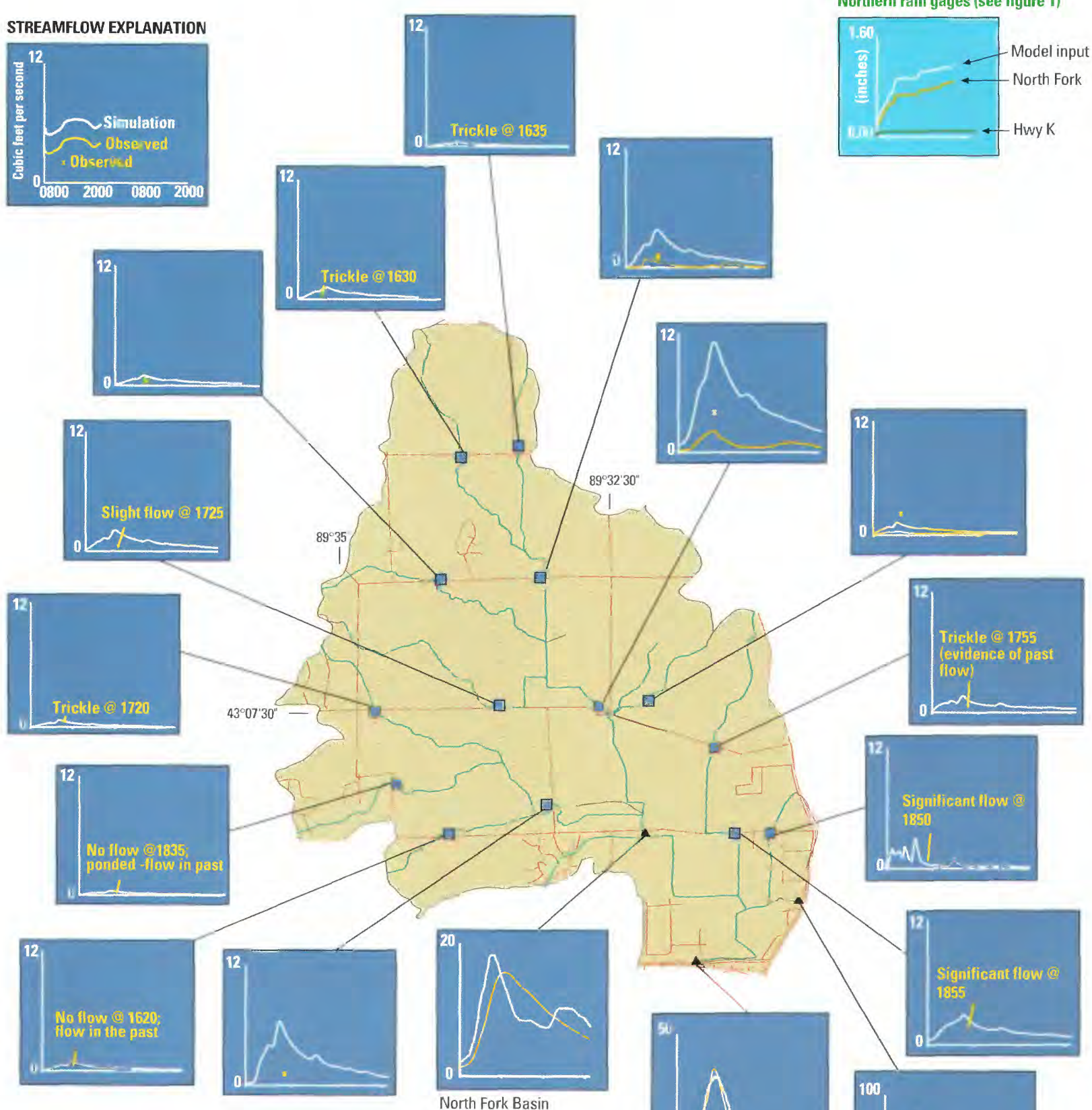

Southern rain gages (see figure 1)

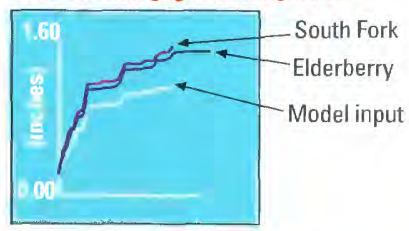

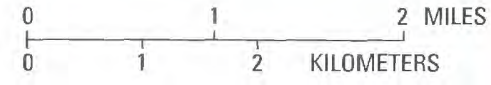

Base from Wisconsin Geological Survey, Dane County 1:62,500

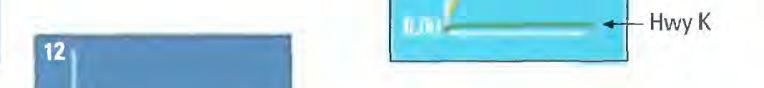


does not account for the magnitude of differences between the observed and simulated values (Dunker and Melching, 1998). The coefficient of model-fit efficiency is a direct measure of the fraction of the variance of the original data series (streamflow) simulated in the model. Computed on a monthly basis, the model-fit efficiency in this study was 0.52 for the 6 -year period. For some years, the model did not perform well in simulating the timing of snowmelt (1993, 1996, 1997, and 1998; fig. 1la and fig.11b). If the snowmelt months of December through March are removed, the model-fit efficiency increases to 0.95 . The North Fork monthly model-fit efficiency increased from 0.71 to 0.92 after the snowmelt months were removed. Computed on a daily basis, the model-fit efficiency at the basin outlet is 0.51 ; however, efficiency increased to 0.87 after the snowmelt months, December through March, were removed from the computation.

\section{Timing of Flow Peaks for the Three Subbasins}

The commercial/industrial intervening area basin is close to the Highway 12 outlet. Its location and the absence of detention storage in the intervening area basin results in its streamflow-hydrograph peak reaching the Highway 12 outlet in advance of the peaks from the other subbasins. This sequence is evident in the initial bump in the Highway 12 hydrograph (fig. 19). The initial runoff generated from the intervening area generally arrives at Highway 12 about 6 to 7 hours ahead of the ultimate Highway 12 storm peak. For the range of events (fig. 19), the South Fork and North Fork hydrograph peaks appear to occur nearly simultaneously, with a travel time to Highway 12 of 1 to 2 hours. During the large event of March 30, 1998, the South Fork monitoring equipment was overtopped, resulting in missing data.

\section{Importance of Present-Day Storage in the North Fork and Intervening-Area Basins}

The 7.26-in. precipitation event that began on July 5, 1993, illustrates the importance of present-day storage in the upper Pheasant Branch system. A total of 4.3 in. of rain fell over 7 hours, resulting in a peak flow of $746 \mathrm{ft}^{3} / \mathrm{s}$ (25-year recurrence interval) at Highway 12. The flood-plain storage ("reservoir") north of Airport Road reduced the simulated incoming peak of
$1,391 \mathrm{ft}^{3} / \mathrm{s}$ to $848 \mathrm{ft}^{3} / \mathrm{s}$ (61 percent), and the flood-plain storage south of Airport Road (confluence) further reduced the peak to $426 \mathrm{ft}^{3} / \mathrm{s}$ (fig. 20).

\section{Ground-Water Recharge}

Average annual recharge (bold type in fig. 7) varied spatially from $2.3 \mathrm{in} / \mathrm{yr}$ in the highly impervious commercial/industrial area (HRU 8) to $9.7 \mathrm{in} / \mathrm{yr}$ in the undeveloped North Fork areas (fig. 21a); the area-averaged overall recharge rate was $8.1 \mathrm{in} / \mathrm{yr}$. Effective imperviousness and soil infiltration were substantial factors in determining recharge. In addition, evapotranspiration, (as determined by plant cover, elevation, and aspect to the sun) also affected recharge differences between HRUs. For example, simulation calculations produced a more rapid melt over frozen soil on a south-facing slope (HRU 17) than on a north-facing slope (HRU 20). This rapid melt produced less infiltration than the slower melt on the non-south-facing slope (fig. 21a). HRU 17 had less slope and 20 percent less saturated conductivity than did HRU 20 (table 5); therefore, it is difficult to know precisely how much of the recharge difference resulted solely to aspect to the sun. In general, recharge from the nondeveloped HRUs were similar (table 5; fig. 21a). The monthly recharge rates were computed by summing the daily ground-water fluxes (bold type in fig. 7) from the individual HRUs. These rates were provided as input to the ground-water model and served as the linkage between the ground-water and surfacewater models (Hunt and Steuer, 2000). The coupling of the surface-water and ground water models illustrated the strong hydraulic connection between the North Fork of the Pheasant Branch and the Frederick Springs (fig. 22).

The monthly precipitation and recharge comparison (fig. 21b) shows that much of the recharge occurs during the winter and spring when snow is melting or during the fall when evapotranspiration is greatly reduced. Large amounts of precipitation fall during the summer; however, very little of this water infiltrates through the soil profile to provide recharge--most is lost to evapotranspiration. Often times recharge that left the upper Pheasant Branch Creek base flow area was greater than the streamflow (1994-98), whereas in 1993 it was similar to streamflow (fig. 12). Surface runoff in areas of minimal development is usually restricted to snowmelt periods (fig. 21b). 

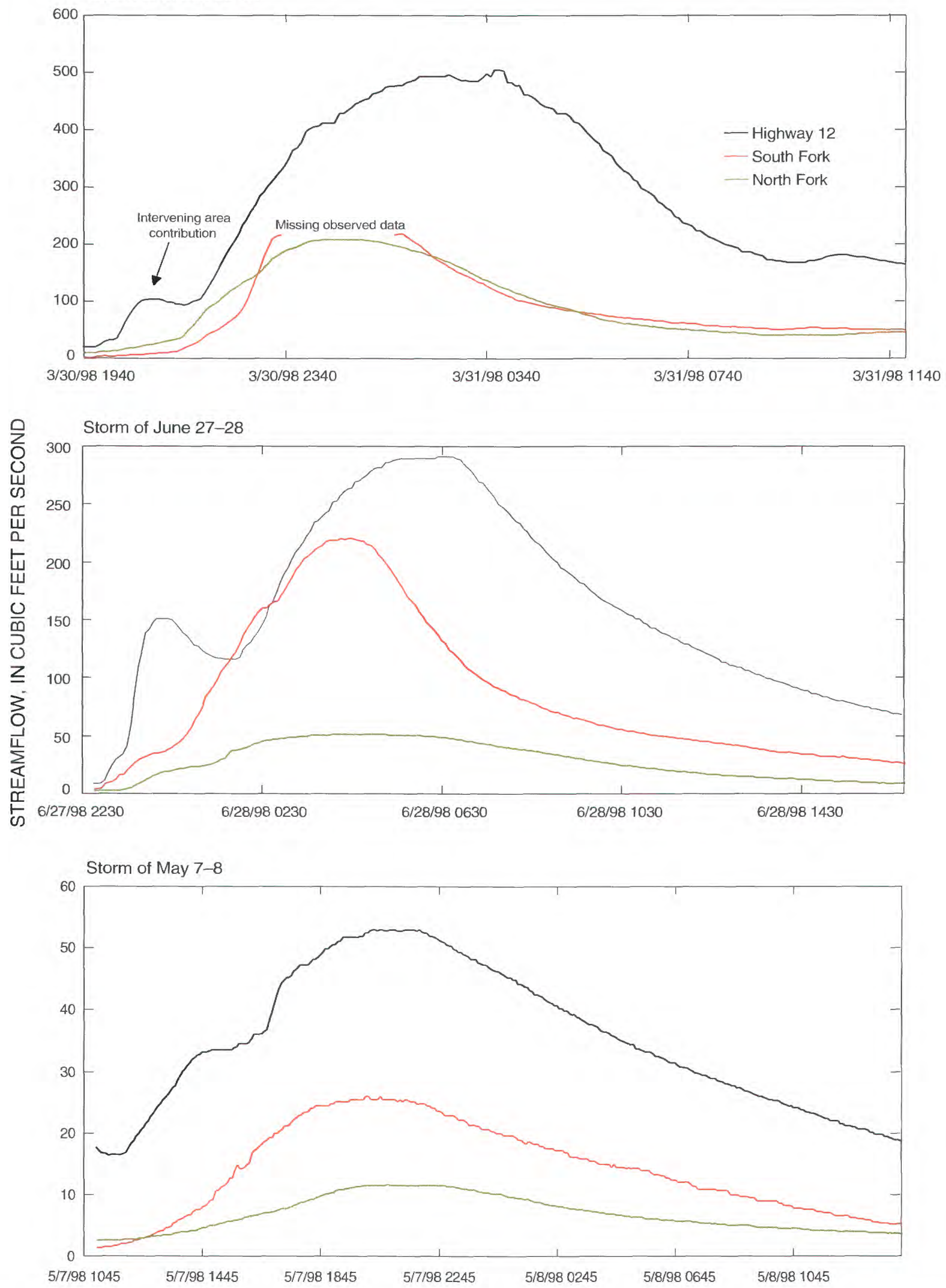

Figure 19. Observed Pheasant Branch Creek streamflow for the North and South Fork Basins and Highway 12, near Middleton, Dane County, Wis., for a range of storm events in 1998. 


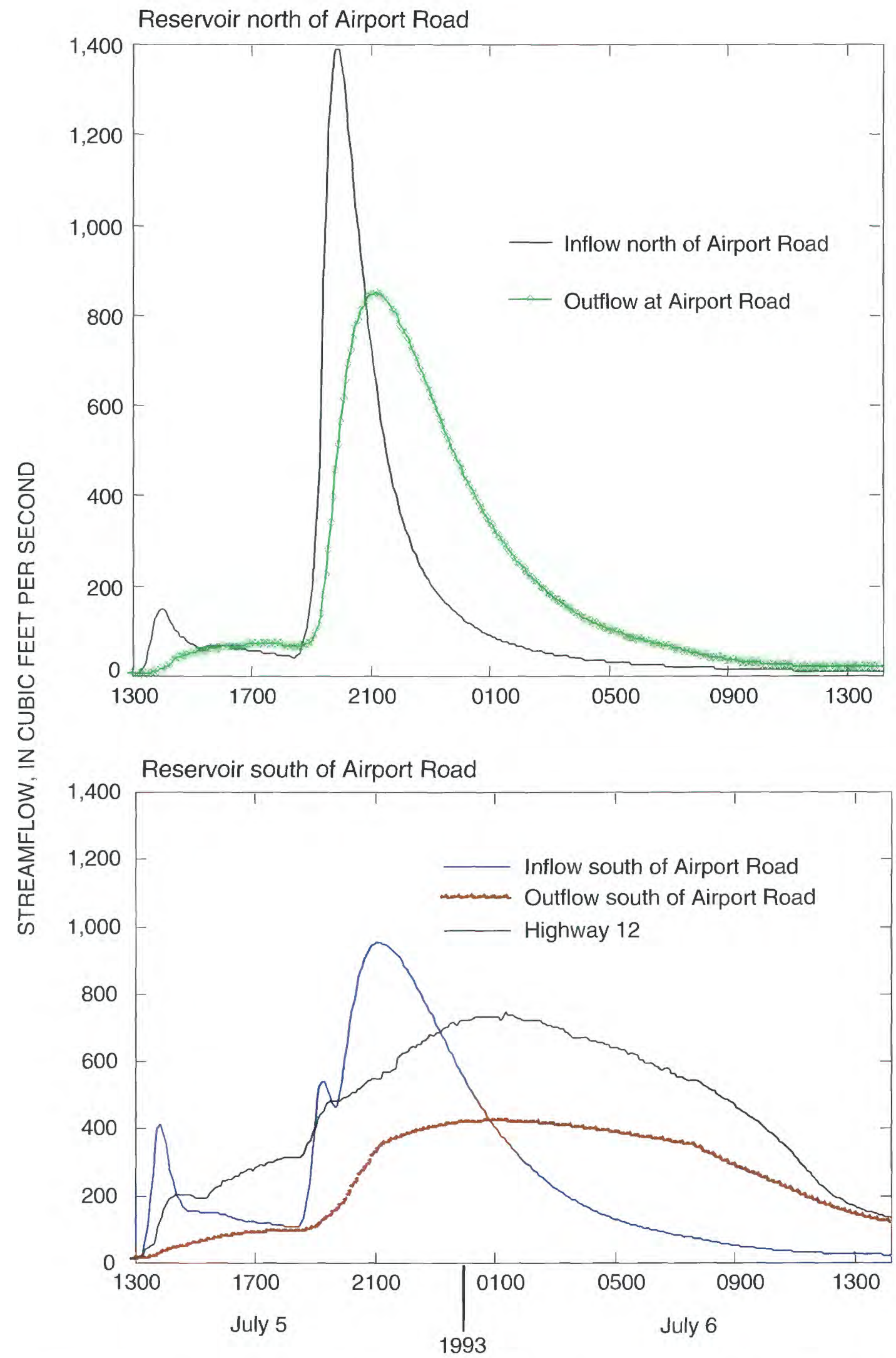

Figure 20. Simulated inflow and outflow for the flood-plain storage areas (reservoirs) near Airport Road, Middleton, Dane County, Wis., July 5-6, 1993. 


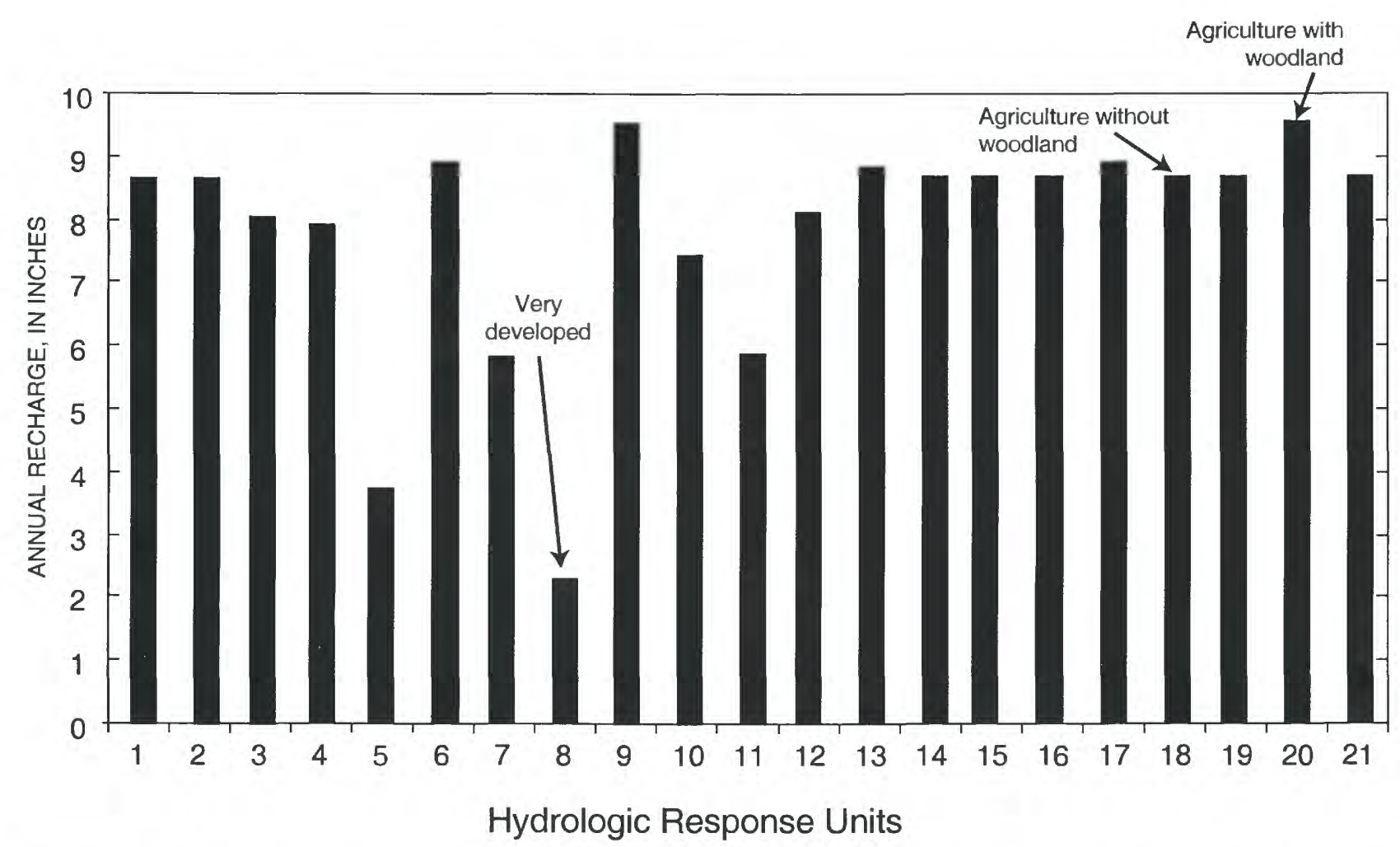

Figure 21a. Average annual computed recharge in all hydrologic response units in the Pheasant Branch Creek watershed model.

\section{EXAMPLE APPLICATIONS}

\section{Effect of Urbanization on Streamflow and Ground-Water Recharge}

The model was used to assess changes in streamflow hydrograph peaks, volumes, base flow, and recharge resulting from two urbanization development scenarios in the North Fork and intervening area basins. In both scenarios, the South Fork Basin was unchanged from current conditions.

In scenario A, development was assumed to be predominantly low-density residential with 5 to 10 percent commercial development along principal roadways (Krug and Goddard; 1986, p. 19). Designated flood plains were also assumed to remain in open-space use. This development scenario produced a range of effective imperviousness in the North Fork Basin of 15 to 18 percent and 18 to 34 percent in the intervening area basin. Overall effective imperviousness for the North Fork and intervening area basins were 16 percent and 25 percent, respectively. In two areas in the South Fork and intervening area basins, present-day imperviousness exceeded the "anticipated" imperviousness under this future "complete urbanization" scenario (Krug and Goddard, 1986).

In a second development scenario (B), the entire North Fork and intervening area basins were assumed to be developed with 50 percent commercial and 50 percent medium-density residential land use. This resulted in 60 percent connected imperviousness throughout the two subbasins.

Under present-day (1993-98) conditions, the average annual water budget for the overall basin (fig. 23) has much of the precipitation (35.2 in.) returning to the atmosphere in the form of evapotranspiration (23.9 in.). Flux to the regional ground-water system (6.0 in.) is a slightly larger component than streamflow (4.8 in.). The model determined daily streamflow for both scenarios A and B for Pheasant Branch Creek at Highway 12 for the period 1993 through 1998. A comparison of 22 streamflow hydrograph peaks for scenarios A and B to the hydrograph peaks for current land-use conditions is shown in figure 24. Summaries of the current waterbudget and changes for both scenarios for the period of 1993 through 1998 are also shown in figure 24 and table 7. 
Monthly precipitation

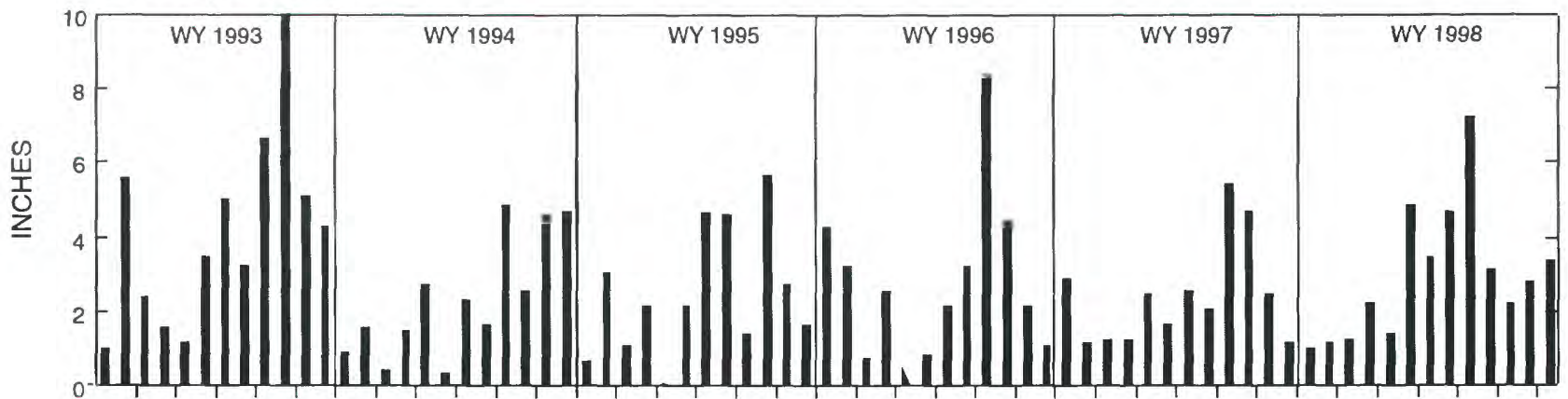

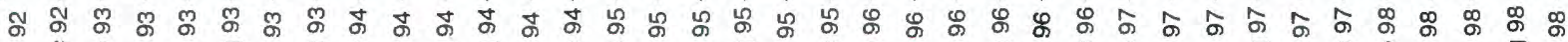

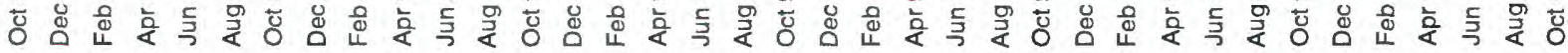

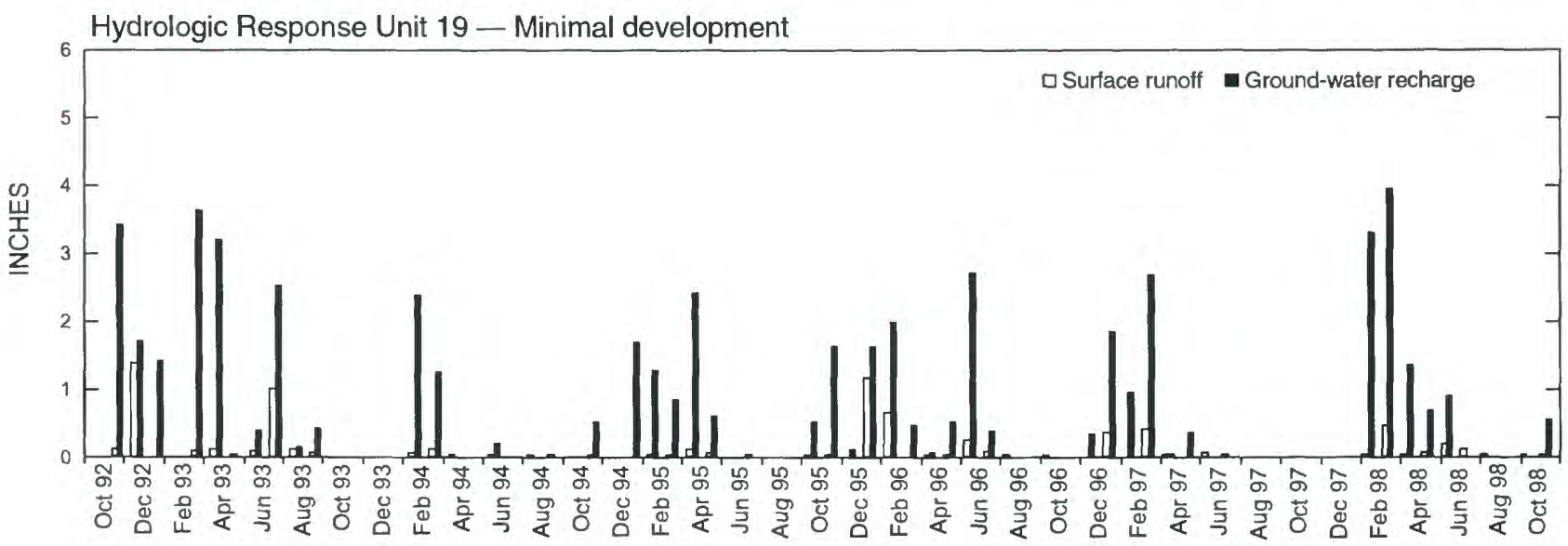

Hydrologic Response Unit 8 - Developed area with low-infiltration-rate soils

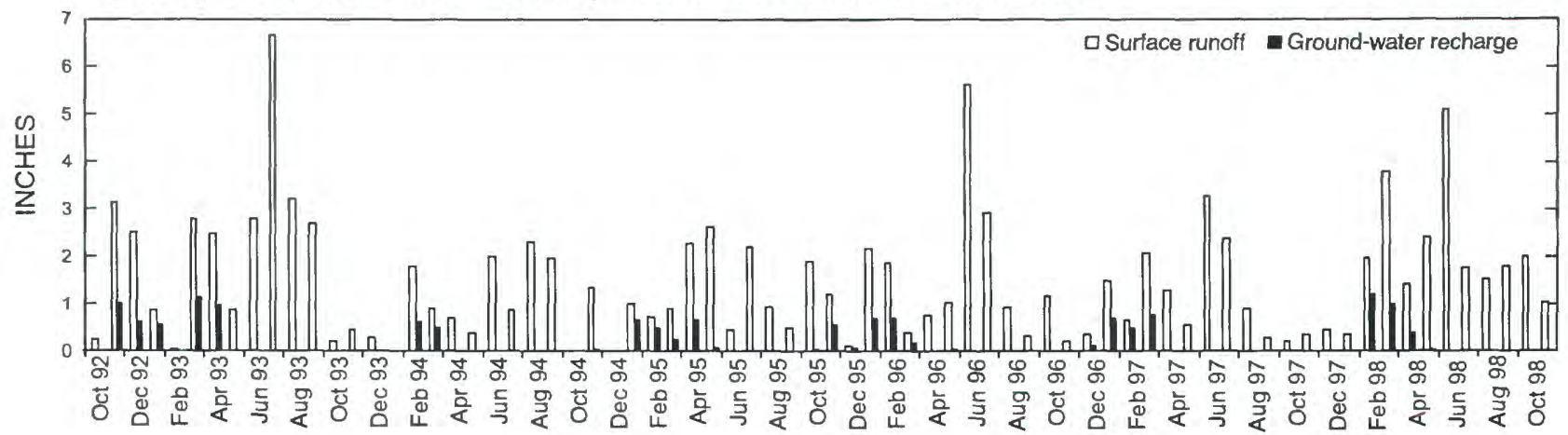

Figure 21b. Monthly precipitation, monthly recharge, and surface runoff as calculated for a nondeveloped (pervious) area and a developed, low-infiltration-rate (impervious) area, 1993-98. 


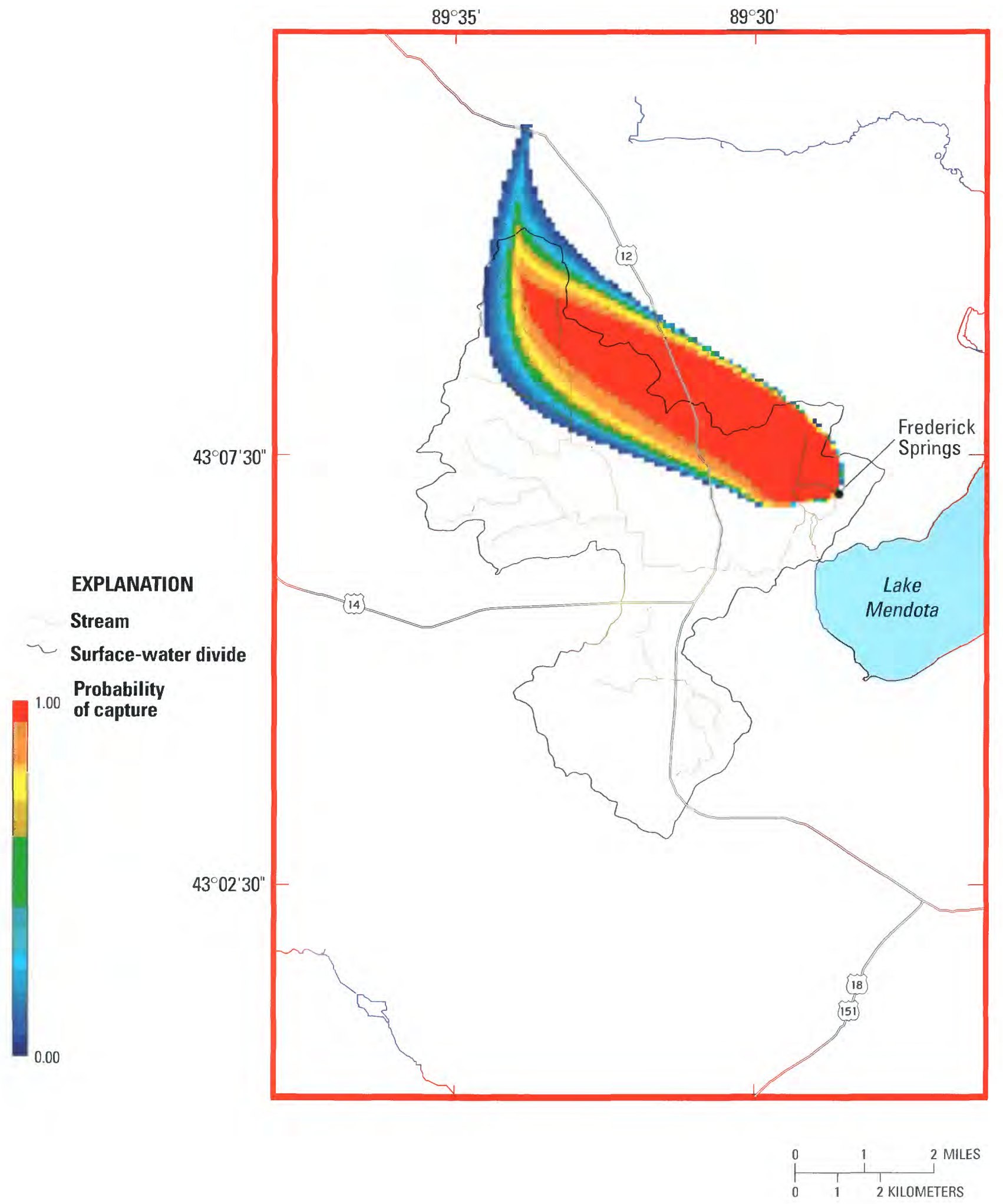

Figure 22. Simulated capture zone in the lower bedrock for Frederick Springs, Dane County, Wis. (from Hunt and Steuer 2000). 


\section{Average annual basin water budget (inches), water years 1993-98}

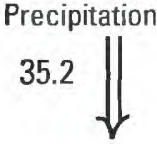

2.8

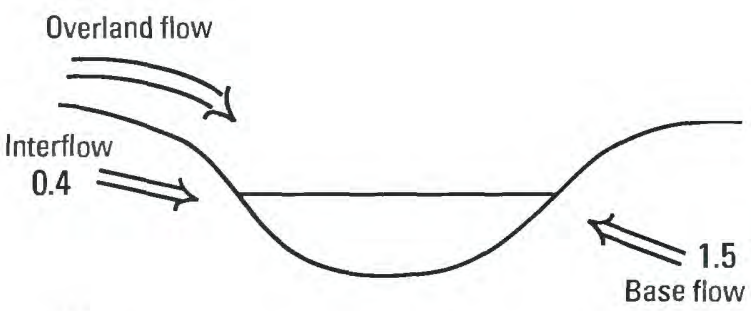

$\Downarrow 6.0$

Ground water to regional system (not captured by stream)

( $4.8 \mathrm{in.}$ over basin) Model simulated streamflow $\underline{5.2}$ cubic feet per second (4.9 in. over basin) Measured streamflow $\underline{5.3}$ cubic feet per second Marsh springs 2.1 cubic feet per second

Budget not balanced because of change in ground-water storage.

Figure 23. Simulated and observed average annual water fluxes, in inches, for present-day (1993-98) conditions, Pheasant Branch Basin upstream from Highway 12, Middleton, Dane County, Wis.

Under scenario A, mean annual streamflow increased by 53 percent, overland flow increased by 84 percent, and base flow decreased by 15 percent (fig. 24). As shown in figure 24 , streamflowhydrograph peaks were substantially increased for all events except the large July 1993 event, for which the peak increased by only 7 percent.

Scenario A also decreased recharge to the regional ground-water system by 10 percent. The monthly hydrologic response unit recharge rates were incorporated into the ground-water model (Hunt and Steuer, 2000) to assess development effects on the nearby Frederick Springs; discharge from the springs was estimated to be reduced by 5 percent.

Under scenario B, mean annual streamflow increased by 300 percent and overland flow increased by 458 percent. The ground-water model that used scenario $\mathrm{B}$ recharge rates as input predicted a lowered water table and zero base flow. As shown in figure 24, streamflow hydrograph peaks were dramatically increased for all events, including the large July 1993 event that increased 53 percent, from $750 \mathrm{ft}^{3} / \mathrm{s}$ to $1,150 \mathrm{ft}^{3} / \mathrm{s}$.

On average scenario $B$ decreased recharge to the regional ground-water system by 57 percent. The ground-water model simulated that flow from Frederick Springs would be reduced 26 percent from present-day conditions. The ground-water model, under either scenario A or B, did not take into account possible increases in ground-water pumpage and use because of urbanization. The 2-year recurrence interval is often used as a flow threshold above which channel scour occurs (Chang, 1992; Leopold and others, 1964). For 22 nonsnowfall events, this development scenario increased peak flow for 21 events to a level above the 2-year recurrence interval. In contrast, simulated peak flows from present-day development conditions exceeded this level for only 5 events.

\section{Example Detention-Pond Application}

A second model application assessed the potential of three detention sites to mitigate peak flows generated from urbanization scenario A. Without additional detention, during the large July 1993 event, urbanization scenario A increased the streamflow peak at the basin outlet by $54 \mathrm{ft}^{3} / \mathrm{s}$ ( 7 percent). Overall streamflow volume from the July 1993 event under scenario A was 1,800 acre-ft, an increase of 350 acre-ft from current land-use conditions. Channel flow volumes (acre-ft) for the July 1993 event under scenario A land-use conditions are detailed in figure 25. A substantial volume of water, 860 acre- $\mathrm{ft}$, was simulated to run off from the subbasin north of Airport Road (fig. 25), whereas the South Fork Basin was simulated to generate 490 acre- $\mathrm{ft}$ of water.

Topography (potential storage capacity) and soil characteristics in the North Fork Basin were examined in conjunction with simulated runoff volumes from the large July 1993 event (fig. 25) to identify locations at which runoff could be detained to reduce peak flow and possibly infiltrated to maintain ground-water recharge. Also identified were soil types with infiltration rates greater than $6 \mathrm{in} / \mathrm{hr}$ (Glocker and Patzer, 1978) in the subsurface soil profile. A preliminary examination identified three sites with the topography (storage potential), channel inflow volume, and subsoil infiltration to reduce the flood peak and to potentially infiltrate the additional 390 acre- $\mathrm{ft}$ of runoff resulting from the urbanization scenario. Those sites are: 

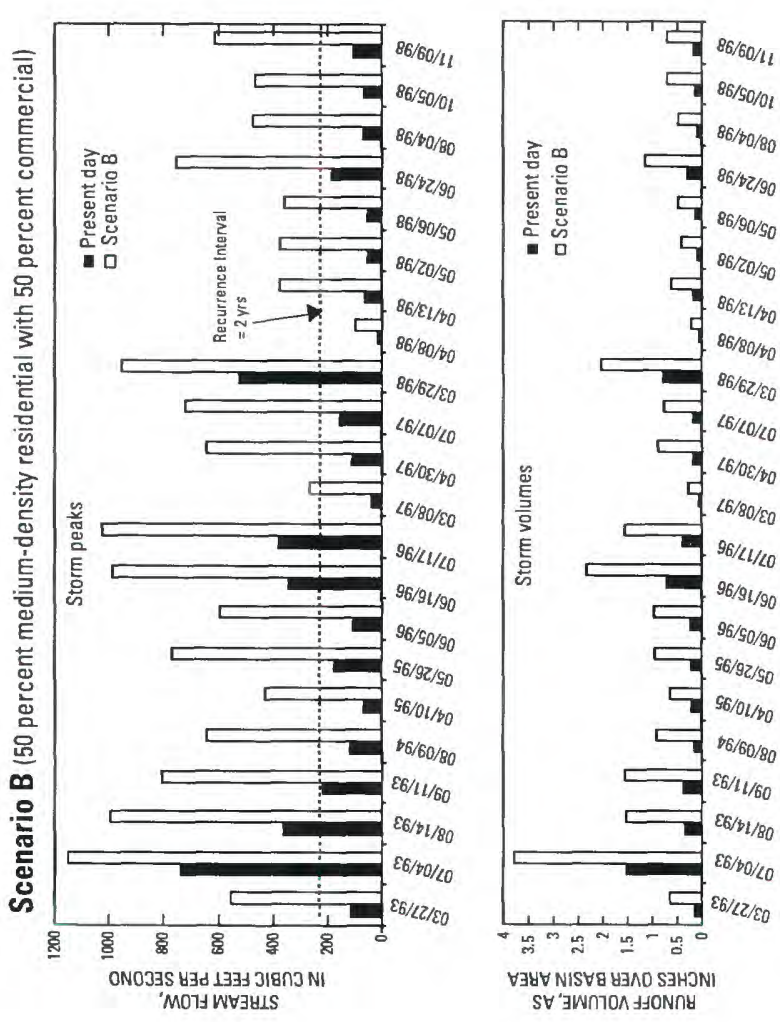

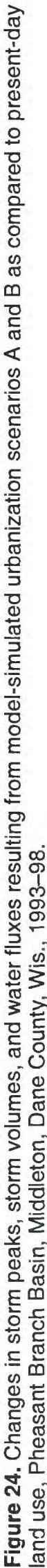
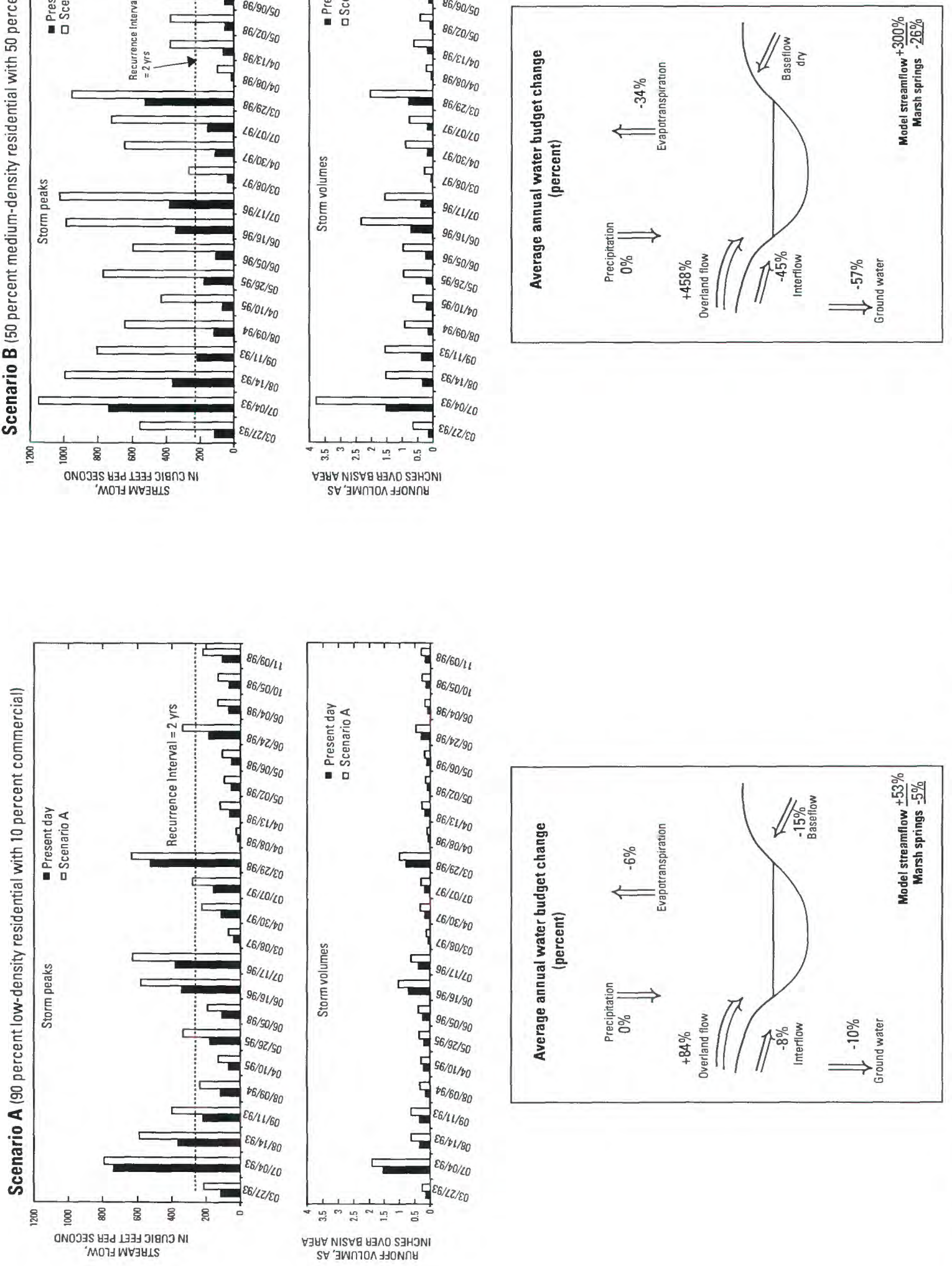

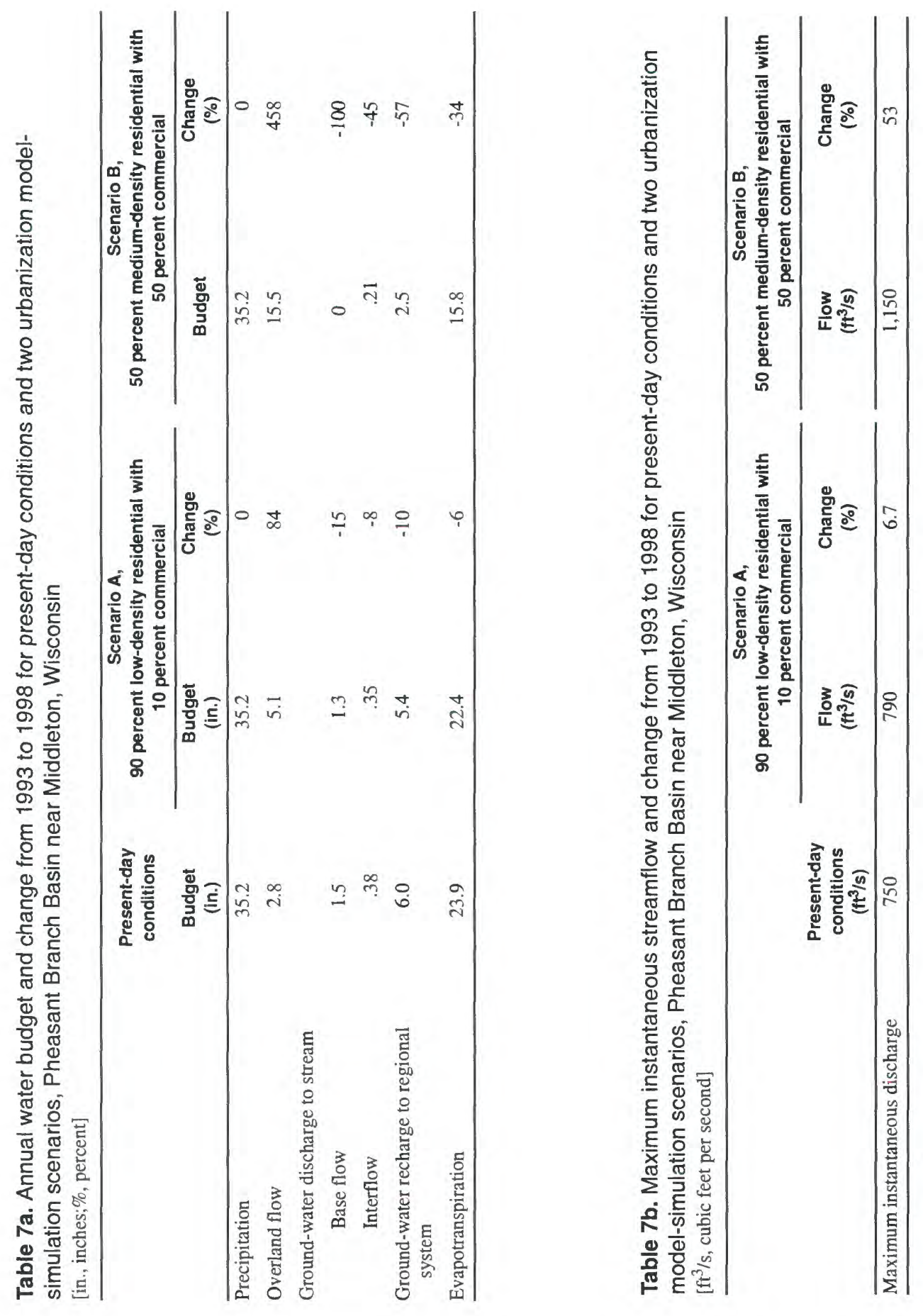


\section{EXPLANATION}

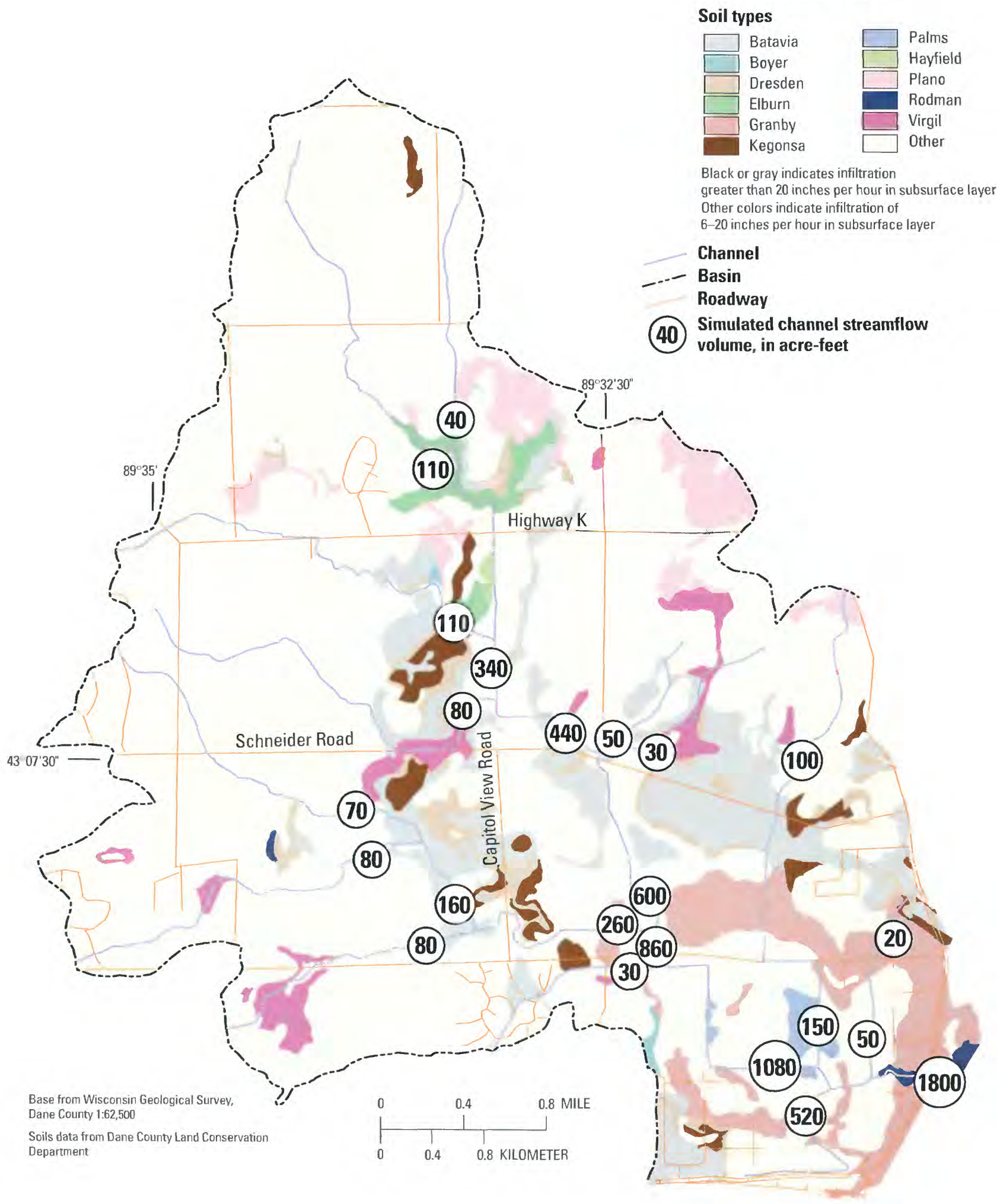

Figure 25. Selected North Fork subbasin soil types and simulated channel streamflow volumes (in acre-ft) for the July 4-13, 1993 high-flow event, scenario A, Middleton, Dane County, Wis. 


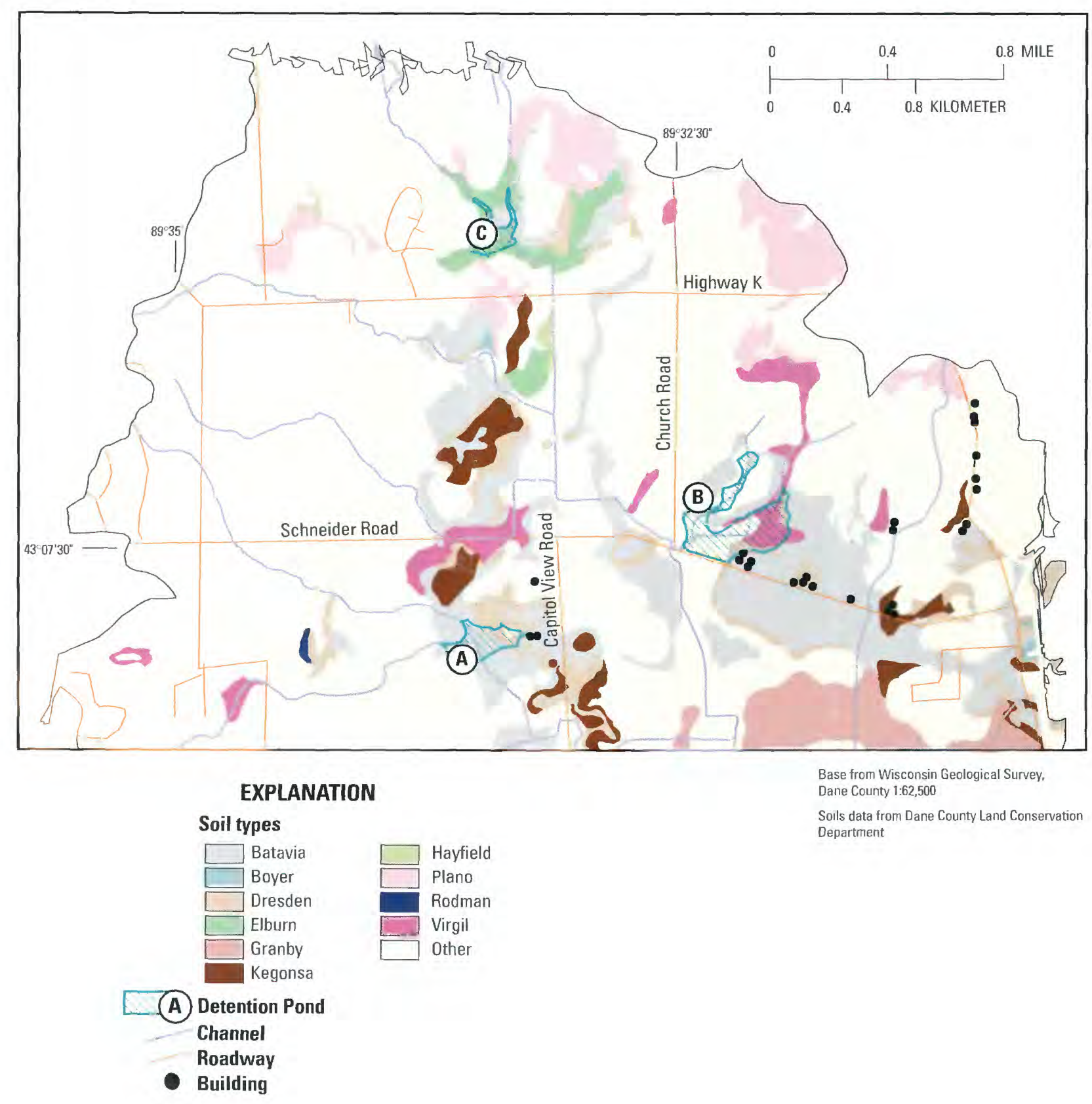

Figure 26. Location of high-infiltration-rate subsoils and three reservoirs used in the example application, Pheasant Branch Basin, Middleton, Dane County, Wis.

Site A - west of Capitol View Road - tributary volume of 150 acre-ft.

Site B - north of Schneider Road - tributary volume of 80 acre-ft.

Site C - north of Highway K-tributary volume of 150 acre-ft.

The three sites are shown in figure 26. Topographic maps, with 10-ft contour intervals, were used to establish depth-area-volume relations for the three sites. The outflow-storage relation for each site was estimated by assuming a 90-degree V-notch weir as the outlet structure.

These three storage areas reduced the July 1993 scenario A flood peaks at Highway $12 \mathrm{from} 790 \mathrm{ft}^{3} / \mathrm{s}$ to $702 \mathrm{ft}^{3} / \mathrm{s}$. This reduced peak is less than the calibrated model flood peak (present day-conditions) of $736 \mathrm{ft}^{3} / \mathrm{s}$. Of the three detention-ponds, the area upstream from Highway K had some of the greatest runoff volume (150 acre-ft; fig. 25) and the lowest storage capacity. The streamflow peak at this site was reduced from 
$454 \mathrm{ft}^{3} / \mathrm{s}$ to $87 \mathrm{ft}^{3} / \mathrm{s}$ (fig. 27). At peak storage, the reservoir surface area was approximately 15 acres with a maximum depth of $4.1 \mathrm{ft}$.

The three hypothetical detention ponds outfitted with 90-degree V-notch weirs did not reduce the scenario A flow peaks to the magnitude of present-day peaks (fig. 28) for all events. For most of the small events, the scenario A peaks were greater than presentday peaks. With a more elaborate outlet structures (compound weirs) or additional storage sites, reductions to present-day flood-peak magnitudes may be possible. Detention sites located upstream such as these would also have to compensate for increased runoff that is generated downstream.

The preceding analysis was based on flow routing only; the analysis did not include infiltration from the storage areas. It was not possible to assess pond infiltration within the existing PRMS model framework because the model does not account for infiltration or evaporation from storage areas; it solely routes the water through the reservoir. The high infiltration capacity of the subsurface soils near the three reservoir sites (figs. 2 and 26) indicates a potential for substantial infiltration of the detained water.

\section{SUGGESTIONS FOR FUTURE STUDY}

Precipitation data from the short-term rain gages were not incorporated directly into the modeling effort, primarily because the simulation was for 6 years and these data were collected for a period of 1-2 years. The PRMS framework does, however, allow spatial application of multiple precipitation data sets to the hydrologic response units. Future efforts could apply the spatially variable precipitation for the 1-2 years to determine whether model results are substantially improved. Doing so would provide guidance for future modeling efforts in this geographic region.

Operation of streamflow and precipitation gages at Highway 12 is independent from the modeling project; therefore, these gages are expected to remain in operation. The model could be updated with future precipitation and daily temperature data, and model output could again be compared to measured streamflow at Highway 12. Such a comparison would provide useful verification of the model. A substantial detention pond is planned to come online at the confluence of the North and South Forks in the next one or two years (Steve Grant, private consultant, oral commun., 1999). Future simulations will need to incorporate this detention pond.

The example detention-pond model application detailed the effects of three potential storage areas in reducing flood peaks and possibly enhancing infiltration. Detailed topographic and soils surveys, in addition to soil infiltration assessment, would be needed to accurately determine the potential to store and infiltrate runoff. The Water Resources Division of the USGS in Wisconsin is currently monitoring and assessing a designed treatment and infiltration system in the Black Earth Creek Basin. A similar future project is planned in the Pheasant Branch Basin. Results from these efforts should be used in conjunction with model results for the three detention and infiltration areas.

Lastly, the Pheasant Branch model detailed in this report could be expanded to include a sediment and phosphorus water-quality component. The data generated from this project could be used to calibrate such a model. It may be useful to convert the PRMS model developed in this project to the more recent Modular Modeling System, which allows writing custom modules to incorporate the most recent process research.

\section{SUMMARY AND CONCLUSIONS}

A deterministic rainfall-runoff model was developed to represent present-day hydrologic conditions in the upper Pheasant Branch Basin with an emphasis on the North Fork Basin. The model simulates the flux and storage of water in the surface, subsurface, and groundwater components of the watershed. This insight into the hydrologic processes allows better understanding of the hydrologic effects of future urbanization. Five techniques were employed to strengthen development of the rainfall-runoff model:

1. Flow-monitoring stations were established at two subbasins to isolate a predominantly agricultural (North Fork) and a predominantly urban (South Fork) subbasin. These supplemented a longer record ( 25 years) from a gaging station at the basin outlet (Highway 12).

2. Five short-term rain gages were installed to augment the longer-term precipitation record at the basin outlet. The resulting precipitation data were helpful in relating modeling results to observed data on a small-basin scale. 


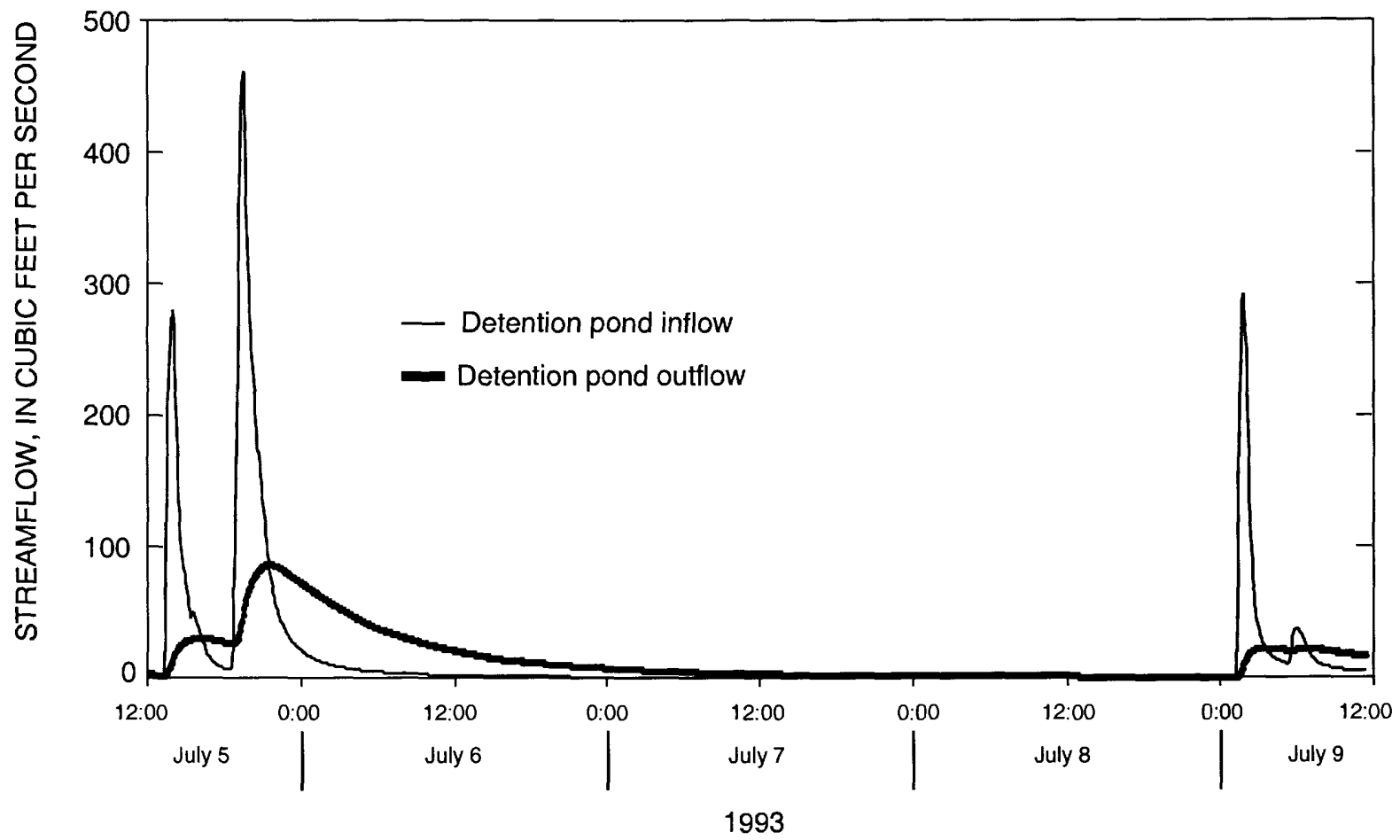

Figure 27. Simulated inflow and oufflow for the Highway K example detention pond for urbanization scenario A, Pheasant Branch Basin, near Middleton, Dane County, Wis. (no infiltration, 90 degree V-notch weir).

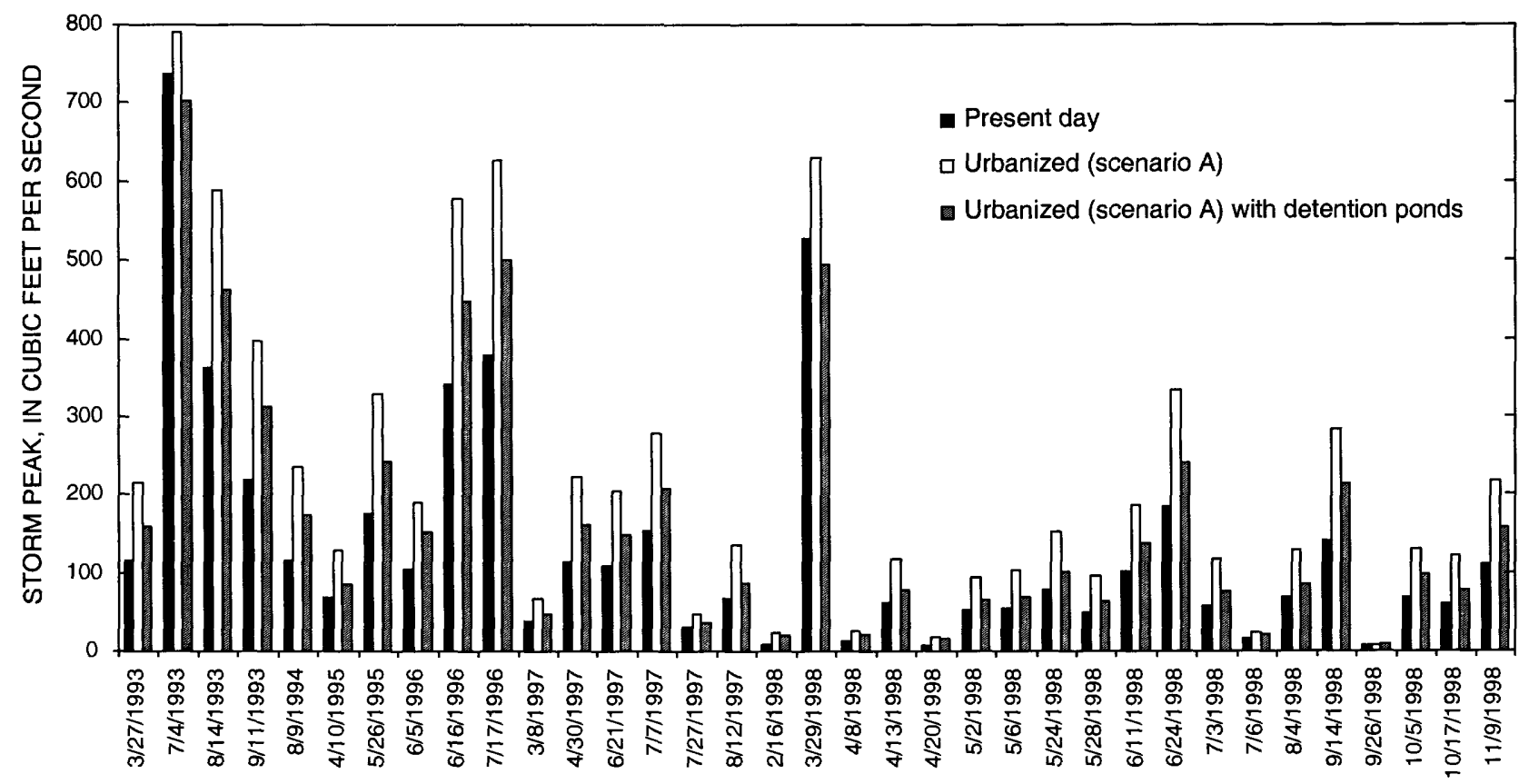

Figure 28. Simulated Pheasant Branch Creek flow peaks for present-day conditions, urbanization (scenario A), and urbanization tempered with three detention ponds with 90 degree V-notch weirs, Middleton, Dane County, Wis. 
3. Double-ring infiltrometer tests were done to assess relative infiltration rates between numerous combinations of land use and soil type.

4. Model representation of small subbasins were assessed qualitatively by means of reconnaissance after precipitation to determine the occurrence of flow in ditches and small channels. More than 175 observations, often including depth measurements, were made at 16 sites on the small tributaries (most were ephemeral) after precipitation events. During one event, qualitative measurements were made at 14 sites.

5. As a further effort to verify the model on a small subbasin scale, continuous stage sensors (15-min intervals) were placed to measure depth at the outlets of three small subbasins.

The calibrated model adequately simulated base flow (daily time step) and runoff response to rainfall (5-min time steps). The model accounted for 52 percent of the observed monthly streamflow variation for the 6 -year period. Generally, the model failed to simulate the timing of the snowmelt events (January through March). The model did, however, acceptably compute annual runoff volume, of which a substantial proportion resulted from snowmelt. If the snowmelt months of December through March are removed from simulations, the model accounts for 95 percent of the monthly streamflow variation and 92 percent of the daily streamflow variation. The mean annual runoff volume error for the 6-year simulation period was -2 percent (observed greater than simulated) and ranged from -17 percent to +16 percent.

For a range of events, the South Fork and North Fork streamflow hydrograph appears to peak nearly simultaneously with a traveltime to Highway 12 of 1-2 hours.

Under present-day conditions, the overall basin average annual water budget has much of the precipitation (35.2 in.) returning to the atmosphere in the form of evapotranspiration (23.9 in.). Flux to the regional ground-water system (6.0 in.) is a slightly larger component than streamflow (4.8 in.).

Resulting recharge rates from the calibrated surface-water model were subsequently linked to and improved a ground-water-flow model (Hunt and Steuer, 2000). Average annual recharge varied spatially from $2.3 \mathrm{in} / \mathrm{yr}$ in the highly impervious commercial/indus- trial area to $9.7 \mathrm{in} / \mathrm{yr}$ in the undeveloped North Fork Basin with an average overall recharge rate of $8.1 \mathrm{in} / \mathrm{yr}$. Much of recharge to the ground-water system originated from snowmelt. Most of the Frederick Springs recharge area is within the upper Pheasant Branch watershed, illustrating the strong connection between the North Fork of the Pheasant Branch and Frederick Springs.

Two urbanization scenarios were examined to assess changes in water-budget fluxes. In scenario A, development was assumed to be predominantly lowdensity residential with 5 to 10 percent commercial development along principal roadways. Under scenario A, mean annual streamflow increased by 53 percent, overland flow increased by 84 percent, and base flow decreased by 14 percent. In urbanization scenario B, the entire North Fork and intervening-area basins were assumed to be developed with 50 percent commercial and 50 percent medium-density residential land use. Storm runoff increased by more than 450 percent. The ground-water model, incorporating the scenario B recharge rates, simulated a lowered water table that would reduce base flow to zero and flow from Frederick Springs by 26 percent from present-day conditions. The ground-water model, under either scenario A or B, did not take into account possible increases in ground-water pumpage and use because of urbanization.

A second example application of the model evaluated locations of flood detention ponds and potential recharge areas that may mitigate the changes in flood peaks and ground-water recharge resulting from urbanization scenario A. The model was used to calculate runoff volumes from small subbasins. These volumes were, in turn, used to select and assess potential detention-pond sites. Three sites were examined. The three detention ponds reduced the scenario A streamflow peaks substantially but did not reduce all peaks to present-day magnitudes. Detention ponds were assumed to be outfitted with 90 -degree V-notch weirs. A more elaborate compound weir at the outlet could possibly reduce the peaks to present-day magnitudes. Further work, such as soil assessment and topographic surveying, would be required to determine the actual infiltration potential with a designed series of treatment and infiltration ponds.

From February 1998 through July 1998, waterquality samples were collected by use of stage-activated automated samplers. Median suspended-sediment concentrations were similar between the North and South Fork Basins (194 and $242 \mathrm{mg} / \mathrm{L}$, respectively); however, for other constituents, North Fork values were 
considerably higher: median phosphorus concentrations by 4 times ( 1.5 and $0.35 \mathrm{mg} / \mathrm{L})$, median ammonia concentrations by 13 times $(1.9$ and $0.14 \mathrm{mg} / \mathrm{L})$, and the phosphorus-to-sediment ratio by more than 6 times ( 21 and $3.1 \mathrm{mg} / \mathrm{g}$ ). On a unit-area basis the commercial/industrial intervening area was the dominant subbasin for all the fluxes--generated water volume, sediment and phosphorus loads-perhaps because of less permeable soils in the intervening area or a lack of detention or storage areas in the intervening area as contrasted with designed storage available in the South Fork Basin.

\section{REFERENCES}

Bouwer, H., 1986, Intake rate-cylinder infiltrometer, methods of soil analysis part 1. physical and mineralogical methods: American Society of Agronomy-Soil Science Society of America, p. 825-844.

Chang, H.H., 1992, Fluvial processes in river engineering: Melbourne, Florida, Krieger Publishing Co., 432 p.

Dunker, J.J., and Melching, C.S., 1998, Regional rainfallrunoff relations for simulations of streamflow for watersheds in Du Page County, Illinois: U.S. Geological Survey Water-Resources Investigations Report 98-4035, $80 \mathrm{p}$.

Farnsworth, R.K., and Thompson, E.S., 1982, Mean monthly, seasonal, and annual pan evaporation for the United States: National Oceanic and Atmospheric Administration Technical Report NWS 34, 85 p.

Glocker, C.L., and Patzer, R.A., 1978, Soil Survey of Dane County, Wisconsin: U.S. Department of Agriculture Soil Conservation Service, 193 p.

Graczyk, D.J., Walker, J.F., Greb, S.R., and Owens, D.W., 1993, Evaluation of nonpoint-source contamination, Wisconsin—selected data for 1992 water year: U.S. Geological Survey Open-File Report 93-630, 48 p.

Green, H.W., and Ampt, G.A., 1911, Studies of soil physics, 1-Flow of air and water through soils: Journal Agricultural Research, v. 4, p. 1-24.

Hamon, W.R., 1961, Estimating potential evapotranspiration: Proceedings of the American Society of Civil Engineers, Journal of Hydraulic Division, v. 87, no. HY3, p. $107-120$.

Holmstrom, B.K., and others, 1999, Water resources data, Wisconsin, water year 1999: U.S. Geological Survey Water-Data Report WI-99-1, 578 p. 1998, Water resources data, Wisconsin, water year 1998: U.S. Geological Survey Water-Data Report WI-98-1, $508 \mathrm{p}$.

Hunt, R.J., and Steuer, J.J., 2000, Delineating the recharge for Frederick Springs, Dane County, Wisconsin: U.S. Geo- logic Survey Water-Resources Investigations Report 00-4172, 33 p.

Krohelski, J.T., Bradbury, K.R., Hunt, R.J., and Swanson, S.K., 2000, Numerical simulation of ground-water flow in Dane County, Wisconsin: Wisconsin Geological and Natural History Survey Bulletin 98, 44 p.

Krug, W.R., and Goddard, G.L., 1986, Effects of urbanization in streamflow, sediment loads, and channel morphology in Pheasant Branch Basin near Middleton, Wisconsin: U.S. Geological Survey Water-Resources Investigations Report 95-4068, 82 p.

Leavesley, G.H., Lichty, R.W., Troutman, B.M., and Saindon, L.G., 1983, Precipitation-runoff modeling systemUser's manual: U.S. Geological Survey WaterResources Investigations Report 83-4237, 207 p.

Leopold, L.B., Wolman, G.M., and Miller, J.P., 1964, Fluvial processes in geomorphology: Denver Publication, Inc., $522 \mathrm{p}$.

Maher, L.J., 1999, The early history of the Pheasant Branch watershed-Appendix 3, unpublished report from the North Fork Pheasant Branch Watershed committee: http://www.geology.wisc.edu/ maher/ pheasant_branch.html.

Nash, J.E., and Sutcliffe, J.V., 1970, River flow forecasting through conceptual models-Part 1-A discussion of principles: Journal of Hydrology, v. 10, p. 282-290.

Obled, Charles, and Rosse, B.B., 1977, Mathematical models of a melting snowpack at an index plot: Journal of Hydrology, no. 32, p. 139-163.

Risley, J.C., 1994, Use of a precipitation-runoff model for simulating effects of forest management on streamflow in 11 small drainage basin, Oregon Coast Range: U.S. Geological Survey Water-Resources Investigations Report 93-4181,61 p.

Sutherland, P.E., 1995, Methodology for estimating the effective impervious area of urban watersheds-watershed protection techniques: Center for Watershed Protection, v. 2.1, p. $282-287$.

Tangborn, W.V., 1978, A model to predict short-term snowmelt runoff using synoptic observations of streamflow, temperature, and precipitation in Colbeck, S.C., and Ray, M., eds., Modeling of snow cover runoff, Hanover, New Hampshire, 1978 [Proceedings]: U.S. Army Corps of Engineers, Cold Region Research and Engineering Laboratory, p. 414-426.

Thompson, E.S., 1976, Computation of solar radiation from sky cover: Water Resources Research, v. 12, no. 5, p. $859-865$. 



\section{APPENDIX}




\section{APPENDIX A}

The simulation period for the calibrated model detailed in this report concluded on September 30, 1998. A separate investigative project required runoff and channel hydrographs for the South Fork Basin for the period October 1, 1998, through September 30, 2000. Therefore, the entire Pheasant Branch model (basin outlet at Highway 12) was updated. Maximum daily temperature, minimum daily temperature, 5-min and daily precipitation from the Highway 12 rain gage, and daily precipitation from the Truax Airport during the winter period were the new data used to rerun the model. No changes were made to the model parameters.

From May 31 through June 1, 2000, a 5.45-in. precipitation event, coupled with wet antecedent soil conditions, produced the largest recorded instantaneous flow peak, $902 \mathrm{ft}^{3} / \mathrm{s}$, observed in the 26-year Pheasant Branch flow record. The model did well in simulating this large event (fig. A-1). The model also indicated that the two flood-plain storage areas upstream and down- stream of Airport Road substantially reduced the runoff peak originating from the northern basin. The model also appropriately represented a much smaller event (fig. A-2).

For this 2-year verification period, the model performed well in representing the observed daily streamflow (fig. A-3). Computed on a daily basis, the model represented 90 percent of the variation (model-fit efficiency equal to 0.90 ). With removal of the snowmelt months (December through March) the model-fit efficiency is increased to 0.92 .

Observed and simulated annual data for the verification period are listed in appendix A-table 1 for the basin outlet (Highway 12). The annual runoff volume errors ( -18 and 4 percent) for the 2-year period (1999-2000) were similar to the error observed during the original 6-year simulation period (1993-98). The overall error for the 1993 through 2000 period was -3 percent (observed was greater than simulated). 


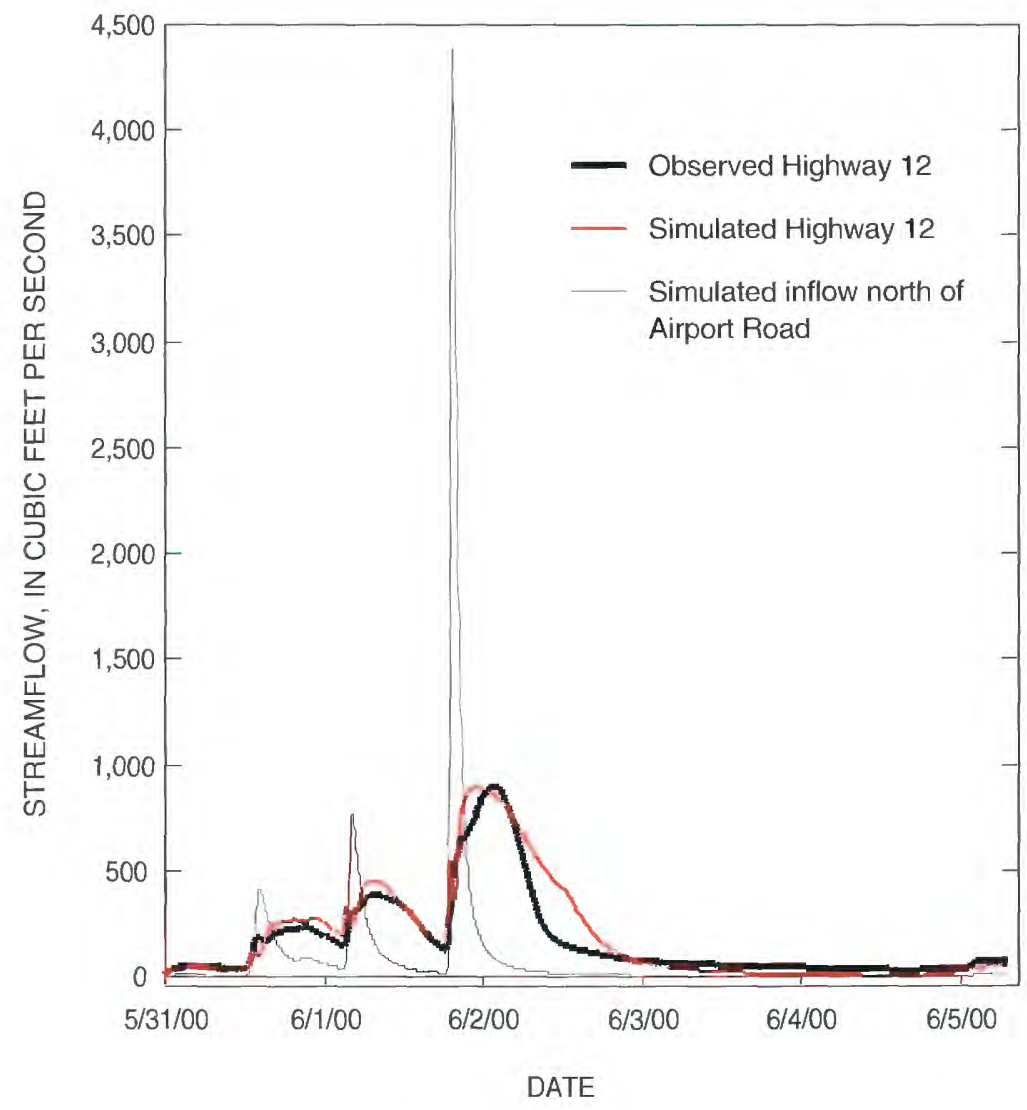

Figure A-1. Observed and simulated streamflow for Pheasant Branch Creek at Highway 12, Middleton, Dane County, Wis., May 31 through June 3, 2000.

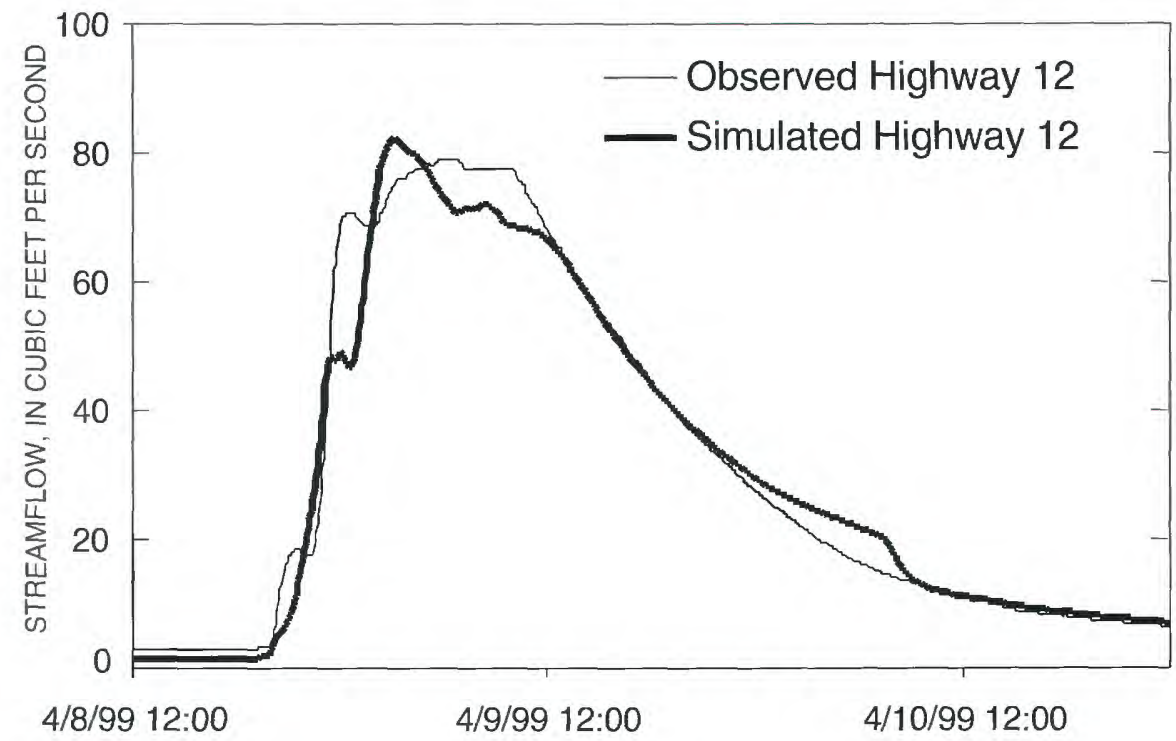

Figure A-2. Observed and simulated streamflow for Pheasant Branch Creek at Highway 12, Middleton, Dane County, Wis., April 8 through April 10, 1999. 

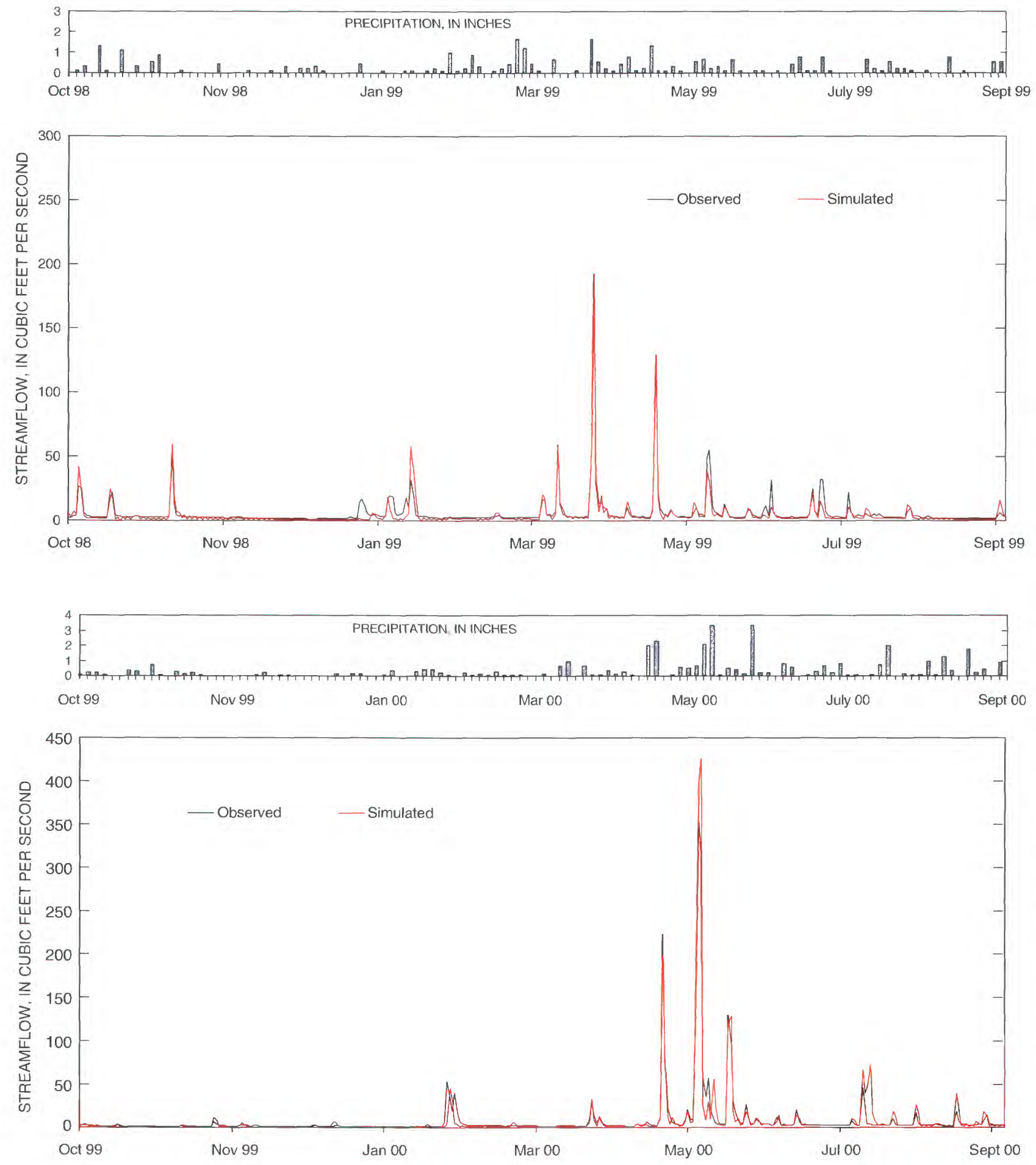

Figure A-3. Observed precipitation and observed and simulated daily streamflow for Pheasant Branch Creek at Highway 12 , Middleton, Dane County, Wis., for water years 1999-2000. 
Table A-1. Observed and simulated runoff data for verification period 1999-2000

[Sim., simulated value, in inches; Obs, observed value, in inches; difference in inches (diff) = Sim-Obs; difference in percent (percent diff) $=100 x([\mathrm{Sim}-\mathrm{Obs}] / \mathrm{Obs})]$

\begin{tabular}{cccccc}
\hline Water Year & Precip & Obs & Sim & Diff & Percent diff \\
\hline 1993 & 50.3 & 8.5 & 8.0 & -0.5 & -6 \\
1994 & 28.7 & 4.3 & 3.7 & -.6 & -14 \\
1995 & 30.3 & 2.7 & 3.1 & .4 & 16 \\
1996 & 34.3 & 4.7 & 5.3 & .6 & 13 \\
1997 & 29.7 & 4.4 & 3.7 & -.8 & -17 \\
1998 & 37.8 & 4.6 & 4.9 & .4 & 8 \\
Total & 211.1 & 29.2 & 28.7 & -.5 & -2 \\
\hline \multirow{2}{*}{1999} & Verification period-October 1, 1999 through September 30, 2000 & \\
\hline 2000 & 32.9 & 4.8 & 3.9 & -.8 & -18 \\
Total & 39.6 & 6.2 & 6.4 & .2 & 4 \\
\hline
\end{tabular}


8 Printed on recycled paper 

